\title{
DEFLECTIONS OF COMPOSITE BEAMS WITH WEB OPENINGS
}

\author{
By \\ Manuel A. Benitez \\ David Darwin \\ Rex C. Donahey
}

A Report on Research Sponsored by

THE UNIVERSITY OF KANSAS STRUCTURAL ENGINEERING AND MATERIALS LABORATORY

UNIVERSITY OF KANSAS

LAWRENCE, KANSAS

June 1990 


\begin{abstract}
Procedures for calculating the deflections of composite beams with web openings are described. Deflections are calculated using the stiffness method of matrix analysis. Unperforated sections of a beam are modeled using uniform beam elements. Web openings are modeled using beam elements connected by rigid links. Moments of inertia for unperforated sections are calculated considering partial composite action. The top tee over an opening is modeled: 1) neglecting composite action, 2) including composite action, and 3) including composite action at the high moment end only. Models with both the effective moment of inertia and lower bound moment of inertia are studied. The effects of shear deformation are investigated. Calculated deflections are compared to test data and the performance of the various models is evaluated. A case study of hypothetical beams with web openings is used to develop design recommendations for calculating total deflection and deflection across an opening. A relationship between the total deflections of beams with and without web openings is established. Equations are also developed for predicting the deflection across an opening.

The study shows that in most cases, a single web opening often has little effect on the deflection of a composite beam. However, there are important cases where the effect can be significant. Generally, the effects of an opening and of shear deflections will be of the same order. Ignoring both the web opening and shear deformation can lead to significant error. The matrix stiffness method provides a reasonable estimate of total deflection and deflection across the opening.
\end{abstract}




\section{INTRODUCTION}

Most steel buildings use composite members consisting of a concrete deck integrally connected to a steel section. Mechanical shear connectors are provided at the interface of the concrete and steel to resist the horizontal shear forces which develop due to bending. The depth of the floor system for such buildings may be reduced if a web opening can be introduced in the steel section through which utilities are passed. The decreased depth of the floor system can result in a reduced building height and overall cost savings.

The introduction of a web opening may have a significant effect on the deflections of a composite beam. A web opening will reduce the stiffness of the beam at the opening and result in increased deflections, as well as a differential deflection across the opening. In most cases, the influence of a single web opening is small. For those cases however, where the increase in the deflections is unacceptable, a procedure capable of accurately predicting the deflections is needed.

A number of procedures have been developed to calculate the deflections for flexural members with web openings. These procedures specifically address steel beams (McCormick 1972, Dougherty 1980), and one method specifically covers composite members (Donahey and Darwin 1986, Donahey 1987). The first two procedures require the calculation of the deflection due to the web opening; the total deflection is then calculated by adding this deflection to the deflection of a beam without an opening. The method developed for composite members (Donahey and Darwin 1986, Donahey 1987), which can also be used for steel members, is used to directly calculate the total deflections of members with web openings.

Web openings reduce the stiffness of a member at the opening by: 1) lowering the gross moment of inertia at the opening, 2) eliminating strain compatibility between the top and bottom tees (regions above and below the opening), and 3) reducing the cross sectional area available for carrying shear. The lower gross moment of inertia results in increased curvature at op nings subjected to bending. The elimination of strain compatibility and the loss of available material for carrying shear results in differential or Vierendeel deflections across an opening subjected to shear. 
To correctly calculate the deflection of a beam, equilibrium, compatibility, and material properties must be satisfied throughout the span. A complete analysis will include both bending and shear deformations. Although classical methods incorporating all of these requirements can be developed, it is possible to obtain equivalent results (within the accuracy of any assumptions) using matrix analysis methods. The matrix method is particularly attractive since it can automatically enforce compatiblity of displacements and rotations at the ends of the opening.

This report describes procedures for finding the deflections of composite beams with web openings. The methods represent an extension of the work done by Donahey and Darwin (1986). Modeling assumptions are verified by comparing experimental data with matrix analysis results. Recommendations for the practical application of the matrix analysis are made. The method is used in a case study of hypothetical beams with web openings. Based on the study, a design aid for deflection analysis of composite beams with web openings is developed. Matrix analysis is also used to develop equations for the deflection across a web opening.

\section{ANALYSIS PROCEDURES}

The analysis procedures used in this study are described in this section. Element stiffness matrices are developed to represent both the unperforated sections of the beam and the region around the web opening.

A composite beam with a web opening is shown in Fig. 1. The opening is of length $a_{0}$ and depth $h_{0}$. The beam is of span length $L_{s}$, and the opening center line is located at distance $\mathrm{L}_{\mathrm{o}}$ from the center line of the support. Section dimensions are given in Fig. $1 b$.

Deflections are calculated using the stiffness method of matrix analysis. The top and bottom tees at an opening, as well as the nonperforated sections adjacent to the opening, are modeled using standard 6 degree of freedom (DOF) beam elements. The local element stiffness matrix, $\left[\mathrm{K}_{\mathrm{e}}\right]$, is given as (Cook 1981): 


$$
\left[\mathrm{K}_{\mathrm{e}}\right]=\frac{\mathrm{E} \beta}{\mathrm{L}}\left[\begin{array}{cccccc}
\frac{\mathrm{A}}{\beta} & 0 & 0 & \frac{-\mathrm{A}}{\beta} & 0 & 0 \\
& 1 & \frac{\mathrm{L}}{2} & 0 & -1 & \frac{\mathrm{L}}{2} \\
& & \frac{\mathrm{L}^{2}}{3}+\eta & 0 & \frac{-\mathrm{L}}{2} & \frac{\mathrm{L}^{2}}{6}-\eta \\
& & \frac{\mathrm{A}}{\beta} & 0 & 0 \\
& & & & 1 & \frac{-\mathrm{L}}{2} \\
& & & & & \frac{\mathrm{L}^{2}}{3}+\eta
\end{array}\right]
$$

in which $E=$ modulus of elasticity, $\beta=\mathrm{I} /\left(\mathrm{L}^{2} / 12+\eta\right), \eta=E \mathrm{I} /\left(\mathrm{A}_{\mathrm{y}} \mathrm{G}\right), \mathrm{A}_{\mathrm{y}}=$ effective shear area, $A=$ gross transformed area for axial deformations, $L=$ element length, and $I=$ moment of inertia of the transformed section.

The element is capable of incorporating shear deformations, as well as axial and bending deformations. Shear deformations can be neglected by setting $\eta=0$. This is equivalent to assuming $A_{y}=\infty$.

$\left[\mathrm{K}_{e}\right]$ is derived considering bending of a beam about its own neutral axis. For the nonperforated sections of the beam, the local and global DOF are coincident. Therefore, for the nonperforated sections of the beam, the local element stiffness matrix, $\left[\mathrm{K}_{\mathrm{e}}\right]$, and the global element stiffness matrix, $\left[\mathrm{K}_{\mathrm{g}}\right]$, are identical.

At an opening, the neutral axes of the tees and the adjacent nonperforated section are not coincident. Therefore, the local DOF for the top and bottom tees do not correspond to the global DOF for the structure. By assuming that the webs adjacent to the opening are infinitely rigid, however, the nodes of the individual tees can be connected to the nodes of the nonperforated section by rigid links. The rigid links relate the local DOF for the top and bottom tees to the global DOF at the ends of the opening.

A beam element with 2 rigid links is shown in Fig. 2. The local and global $x$ axes are parallel, and eccentricities exist in both the $\mathrm{x}$ and $\mathrm{y}$ directions. The local DOF are given by : 


$$
\left\{u_{1}\right\}^{T}=\left\lfloor\begin{array}{llllll}
u_{11} & v_{11} & \theta_{11} & u_{12} & v_{12} & \theta_{12}
\end{array}\right]
$$

and the global DOF are

$$
\left\{u_{g}\right\}^{T}=\left\lfloor\begin{array}{llllll}
u_{g} 1 & v_{g 1} & \theta_{g 1} & u_{g 2} & v_{g 2} & \theta_{g 2}
\end{array}\right.
$$

An eccentricity transformation, $[\delta]$, is used to relate the local DOF and the global DOF:

$$
[\delta]=\left[\begin{array}{cccccc}
1 & 0 & -\mathrm{e}_{\mathrm{y} 1} & 0 & 0 & 0 \\
& 1 & \mathrm{e}_{\mathrm{x} 1} & 0 & 0 & 0 \\
& & 1 & 0 & 0 & 0 \\
& & & 1 & 0 & -\mathrm{e}_{\mathrm{y} 2} \\
& & & & 1 & \mathrm{e}_{\mathrm{x} 2} \\
& & & & & 1
\end{array}\right]
$$

in which $e_{\mathrm{y} 1}$ and $e_{\mathrm{y} 2}$ are the local $\mathrm{y}$ eccentricities and $\mathrm{e}_{\mathrm{x} 1}$ and $\mathrm{e}_{\mathrm{x} 2}$ are the local $\mathrm{x}$ eccentricities at nodes 1 and 2, respectively.

The global stiffness matrix, $\left[\mathrm{K}_{\mathrm{g}}\right]$, for an eccentric beam element is given by:

$$
\left[\mathrm{K}_{\mathrm{g}}\right]=[\delta]^{\mathrm{T}}\left[\mathrm{K}_{\mathrm{e}}\right][\delta]
$$

The coordinate transformation given above is derived for a beam element with eccentricities at both ends. For some models it is necessary to use two beam elements to represent the top tee. For these cases, the interior node at the center line of the opening must be condensed out of the local stiffness matrix for the top tee prior to the coordinate transformation.

The global stiffness matrices for the individual tees can be combined to form a web opening element. The web opening element consists of top and bottom tee elements 
connected by four rigid links (Fig. 3). Nodes 1 and 2 of the web opening element are located so that the positive global coordinate axis, $\mathrm{x}_{\mathrm{g}}$, passes through the nodes. The nodes of the web opening element are connected to the ends of the top and bottom tees by rigid links of length $l_{t}$ and $l_{b}$, respectively. Local eccentricities $e_{x 1}=e_{x 2}=0$ for both the top and bottom tees, while $e_{y 1}=e_{y 2}=l_{t}$ for the top tee and $e_{y 1}=e_{y 2}=-1_{b}$ for the bottom tee. The global stiffness matrix for the web opening element, $\left[\mathrm{K}_{\mathrm{g}}\right]_{\mathrm{wo}}$, is the sum of the global stiffness matrices $\left[\mathrm{K}_{\mathrm{g}}\right]$ for the individual tees. The global stiffness matrix for the web opening element can then be added directly to the global structure stiffness matrix, which consists of uniform beam elements on either side of the web opening. The structure used in the analyses is shown in Fig. 4.

\section{Modeling Assumptions}

The element stiffness matrices discussed above are a function of the material properties and certain section parameters. The modeling assumptions used to calculate the element matrices for both the perforated and unperforated sections of the beam are now discussed.

Moment of inertia for unperforated sections of beam.-- In this study, the moments of inertia for the unperforated sections of a beam are computed using either the effective moment of inertia, $I_{\text {eff }}$ (AISC 1989), or the lower bound moment of inertia, $I_{1 b}$ (AISC 1986). For both $I_{\text {eff }}$ and $I_{l b}$, the concrete slab is transformed into an equivalent steel area and is assumed to act compositely with the steel section.

For models using $\mathrm{I}_{\mathrm{eff}}$, the concrete deck is replaced by an equivalent steel area based on the modular ratio $E_{\text {stee }} / E_{\text {concrete }} . I_{\text {eff }}$ is calculated using the provisions of Part 5 of the AISC Manual of Steel Construction (AISC 1989) and is given by:

$$
\begin{gathered}
\mathrm{I}_{\text {eff }}=\mathrm{I}_{\mathrm{s}}+\sqrt{\left(\mathrm{V}_{\mathrm{h}}^{\prime} / \mathrm{V}_{\mathrm{h}}\right)}\left(\mathrm{I}_{\mathrm{tr}}-\mathrm{I}_{\mathrm{s}}\right) \leq \mathrm{I}_{\mathrm{tr}} \\
\mathrm{V}_{\mathrm{h}}^{\prime} \leq \mathrm{V}_{\mathrm{h}}
\end{gathered}
$$

in which $I_{s}=$ moment of inertia for the steel section, $I_{t r}=$ moment of inertia of the 
transformed composite section, $\mathrm{V}_{\mathrm{h}}^{\prime}=$ sum of the shear stud capacities between the point of maximum moment and the nearest point of zero moment, and $\mathrm{V}_{\mathrm{h}}=$ smaller of the tensile yield capacity of the net steel section or the crushing strength of the concrete slab.

For models using $\mathrm{I}_{\mathrm{lb}}$, the concrete deck is replaced by an equivalent steel area based on the ratio of the crushing strength of the concrete to the yield strength of the steel, $0.85 \mathrm{f}_{\mathrm{c}}^{\prime} / \mathrm{F}_{\mathrm{y}} \cdot \mathrm{I}_{\mathrm{lb}}$ is calculated using the provisions of Part 4 of the AISC Load and Resistance Factor Design Manual of Steel Construction (AISC 1986) and is given by:

$$
\mathrm{I}_{\mathrm{lb}}=\mathrm{I}_{\mathrm{s}}+\mathrm{A}_{\mathrm{s}}\left(\mathrm{Y}_{\mathrm{ENA}}-\frac{\mathrm{d}}{2}\right)^{2}+\frac{\Sigma_{\mathrm{Q}_{\mathrm{n}}}}{\mathrm{F}_{\mathrm{y}}}\left(\mathrm{d} \partial \mathrm{Y}_{2}-\mathrm{Y}_{\mathrm{ENA}}\right)^{2}
$$

in which $A_{s}=$ cross-sectional area of the steel section, $Y_{\mathrm{ENA}}=$ distance from the bottom of the beam to the elastic neutral axis, $d=$ depth of the beam, $\Sigma Q_{n}=$ the smaller of the tensile yield capacity of the gross steel section, the crushing capacity of the concrete slab, or the sum of the shear stud capacities between the point of maximum moment and the nearest point of zero moment, $F_{y}=$ yield stress of the steel, and $Y_{2}=$ distance from the concrete flange force to the beam top flange.

Moments of inertia in the region of the web opening. - The bending stiffness of the bottom tee is represented using the elastic moment of inertia, while the bending stiffness of the top tee is represented using three different modeling assumptions. In each of the three cases, both $\mathrm{I}_{\text {eff }}$ and $\mathrm{I}_{\mathrm{lb}}$ are considered.

For Model 1, it is assumed that the concrete above an opening will not contribute significantly to the bending stiffness of the top tee. For this model, the moment of inertia of the top tee is calculated considering the steel tee only.

For Model 2, the concrete above the opening is included in the bending stiffness of the top tee. For this model, the moment of inertia for the top tee is computed considering both the steel tee and the transformed area of concrete above the opening. Moments of inertia for the top tee, $\mathrm{I}_{\text {eff }}$ or $\mathrm{I}_{1}$, are calculated using the procedures discussed ahove.

For Model 3, two beam elements of equal length are used to represent the top tee. At the low moment end of the opening, the concrete is neglected and only the steel tee is considered in calculating the moment of inertia. At the high moment end, the bending 
stiffness of the top tee is calculated considering both the steel tee and the transformed area of the concrete deck. Again both $\mathrm{I}_{\mathrm{eff}}$ and $\mathrm{I}_{\mathrm{lb}}$ are considered. Of the three models, Model 3 should provide the most realistic results, since the concrete slab tends to crack in tension over the low moment end of the opening in cases where the opening region is subjected to a shear (Clawson and Darwin 1980, Donahey and Darwin 1986).

Effective area for carrying axial force. - For all three models, the effective area for carrying axial force within the top tee, $A_{t}$, is taken as the area of the steel tee plus the transformed area of the concrete deck. The centroid of the top tee is taken as the centroid of the transformed section. Therefore, the length of the rigid link, $l_{t}$, is taken as the distance from the centroid of the nonperforated section to the centroid of the transformed section for the top tee.

Effective area for carrying shear force. -- Only the webs of the steel sections are considered effective in carrying the shear. Away from the opening,

$$
\mathrm{A}_{\mathrm{y}}=\mathrm{dt}_{\mathrm{w}}
$$

in which $d$ is the depth of the steel section and $t_{w}$ is the thickness of the web. At an opening, the effective shear areas for the top and bottom tees are taken as:

$$
A_{y t}=s_{t} t_{w}
$$

$$
A_{y b}=s_{b} t_{w}
$$

in which $s_{\mathrm{t}}$ and $\mathrm{s}_{\mathrm{b}}$ are the depths of the top and bottom steel tees, respectively.

Material properties. -- Steel sections are modeled using $\mathrm{E}=29,000 \mathrm{ksi}$ and $\mathrm{G}=$ 11,150 ksi. The elastic modulus for concrete is taken as $E=57 \sqrt{f_{c}^{\prime}}$ ksi, with $f_{c}^{\prime}$ in psi.

\section{PARAMETRIC STUDY}

\section{General}

The analytical procedures described above are compared with actual test results to determine the accuracy of the method. The calculated deflections are compared with the 
deflections of twenty-five test beams. Models of entire beams, as well as models of web openings only, are used. Models of test beams include rigid links at the supports, as well as at the openings, and incorporate beam elements to represent unperforated sections of the beams (Fig. 4). The rigid links connect the bottom flange of the steel section to the centroid of the transformed section to properly model the test beams, which were all supported at the bottom flange. Models of the web opening. only include a fixed support at the low moment end (Fig. 5).

The deflection data used in the parametric study include 13 tests by Donahey and Darwin (1986), 6 tests by Clawson and Darwin (1980), 2 tests by Granade (1968), and 4 tests by Redwood and Wong (1982). The beams are designated, respectively, with numbers only, $\mathrm{c}, \mathrm{g}$, and $\mathrm{r}$. Two of the beams tested by Redwood and Wong had coverplates. Detailed dimensions for the coverplates were not published. A coverplate of the same thickness and width as the beam flanges is assumed in this study. Data on the two beams tested by Granade (1968) include maximum deflection, but not deflection across the opening.

The test beams were designed primarily to obtain information on the strength at web openings. The beams were relatively short, and opening locations were predominately in high shear regions. For this reason, the relative importance of shear deflections and the deflections through the opening will be greater than for beams in which flexural deformations play a greater role. To study the importance of shear deformation in total beam deflection, analyses that account for shear deformations throughout the span, $\mathrm{V}$, are compared with analyses that ignore shear deformations throughout the span, NV. Comparisons are made at loads equal to 30 and 60 percent of the ultimate applied load.

\section{Comparisons with Test Data}

Beam models. --The following comparisons are based on deflections under applied load; dead load deflections are not considered. Calculated and measured test deflections are presented in Appendix A, Tables A.1 through A.12, along with the ratios of calculated to measured deflection. The means, standard deviations, and coefficients of variation for the ratios are also given for each model. The models are compared to each other, and the best model is chosen for predicting the deflection at the point of maximum moment and the deflection across the opening. As will be shown in the following discussion, the best 
results for the deflection at the point of maximum moment are obtained using Model 2, while Model 3 performs best in predicting the deflection across the opening.

Deflections at the point of maximum moment. -- The mean ratio of calculated deflection to measured test deflection, along with the standard deviation and coefficient of variation for each model, are shown in Table 1.

Review of Table 1 shows that shear deformations are important. Ignoring shear deformations, NV, causes the models to be too stiff and thus unconservative (mean ratios of calculated to test deflections less than 1.0). From a practical point of view, it is better to have the calculated deflections somewhat above the actual to provide for adequate stiffness in the structure. Including shear deformation, $\mathrm{V}$, yields a more flexible model.

In most cases, the models which include shear deformations, $V$, provide a better agreement with the test results. At an applied load of 30 percent of ultimate, models including shear, $\mathrm{V}$, have mean ratios of calculated deflections to measured deflections of 1.13, 0.94, and 0.97 using $I_{\text {eff }}$ and 1.26, 1.08, and 1.11 using $I_{1 b}$ for Models 1, 2, and 3, respectively. Ignoring shear deformations, NV, the respective models have mean ratios of $0.97,0.76$, and 0.80 using $\mathrm{I}_{\text {eff }}$ and $1.10,0.9$, and 0.94 using $\mathrm{I}_{\mathrm{lb}}$. At an applied load of 60 percent of ultimate, $\mathrm{V}$ models have mean ratios of $1.01,0.84$, and 0.87 using $I_{\text {eff }}$ and 1.13 , 0.97 , and 1.00 using $\mathrm{I}_{\mathrm{lb}}$, while $\mathrm{NV}$ models have mean ratios of $0.86,0.68$, and 0.72 using $\mathrm{I}_{\text {eff }}$ and $0.98,0.81$, and 0.84 using $\mathrm{I}_{\mathrm{lb}}$.

The mean ratios of calculated to measured deflection given in Table 1 also show that models using $I_{1 b}$ are less stiff than those using $I_{\text {eff }}$ For example, at 30 percent of ultimate and including shear deformation, the mean ratios for Model 1, which does not include the contribution of the concrete over the opening, are 1.13 using $\mathrm{I}_{\text {eff }}$ versus 1.26 using $\mathrm{I}_{\mathrm{lb}}$. For Model 2, where the bending stiffness of the top tee includes the transformed area of the concrete, the mean ratios are 0.94 using $\mathrm{I}_{\text {eff }}$ and 1.08 using $\mathrm{I}_{\mathrm{lb}}$. For Model 3, where the top tee is modeled using the steel tee at the low moment end and the composite tee at the high moment end, the mean ratios are 0.97 using $\mathrm{I}_{\text {eff }}$ and 1.11 using $\mathrm{I}_{\mathrm{ib}}$. At an applied load of 60 percent of ultimate, Model 1 has a mean ratio of 1.01 using $\mathrm{I}_{\text {eff }}$ and 1.13 using $\mathrm{I}_{\mathrm{b}^{*}}$. Model 2 has mean ratios of 0.84 using $\mathrm{I}_{\mathrm{eff}}$ and 0.97 using $\mathrm{I}_{\mathrm{b}}$. Model 3 has mean ratios of 0.87 using $I_{\text {eff }}$ and 1.00 using $I_{\mathrm{lb}}$.

In summary, it can be seen that the models which use $I_{\mathrm{lb}}$ and include shear deformations, $\mathrm{V}$, provide the best overall agreement with the test data for total deflection. 
Of these models, Model 2 provides the best performance and least scatter in the data. Figs. 6 and 7 compare deflections calculated using Model $2\left(\mathrm{I}_{\mathrm{bb}}, \mathrm{V}\right)$ to the test deflections at the point of maximum moment. At 30 percent of the ultimate load, the model has a mean ratio of calculated to measured deflection of 1.08 , with a standard deviation of 0.18 and a coefficient of variation of 16.5 percent. At 60 percent of the ultimate load, the model has a mean ratio of 0.97 , with a standard deviation of 0.15 and a coefficient of variation of 15.1 percent. Overall, deflections at the point of maximum moment calculated using Model $2\left(\mathrm{I}_{\mathrm{lb}}, \mathrm{V}\right)$ are in close agreement with the measured deflections.

An important point to note is that there is a decrease in the mean ratio of calculated to test deflection as the load is increased from 30 to 60 percent of ultimate. All of the models exhibited this behavior. This is a reflection of the relatively early onset of yielding around the opening.

Deflections across the opening. -- For deflection across the opening, the agreement between calculated and test deflections is not as good as that obtained for deflection at the point of maximum moment. The comparisons are summarized in Table 2 and include the mean ratios of calculated to measured deflection, along with the standard deviations and coefficients of variation. All of the models exhibit a large amount of scatter when compared to the measured deflections, as reflected by the large coefficients of variation.

As stated previously, models that ignore shear deformation, NV, are stiffer than models that include shear deformation, $V$. Moreover, models that use $I_{\text {eff }}$ are stiffer than models that use $I_{1 b}$. In general, the models that use $I_{\mathrm{lb}}$ and include shear deformation provide the best agreement with the test data.

The calculations for deflection across the opening are sensitive to the assumptions made concerning composite behavior over the opening. Model 1, in which composite action over the opening is neglected, is generally too flexible and overly conservative. Model 2, however, which assumes composite action over the entire length of the opening, is too stiff and unconservative. At 30 percent of ultimate load and including shear deformations, the mean ratios of calculated to measured deflection for Model 1 are 1.59 . using $\mathrm{I}_{\text {eff }}$ and 1.64 using $\mathrm{I}_{\mathrm{lb}}$. For Model 2, the mean ratios are 0.74 and 0.83 using $\mathrm{I}_{\text {eff }}$ and $I_{\mathrm{b}}$, respectively. At 60 percent of ultimate, the mean ratios are 1.15 and 1.24 using Model 1 and 0.58 and 0.65 using Model 2.

Model 3 gives the best results for deflection across the opening. This model 
considers composite action over the opening only at the high moment end, while the moment of inertia for the top tee at the low moment end is calculated using the steel tee only. Deflections calculated using this model are still generally lower than the test deflections, but the scatter in the data is less than that for Model 1. At 30 percent of ultimate load, the model has a mean ratio of 1.0 , with a standard deviation of 0.44 and a coefficient of variation of 43.7 percent. At 60 percent of ultimate, the mean ratio is 0.77 , with a standard deviation of 0.35 and a coefficient of variation of 45.1 percent.

Opening models (simplified Model 3). -- For models of the opening only, the assumptions used to represent the top and bottom tees at the opening are the same as for Model 3. The top tee is modeled using two uniform beam elements. At the low moment end of the opening, only the steel tee is used to calculate the moment of inertia. At the high moment end, the transformed area of the concrete deck is included in the calculation of $\mathrm{I}_{\mathrm{lb}}$. The node at the center line of the opening is condensed out of the local stiffness matrix for the top tee. The bottom tee is represented by a single uniform beam element. The top and bottom tees are connected at the ends by rigid links.

The beam is fixed at the low moment end of the opening and free to deflect at the high moment end. The shear and the bending moment at the high moment end are applied to the web opening element. An initial rotation, $\theta$, is assumed at the low moment end (Fig. 5). This rotation is taken as the rotation at the position of the low moment end of the opening in the unperforated beam under full loading.

The measured and calculated deflections are compared for 23 tests in Table 3, along with the ratios of calculated to measured deflection, mean ratios, standard deviations, and coefficients of variation. In comparing the data for this model with the data previously given for Model 3, it can be seen that the two models are very similar. Considering only the region around the opening gives a model which is slightly more flexible than the full beam model. Comparing the deflection across the opening obtained with the simplified model to the deflection obtained with the full beam model the mean ratios are 1.03 versus 1.00 at 30 percent of ultimate and 0.79 versus 0.77 at 60 percent of ultimate. The data scatter is virtually identical for the two models. The calculated deflections for the simplified model are compared to the test deflections at 30 and 60 percent of ultimate load in Figs. 8 and 9, respectively. 


\section{Summary of Parametric Study}

In summary, the preferred model for predicting the total deflection is Model 2, while Model 3 performs best for predicting the deflections across the opening. In both cases, the preferred models use $\mathrm{I}_{\mathrm{lb}}$ and include shear deformations in the analysis. The following case studies are based on these two models.

\section{CASE STUDIES AND DESIGN APPLICATIONS}

The comparisons discussed above show that matrix analysis procedures provide close agreement with test results for total deflection and are reasonably accurate for predicting the deflection across the opening. However, most of the test beams had relatively short spans, and all of the beams were loaded with point loads. Since this is not typical of actual construction, limited studies were undertaken to investigate the effect of web openings on uniformly loaded beams of longer span.

The case studies treat the total deflection and the deflection across the opening separately. Model 2 is used to predict the total deflection, and the simplified version for Model 3 (only the region around the opening is investigated) is used to predict the deflection across the opening. Specific design recommendations will be made for each case.

The composite beams in the case study have a 4.5 in. ribbed deck ( 2 in. ribs) and are spaced at $9 \mathrm{ft}$. on center. Three steel sections are considered: 1) W $24 \times 55$ with a 39 ft. span and uniform load, $w=1.76 \mathrm{k} / \mathrm{ft} ; 2) \mathrm{W} 18 \times 35$ with a $30 \mathrm{ft}$. span and $w=1.73$ $\mathrm{k} / \mathrm{ft}$; and 3) $\mathrm{W} 14 \times 22$ with $21 \mathrm{ft}$. span and $\mathrm{w}=1.72 \mathrm{k} / \mathrm{ft}$. A total of 45 combinations of opening size and location are modeled for each span. Opening size is determined using an opening height to steel beam depth ratio $\left(h_{\alpha} / d\right)$ and an opening length to opening height ratio $\left(a_{0} / h_{0}\right)$. Three $h_{0} / d$ ratios $(0.3,0.5$, and 0.7$)$, three $a_{0} / h_{o}$ ratios $(1,2$, and 3$)$, and five locations for the opening center line with respect to the support $\left(L_{0}=1 / 16,1 / 8,1 / 4,3 / 8\right.$, and $1 / 2 L_{s}$ ) are considered for each beam. All beams were modeled with simple supports located at the centroid of the transformed section.

\section{Deflection at the point of maximum moment}

One of the purposes of the case study is to obtain factors which can be used to 
estimate the total deflection of a beam with an opening based on the deflection of the same beam without an opening.

Comparison of beams with and without web openings. -- The total deflection at the point of maximum moment, $\Delta_{\mathrm{m}}$, is calculated using Model 2 (a single uniform composite beam element over the opening, moments of inertia $=\mathrm{I}_{\mathrm{lb}}$, and shear deformations included throughout the span).

For comparison, the maximum deflection of a uniformly loaded beam without a web opening is calculated using classical beam theory:

$$
\begin{gathered}
\Delta_{\mathrm{b}}=\frac{5 \mathrm{wL}_{\mathrm{s}}^{4}}{384 \mathrm{EI}} \\
\Delta_{\mathrm{s}}=\frac{w L_{s}^{2}}{8 \mathrm{~A}_{\mathrm{y}} \mathrm{G}}
\end{gathered}
$$

in which $\Delta_{\mathrm{b}}=$ the maximum deflection considering bending only, and $\Delta_{\mathrm{s}}=$ the maximum deflection considering shear only. The calculated values for $\Delta_{\mathrm{m}}$ and the ratios $\Delta_{\mathrm{m}} / \Delta_{\mathrm{b}}$ and $\Delta_{m} /\left(\Delta_{b}+\Delta_{s}\right)$ are given Table 4 .

It can be seen from the data in Table 4 that the effect of the web opening can be significant. As the relative size of the opening increases, the ratio $\Delta_{\mathrm{m}} / \Delta_{\mathrm{b}}$ ranges between 1.038 and $1.171,1.047$ and 1.181 , and 1.069 and 1.222 for the $W 24 \times 55, W 18 \times 35$, and W $14 \times 22$ sections, respectively. The ratio $\Delta_{\mathrm{m}} /\left(\Delta_{\mathrm{b}}+\Delta_{\mathrm{s}}\right)$ ranges between 1.001 and 1.129 for the W $24 \times 55$ and $W 18 \times 35$ sections, and between 1.001 and 1.144 for the $W 14 \times 22$ section. Note that in most cases, the effects of shear deformation are more important than the effects of the web opening. For all web openings with $h_{\alpha} / d \leq 0.3$ or $a_{0} / h_{o} \leq 1$, independent of opening location, the web opening caused an increase in maximum deflection of less than 5 percent.

The opening location has somewhat less effect on total deflection than does the opening size. Fig. 10 compares the ratio, $\Delta_{\mathrm{m}} /\left(\Delta_{\mathrm{b}}+\Delta_{\mathrm{s}}\right)$, to the location of the opening center line, $L_{0}$, for the W $14 \times 22$ section. It can be seen that both th; opening size and the opening center line location affect the deflection at the point of maximum moment. As the opening depth, $h_{0}$, is increased from $0.3 d$ to $0.7 d$, and as the opening length, $a_{0}$, is increased from $1 h_{0}$ to $3 h_{0}$, the deflection at the point of maximum moment increases. For 
all size openings, the maximum deflection occurs when the opening center line and the span center line coincide. The W $24 \times 55$ and $\mathrm{W} 18 \times 35$ sections also give similar results. This suggests that for a given opening size, the maximum deflection with the opening located at the span center line can be used as a conservative estimate of the maximum deflection for any location of the opening.

Design recommendations. -- One option for design is to use Table 4, or a table like it, to conservatively estimate the effect of an opening on the maximum deflection of a beam. A somewhat more general, yet more conservative, approach is to estimate the maximum deflection by assuming that the opening is located at the span center line. The latter procedure will now be discussed.

For a simply supported beam under uniform load, the center portion of the span is subjected to high moment and low shear. The increase in total deflection caused by an opening at the span center line is due primarily to the increase in curvature caused by the lower gross moment of inertia at the opening. Therefore, only bending deflections must be considered to approximate the maximum increase in the total deflection due to the opening. These observations allow the use of a greatly simplified structural model, pictured in Fig. $-11$.

For the simplified model, the maximum deflection due to bending only, $\Delta_{\mathrm{m}, \mathrm{b}}$, can be calculated using the unit load method:

$$
\Delta_{m, b}=\int_{0}^{L_{s}} \frac{M(x) m(x)}{E I} d x
$$

For the nonperforated sections of beam, the moment of inertia, $I_{g}$, is taken as the lower bound moment of inertia for the gross transformed section. The moment of inertia for the beam in the region of the opening $I_{w o}$ is taken as the moment of inertia for the top and bottom tees about the centroid of the transformed section without an opening:

$$
I_{w o}=I_{t}+A_{t} I_{t}^{2}+I_{b}+A_{b} I_{b}^{2}
$$

The moment of inertia for the top tee, $I_{t}$, is also calculated using the lower bound moment of inertia. 
Substituting the appropriate moments of inertia into Eq. 11 and carrying out the integration gives $\Delta_{\mathrm{m}, \mathrm{b}}$. The ratio of the maximum deflection of a uniformly loaded beam with an opening to the maximum deflection of a beam without an opening, $\Delta_{m, b} / \Delta_{b}$, can be written as:

$$
\frac{\Delta_{\mathrm{m}, \mathrm{b}}}{\Delta_{\mathrm{b}}}=1+\frac{1}{5}\left(\frac{\mathrm{a}_{\mathrm{o}}}{\mathrm{L}_{\mathrm{s}}}\right)\left[\frac{\mathrm{I}_{\mathrm{g}}}{\mathrm{I}_{\mathrm{wo}}}-1\right]\left[3\left(\frac{\mathrm{a}_{\mathrm{o}}}{\mathrm{L}_{\mathrm{s}}}\right)^{3}-4\left(\frac{\mathrm{a}_{\mathrm{o}}}{\mathrm{L}_{\mathrm{s}}}\right)^{2}-6\left(\frac{\mathrm{a}_{\mathrm{o}}}{\mathrm{L}_{\mathrm{s}}}\right)+12\right]
$$

or

$$
\frac{\Delta_{m, b}}{\Delta_{b}}=f\left(\frac{I_{g}}{I_{w o}}, \frac{a_{o}}{L_{s}}\right)
$$

Eq. 13 can be used to develop a design aid based on the ratios $I_{g} / I_{w o}^{\circ}$ and $a_{0} / L_{s}$, as shown in Fig. 12. Each curve in Fig. 12 represents a constant value of $\Delta_{\mathrm{m}, \mathrm{b}} / \Delta_{\mathrm{b}}$. Given $\Delta_{m, b} / \Delta_{b}$ and the deflection for the unperforated beam, the total bending deflection for the perforated beam can be readily calculated.

Since Fig. 12 considers deflection due to bending only, the estimate for deflection can be improved by including shear deformation to the analysis. Then the maximum deflection for a beam with a web opening can be written as:

$$
\Delta_{\mathrm{m}}=\Delta_{\mathrm{m}, \mathrm{b}}+\Delta_{\mathrm{s}}
$$

\section{Deflections across the opening}

For cases where the web opening center line does not coincide with the span center line, the deflection across the opening should also be considered when checking the serviceability of a beam. In this study, the deflection is divided into three parts: 1) the deflection due to a rotation $\theta, 2$ ) the deflection due to a shear load $\mathrm{P}$, and 3) the deflection due to a moment M. Equations will be derived for each case.

Deflections across the opening are calculated using the simplified version of Model 3, where, as described earlier, only the region around the opening is investigated. As 
shown in Fig. 5, the low moment end of the opening is considered to be fixed and given an initial rotation $\theta$ equal to that in the same beam without an opening, while the high moment end is free to rotate and deflect. The shear force, $\mathrm{P}$, and the bending moment, $\mathrm{M}$, at the high moment end are applied as shown.

The three beams described at the beginning of the Case Studies section are again considered here. The results for this portion of the case studies are shown in Appendix B, Tables B1 through B6. The deflections in Tables B1 - B3 include the effects of shear deformation, while the deflections in Tables B4 - B6 include the effects of bending only. Openings located at $L_{o} / L_{s}=1 / 2$ are not considered because deflection across the opening is zero for openings located at the span center line of a symmetrically loaded beam.

In general, the absolute magnitude of the deflection increases as the length of the opening increases and as the opening center line is moved closer to the support. The total deflection across the opening, $\Delta_{\mathrm{y}}$ (subscript $\mathrm{y}$ represents a vertical displacement), given in Tables B1 - B3 give a good indication of the magnitude of deflections that will occur under service loads in composite members built using shored construction. Many of the cases illustrated result in very small deflections which will make moot much of the discussion that follows. However, Tables B1 - B3 also include deflections as large as 0.78 inches over a 50 inch opening length, which may be objectionable. The discussion that follows provides additional guidance if a detailed deflection check is warranted.

Deflection across the opening due to the rotation $\theta$. .- The deflection due to the rotation $\theta, \Delta_{\mathrm{y}}^{(\theta)}$, is a significant percentage of $\Delta_{\mathrm{y}}$. As shown in Tables B1 - B3 (shear deformations are included in the total deflection) the minimum percentage of $\Delta_{\mathrm{y}}$ due to $\theta$ is 32.9 percent $\left(\Delta_{y}^{(\theta)} / \Delta_{y}=0.329\right)$, for the W $14 \times 22$ section with $h_{o} / d=0.7$ and $a_{o} / h_{o}=3$. The maximum percentage is 123.6 percent $\left(\Delta_{\mathrm{y}}^{(\theta)} / \Delta_{\mathrm{y}}=1.236\right)$, for the $\mathrm{W} 24 \times 55$ section with $h_{\mathrm{o}} / \mathrm{d}=0.5$ and $\mathrm{a}_{\mathrm{o}} / \mathrm{h}_{\mathrm{o}}=3$.

The rotation, $\theta$, is taken as the rotation in the beam as if the opening were not present. For a simply supported beam with a uniform load, the rotation at a point $\mathrm{x}$ is given by:

$$
\theta=\frac{w}{24 E I}\left(-L_{s}^{3}+6 L_{s} x^{2}-4 x^{3}\right)
$$


in which $w=$ the uniform load, and $x=$ the distance from the low moment end of the opening to the support $\left(L_{o}-a_{d} / 2\right)$.

The deflection across the opening due to $\theta$ can then be written as:

$$
\Delta_{\mathrm{y}}^{(\theta)}=a_{\mathrm{o}} \theta
$$

In the simplified version of Model 3, the high moment end is free to deflect and rotate. The rotation about the low moment end, $\theta$, is a rigid body motion and there is no shear deformation. In Tables $\mathrm{B} 1$ and $\mathrm{B} 4, \mathrm{~B} 2$ and $\mathrm{B} 5$, and $\mathrm{B} 3$ and $\mathrm{B} 6$, the values of $\Delta_{\mathrm{y}}^{(\theta)}$ are identical whether or not shear deformation is considered and do not represent an effect of the opening.

Deflections across the opening due to shear force $P$. -- Deflections due to a constant shear force $P$ (Fig.5) consist of two components: 1) the deflection due to secondary bending, $\Delta_{y, b}^{(P)}$, and 2) the deflection due to shear deformation $\Delta_{y, s^{*}}^{(P)}$. In general, for a large opening, the deflection will primarily be due to secondary bending. For smaller openings, shear deformations dominate. Separate equations are derived for the two cases.

The deflection due to secondary bending can be calculated using the stiffness method of matrix analysis. For the case of the web opening subjected to shear, the element stiffness equations can be written as:

$$
\left[\begin{array}{ccc}
\mathrm{K}_{11} & 0 & \mathrm{~K}_{13} \\
0 & \mathrm{~K}_{22} & \mathrm{~K}_{23} \\
\mathrm{~K}_{31} & \mathrm{~K}_{32} & \mathrm{~K}_{33}
\end{array}\right]\left\{\begin{array}{c}
\Delta_{\mathrm{x}, \mathrm{b}}^{(\mathrm{P})} \\
\Delta_{\mathrm{y}, \mathrm{b}}^{(\mathrm{P})} \\
\Delta_{\mathrm{s}, \mathrm{b}}^{(\mathrm{P})}
\end{array}\right\}=\left\{\begin{array}{l}
0 \\
\mathrm{P} \\
0
\end{array}\right\}
$$

in which the subscript $b$ indicates that only bending deformations are included, subscripts $\mathrm{x}, \mathrm{y}$, and $\mathrm{r}$ refer to the positive global directions, as shown in Fig. 5 , and $\mathrm{P}=$ the shear force applied at the high moment end.

Considering bending only, terms in the structure stiffness matrix can be written as: 


$$
\begin{aligned}
& K_{11}=\frac{E}{a_{o}}\left(A_{b}-A_{t}\right) \\
& K_{13}=K_{31}=\frac{E}{a_{o}}\left(I_{b} A_{b}-I_{t} A_{1}\right) \\
& K_{22}=\frac{96 E}{a_{0}^{3}}\left[I_{t 2} \cdot \frac{I_{t 2}^{2}\left\{7\left(I_{t 1}+I_{t 2}\right)-6\left(I_{t 2}-I_{t 1}\right)\right\}}{I_{t 1}^{2}+\left(14 I_{t 1} I_{t 2}+I_{t 2}^{2}\right)}\right]+\frac{12 E}{a_{o}^{3}} I_{b} \\
& K_{23}=K_{32}=\frac{-24 E}{a_{o}^{2}}\left[I_{t 2}-\frac{I_{t 2}^{2}\left\{6\left(I_{t 1}+I_{t 2}\right)-5\left(I_{t 2}-I_{t 1}\right)\right\}}{I_{t 1}^{2}+\left(14 I_{t 1} I_{t 2}+I_{t 2}^{2}\right)}\right]+\frac{-6 E}{a_{o}^{2}} I_{b} \\
& K_{33}=\frac{8 E}{a_{o}}\left[I_{t 2}-\frac{I_{t 2}^{2}\left\{4\left(I_{t 1}+I_{t 2}\right)-3\left(I_{t 2}-I_{t 1}\right)\right\}}{I_{t 1}^{2}+\left(14 I_{t 1} I_{t 2}+I_{t 2}^{2}\right)}\right]+\frac{4 E}{a_{o}} I_{b}+\frac{E}{a_{o}}\left(I_{t}^{2} A_{t}+I_{b}^{2} A_{b}\right)
\end{aligned}
$$

in which $I_{t 1}=$ moment of inertia for the top tee at the low moment end of the opening, $I_{t 2}$ $=$ moment of inertia for the top tee at the high moment end of the opening, and $\mathrm{I}_{\mathrm{b}}=$ the moment of inertia for the bottom tee.

Since $\mathrm{I}_{\mathrm{t} 1}^{2}$ is small in comparison to $14 \mathrm{I}_{\mathrm{t} 1} \mathrm{I}_{\mathrm{t} 2}+\mathrm{I}_{\mathrm{t} 2}^{2}$, the individual terms, $\mathrm{K}_{22}, \mathrm{~K}_{23}$, and $\mathrm{K}_{33}$, in Eq. 18 can be approximated by:

$$
\begin{aligned}
& \mathrm{K}_{22} \cong \frac{12 E}{a_{o}^{3}}\left(8 I_{e q}+I_{b}\right) \\
& K_{23} \cong \frac{-6 E}{a_{o}^{2}}\left(12 I_{e q}+I_{b}\right) \\
& K_{33} \cong \frac{4 E}{a_{o}}\left(14 I_{e q}+I_{b}\right)+\frac{E}{a_{o}}\left(l_{t}^{2} A_{t}+l_{b}^{2} A_{b}\right)
\end{aligned}
$$

in which $I_{e q}=\frac{I_{t 1} I_{t 2}}{14 I_{t 1}+I_{t 2}}$

Solving Eq. 17 for the vertical deflection across the opening due to the applied shear load, P, gives: 


$$
\Delta_{y, b}^{(P)}=\frac{-K_{13}^{2}+K_{11} K_{33}}{K_{13}^{2} K_{22}+K_{11} K_{22} K_{33}-K_{11} K_{23}^{2}} P
$$

Since $K_{13}^{2}$ is small compared to $K_{11} K_{33}$, and $K_{13}^{2} K_{22}$ is small compared to $\left(\mathrm{K}_{11} \mathrm{~K}_{22} \mathrm{~K}_{33}-\mathrm{K}_{11} \mathrm{~K}_{23}^{2}\right)$, Eq. 20 can be approximated by :

$$
\Delta_{y, b}^{(\mathrm{P})}=\frac{\mathrm{K}_{33}}{\mathrm{~K}_{22} \mathrm{~K}_{33}-\mathrm{K}_{23}^{2}} \mathrm{P}
$$

Substituting Eq. 19 into Eq. 21 gives:

$$
\Delta_{y, b}^{(P)}=\frac{a_{o}^{3}}{12 E}\left[\frac{4\left(14 I_{e q}+I_{b}\right)}{\left(8 I_{e q}+I_{b}\right)\left(I_{t}^{2} A_{t}+l_{b}^{2} A_{b}\right)}+\frac{1}{\left(8 I_{e q}+I_{b}\right)}\right] P
$$

Eq. 22 can be simplified further by considering the upper and lower bounds on the ratio between the moments of inertia of the top and bottom tees. For openings with very stiff slabs, the value of $\mathrm{I}_{\mathrm{b}}$ will be small in comparison to $8 \mathrm{I}_{\mathrm{eq}}$. In this case, the ratio $\left(14 \mathrm{I}_{\text {eq }}\right.$ $\left.+\mathrm{I}_{\mathrm{b}}\right) /\left(8 \mathrm{I}_{\mathrm{eq}}+\mathrm{I}_{\mathrm{b}}\right)$ will approach an upper bound of 1.75 . Conversely, as the stiffness of the slab becomes negligible, taking $8 \mathrm{I}_{\text {eq }}=\mathrm{I}_{\mathrm{b}}$, the ratio $\left(14 \mathrm{I}_{\mathrm{eq}}+\mathrm{I}_{\mathrm{b}}\right) /\left(8 \mathrm{I}_{\mathrm{eq}}+\mathrm{I}_{\mathrm{b}}\right)$ will have an effective lower bound of 1.375 . If we select the median value, 1.5625, and substitute it into Eq. 22, this gives:

$$
\Delta_{y, b}^{(P)}=\frac{a_{o}^{3}}{12 E}\left[\frac{6.25}{l_{t}^{2} A_{t}+l_{b}^{2} A_{b}}+\frac{1}{8 I_{e q}+I_{b}}\right] P
$$

The values of $\Delta_{y, b}^{(\mathrm{P})}$ are calculated and compared using Eq. 23 and the matrix 
solution, Eq. 17. The results are given in Table 5. Examination of Table 5 reveals that Eq. 23 overestimates the deflection through the opening, but in general is in close agreement with the matrix solution (Eqs. 17 and 20). Deflections calculated using Eq. 23 approach the matrix solution as the ratio $h_{o} / d$ increases. For openings with $h_{\mathrm{o}} / d=0.3$, Eq. 23 overestimates the deflection by 19.3 percent, 14.7 percent, and 11 percent for the $\mathrm{W}$ $24 \times 55$, W $18 \times 35$, and $W 14 \times 22$ sections, respectively. For $h_{o} / d=0.7$, Eq. 23 overestimates the matrix solution by 4.3 percent, 2.3 percent, and 1.35 percent, respectively.

Eq. 23 is in close agreement with the matrix solution for large openings, and conservative for small openings. Although Eq. 23 is conservative for small openings, the total deflection across the opening is not severely affected. This is because the deflections due to secondary bending, $\Delta_{\mathrm{y}, \mathrm{b}}^{(\mathrm{P})}$, become significant only as the opening size increases. For small openings, the effects of secondary bending are negligible. Taking the $\mathrm{W} 24 \times 55$ section with $h_{o} / d=0.3$ and $a_{o} / h_{o}=1$ as an example, the deflection $\Delta_{y, b}^{(P)}$ is only 0.56 percent of $\Delta_{y}$. However, for the same beam with $h_{d} / d=0.7$ and $a_{o} / h_{o}=3, \Delta_{y, b}^{(P)}$ is 60.4 percent of $\Delta_{\mathrm{y}}$. Similar results are obtained for the W $18 \times 35$ and $\mathrm{W} 14 \times 22$ sections.

For the case of a web opening subjected to a shear load $\mathrm{P}$, the deflection due to the effects of shear deformation, $\Delta_{y, s}^{(P)}$, must also be considered.

The relative importance of shear deformation in the analysis increases as the length of the opening decreases. This is demonstrated in Table 6 , where the values $\Delta_{\mathrm{y}}^{(\mathrm{P})}$ and $\Delta_{\mathrm{y}, \mathrm{b}}^{(\mathrm{P})}$ are compared. The values in Table 6 are calculated using the simplified version of Model 3 (Fig. 5). For openings with $h_{0} / d=0.3$ and $a_{o} / h_{o}=1.0$, the ratio $\Delta_{y}^{(\mathrm{P})} / \Delta_{\mathrm{y}, \mathrm{b}}^{(\mathrm{P})}$ is 12.49 , 15.10, and 17.62 for the $\mathrm{W} 24 \times 55, \mathrm{~W} 18 \times 35$, and $\mathrm{W} 14 \times 22$ sections, respectively. For openings with $h_{o} / d=0.7$ and $a_{o} / h_{0}=3.0$, the ratios decrease to $1.135,1.172$, and 1.197.

As for $\Delta_{y, b}^{(\mathrm{P})}$, a simplified expression for $\Delta_{\mathrm{y}, \mathrm{s}}^{(\mathrm{P})}$ can be derived. Defining the stiffnesses for the top and bottom tee (including both bending and shear) as $K_{e q}$ and $K_{b}$ and again noting that $\mathrm{I}_{\mathrm{t} 1}^{2} \ll\left(14 \mathrm{I}_{\mathrm{t} 1} \mathrm{I}_{\mathrm{t} 2}+\mathrm{I}_{\mathrm{t} 2}^{2}\right)$ :

$$
K_{\mathrm{t}}=\frac{E \beta_{\mathrm{eq}}}{\mathrm{a}_{\mathrm{o}}} \quad \text { and } \quad \mathrm{K}_{\mathrm{b}}=\frac{E \beta_{\mathrm{b}}}{\mathrm{a}_{\mathrm{o}}}
$$


in which

$$
\begin{array}{ll}
\beta_{\text {eq }}=\frac{8 I_{\text {eq }}}{\left[\left(a_{0}^{2} / 12\right)+\eta_{\text {eq }}\right]}, & \eta_{\text {eq }}=\frac{8 E I_{\text {eq }}}{A_{y t} G} \\
\beta_{b}=\frac{I_{b}}{\left[\left(a_{0}^{2} / 12\right)+\eta_{b}\right]}, & \eta_{b}=\frac{E_{b}}{A_{y b} G}
\end{array}
$$

then the fraction of the shear load taken by the top tee $\lambda$ can be approximated as:

$$
\lambda=\frac{\beta_{\mathrm{eq}}}{\beta_{\mathrm{eq}}+\beta_{\mathrm{b}}}
$$

Therefore, the shear force applied to the end of the top tee can be taken as $\lambda \mathrm{P}$, and the shear deflection across the opening can be approximated by :

$$
\Delta_{y, s}^{(P)}=\frac{L}{A_{y t} G} \lambda P
$$

The deflections due to shear deformation calculated using Eq. 26 are compared with the matrix analysis solution $\left(\Delta_{y, s}^{(\mathrm{P})}=\Delta_{y}^{(\mathrm{P})}-\Delta_{y, b}^{(\mathrm{P})}\right)$ in Table 7. Eq. 26 overestimates the deflection, but the values are in close agreement when the size of the opening is small. For $h_{0} / d=0.3$ and $a_{0} / h_{o}=1.0$, Eq. $26^{\circ}$ overestimates $\Delta_{y, s}^{(P)}$ by 1.5 percent for the $W 24 \times 55$ section and 1.6 percent for the $\mathrm{W} 18 \times 35$ and $\mathrm{W} 14 \times 22$ sections.

In summary, the deflection due to shear can be a significant portion of the total deflection across the web opening. As discussed previously, the deflection due to $\mathrm{P}$ consists of two parts: $\Delta_{y}^{(\mathrm{P})}=\Delta_{y, b}^{(\mathrm{P})}+\Delta_{y, s^{*}}^{(\mathrm{P})}$. For large openings, it is more important to include the deflections due to secondary bending. Conversely, for small openings the effects of shear deformations become more significant. For design purposes, Eqs. 23 and 26 can be combined for estimating the total deflection across the opening due to shear. The results are in close agreement with the matrix analysis s lution.

Deflections across the opening due to moment $M$. -- For the case of the web opening subjected to a moment $\mathrm{M}$, the element stiffness equations can be assembled in matrix form as: 


$$
\left[\begin{array}{ccc}
\mathrm{K}_{11} & 0 & \mathrm{~K}_{13} \\
0 & \mathrm{~K}_{22} & \mathrm{~K}_{23} \\
\mathrm{~K}_{31} & \mathrm{~K}_{32} & \mathrm{~K}_{33}
\end{array}\right]\left\{\begin{array}{c}
\Delta_{\mathrm{x}, \mathrm{b}}^{(\mathrm{M})} \\
\Delta_{\mathrm{y}, \mathrm{b}}^{(\mathrm{M})} \\
\Delta_{\mathrm{t}, \mathrm{b}}^{(\mathrm{M})}
\end{array}\right\}=\left\{\begin{array}{c}
0 \\
0 \\
\mathrm{M}
\end{array}\right\}
$$

in which the subscript $\mathrm{b}$ indicates that only bending deformations are included, subscripts $\mathrm{x}, \mathrm{y}$, and $\mathrm{r}$ refer to the positive global directions, as shown in Fig. 7 , and $\mathrm{M}=$ the applied moment at the high moment end of the opening.

Considering bending and axial load terms only, the individual terms in the structure stiffness matrix are identical to those given in Eq. 18.

The element stiffness equations can be solved for the deflection across the opening due to $M$. The deflection, $\Delta_{y, b}^{(M)}$, is given by:

$$
\Delta_{y, b}^{(M)}=\frac{K_{11} K_{23}}{K_{13}^{2} K_{22}+K_{11} K_{22} K_{33}-K_{11} K_{23}^{2}} M
$$

Since $\mathrm{K}_{13}^{2} \mathrm{~K}_{22}$ is small compared to $\mathrm{K}_{11} \mathrm{~K}_{23}^{2}-\mathrm{K}_{11} \mathrm{~K}_{22} \mathrm{~K}_{33}$, Eq. 28 can be approximated by:

$$
\Delta_{y, b}^{(M)}=\frac{K_{23}}{K_{23}^{2}-K_{22} K_{33}} M
$$

Substituting for the individual stiffness terms in Eq. 29 yields:

$$
\Delta_{y, b}^{(M)}=\frac{a_{o}^{2}}{2 E}\left[\frac{\left(12 I_{e q}+I_{b}\right)}{\left(8 I_{e q}+I_{b}\right)\left(l_{t}^{2} A_{t}+1_{b}^{2} A_{b}\right)}\right] M
$$

Eq. 30 can be further reduced by considering that the ratio of $\left(12 \mathrm{I}_{\mathrm{eq}}+\mathrm{I}_{\mathrm{b}}\right) /\left(8 \mathrm{I}_{\text {eq }}+\mathrm{I}_{\mathrm{b}}\right)$ will have an upper bound of 1.5 and an effective lower bound of 1.25. Taking the median 
value, 1.375 , and substituting it into Eq. $30, \Delta_{y, b}^{(\mathrm{M})}$ can be expressed as:

$$
\Delta_{y, b}^{(M)}=\frac{a_{o}^{2}}{2 E}\left[\frac{1.375}{l_{t}^{2} A_{t}+l_{b}^{2} A_{b}}\right] M
$$

Deflections across an opening due to $M$ are calculated using the matrix equations (Eq. 28) and compared to the values obtained using Eq. 31. The results are given in Table 8. From the table, it can be seen that Eq. 31 overestimates the deflection for small openings and underestimates the deflection for large openings. For openings with an $h / d$ ratio of 0.3 , Eq. 31 overestimates the matrix solution by 16.6 percent, 11.6 percent, and 7.7 percent for the W $24 \times 55, \mathrm{~W} 18 \times 35$, and $\mathrm{W} 14 \times 22$ sections, respectively. For large openings with $h_{o} / d=0.7$, Eq. 31 underestimates the matrix solution by 3.3 percent, 4.9 percent, and 5.9 percent, respectively.

In most cases, the deflection across the opening due to $M$ adds little to $\Delta_{y}$. However, this component of the deflection does increase as the size of the opening increases and as the opening is located progressively closer to the span center line. The importance of including $\Delta_{\mathrm{y}, \mathrm{b}}^{(\mathrm{M})}$ in the analysis therefore increases as the relative size of the opening increases. This can be seen in Tables B4 - B6. For the W $24 \times 55$ with $h_{o} / d=0.3$ and $\mathrm{a}_{\mathrm{o}} / \mathrm{h}_{\mathrm{o}}=1, \Delta_{\mathrm{y}, \mathrm{b}}^{(\mathrm{M})}$ only accounts for 0.8 percent through 8.2 percent of $\Delta_{\mathrm{y}, \mathrm{b}}$ as the location of the opening ranges from $1 / 16 L_{s}$ to $3 / 8 L_{s}$. For the same beam with $h_{o} / d=0.7$ and $a_{0} / h_{o}=3, \Delta_{y, b}^{(M)}$ accounts for 5.2 percent through 57.4 percent of $\Delta_{y, b}$. Therefore, for small openings, overestimating the deflection $\Delta_{y, b}^{(\mathrm{M})}$ will not significantly affect the total deflection across the opening, $\Delta_{y, b}$.

Shear deformations also affect the values of deflection across an opening subjected to a bending moment. This is because the top and bottom tees in Model 3 tend to separate at the high moment end when subjected to a bending moment. Enforcing compatibility at the high moment end causes shears to be developed in the tees. These shears are the cause of the difference between $\Delta_{\mathrm{y}}^{(\mathrm{M})}$ and $\Delta_{\mathrm{y}, \mathrm{b}}^{(\mathrm{M})}$.

Table 9 compares the deflections across an opening subjected to a moment, both including shear deformation, $\Delta_{\mathrm{y}}^{(\mathrm{M})}$, and excluding shear deformations, $\Delta_{\mathrm{y}}^{(\mathrm{M})}$. The deflections $\Delta_{y}^{(M)}$ and $\Delta_{y}^{(M)}$ were calculated using the exact matrix solution for the model. Even for 
small openings, $h_{\alpha} / d=0.3$ and $a_{0} / h_{o}=1.0$, the maximum difference between $\Delta_{y}^{(M)}$ and $\Delta_{\mathrm{y}, \mathrm{b}}^{(\mathrm{M})}$, is only 4.6 percent, 6.2 percent, and 7.7 percent for the $\mathrm{W} 24 \times 55, \mathrm{~W} 18 \times 35$, and $\mathrm{W}$ $14 \times 22$ sections, respectively. For large openings with $h_{0} / d=0.7$ and $a_{0} / h_{0}=3.0$, the deflections $\Delta_{\mathrm{y}}^{(\mathrm{M})}$ and $\Delta_{\mathrm{y}, \mathrm{b}}^{(\mathrm{M})}$ are within 1 percent of each other. In all cases, for an opening subjected to a bending moment, the effect of shear deformation is small and in the current application their contribution is neglected.

Total deflection across the opening. -- Based on the previous discussion, the total deflection across an opening, $\Delta_{\mathrm{y}}$, can be expressed as the summation of: 1) the deflection due to a rigid body rotation, $\theta$, at the low moment end of the opening, $\Delta_{y}^{(\theta)}, 2$ ) the deflection due to an applied shear force, $\mathrm{P}$, at the high moment end of the opening, $\Delta_{\mathrm{y}}^{(\mathrm{P})}=$ $\Delta_{y, b}^{(\mathrm{P})}+\Delta_{\mathrm{y}, \mathrm{s}}^{(\mathrm{P})}$, and 3) the deflection due an applied bending moment, $\mathrm{M}$, at the high moment end of the opening, $\Delta_{\mathrm{y}}^{(\mathrm{M})}$. For design purposes, the total deflection across the opening can be calculated by combining Eqs. 16, 23, 26, and 31:

$$
\Delta_{\mathrm{y}}=\Delta_{\mathrm{y}}^{(\theta)}+\Delta_{\mathrm{y}, \mathrm{b}}^{(\mathrm{P})}+\Delta_{\mathrm{y}, \mathrm{s}}^{(\mathrm{P})}+\Delta_{\mathrm{y}, \mathrm{b}}^{(\mathrm{M})}
$$

Since Eq. 16 represents the deflection across the opening due to rotation of the unperforated beam, only the last three terms in Eq. 32 represent the real effects of the opening on local deflection.

Values for the total deflection calculated using Eq. 32 are compared to the solution of the matrix equations in Table 10. It can be seen that Eq. 32 is in close agreement with matrix solution. The ratio of the solution using Eq. 32 to the matrix solution ranges from a minimum of 0.962 to a maximum of 1.048 .

In Table 11, the calculated deflections using Eq. 32 are compared to the measured deflections across the openings for the 23 test beams. At 30 percent of ultimate, the calculated to measured ratios have a mean of 1.075 , with a standard deviation of 0.483 , and a coefficient of variation of 45.0 percent. At 60 percent of ultimate load the mean ratio decreases to 0.832 , with a standard deviation of 0.382 , and a coefficient of variation of 45.9 percent. These results show that Eq. 32 provides accuracy that is equivalent to th: matrix solutions. Depending on the practice within a design office, the matrix solutions presented in this report may prove to be competitive or even preferable to Eq. 32 . 


\section{SUMMARY AND CONCLUSIONS}

A web opening often has little effect on the deflections of a composite beam. However, there are important cases where the effect can be significant. Application of the stiffness method of matrix analysis provides a reasonable estimate of total deflection and deflection across the opening when compared with test data. The best match with experimental results is obtained by using the lower bound moment of inertia and including shear deformations in the analysis. For total deflection, the top tee is best modeled by including composite action over the full length of the tee, while deflection across the opening is best modeled by including composite action only over the high moment end of the opening.

Generally, the effects of the web opening and shear deflections over the span will be of the same order. Ignoring both the web opening and shear deformation can lead to significant error. For small openings, it is more important to consider shear deflections than the effects of a web opening. A conservative estimate of the effects of an opening can be obtained by analyzing a beam with the opening located at the span center line. Fig. 12 can be used to obtain the ratio of the total bending deflection of the perforated beam to the maximum bending deflection of the unperforated beam, $\Delta_{\mathrm{m}, \mathrm{b}} / \Delta_{\mathrm{b}}$, for a given opening size. Shear deformations throughout the span must be added to get the best estimate.

A simplified matrix model for the deflections across the opening has been developed which considers only the region around the opening. Modified equations for the total deflection across the opening are derived from the matrix model and evaluated. The results show that for large openings, the effects of shear deformation are negligible. Conversely, for small openings, bending deformations are negligible.

\section{ACKNOWLEDGEMENTS}

This report is based on research performed by Manuel A. Benitez in partial fulfillment of the requirements for the MSCE degree from the University of Kansas. Support for this project was provided by the University of Kansas Department of Civil Engineering, and the Structural Engineering and Materials Laboratory of the Center for Research, Inc. 


\section{REFERENCES}

AISC. (1989). Manual of Steel Construction, 9th ed. American Institute of Steel Construction. Inc., Chicago, IL.

AISC. (1986). Load and Resistance Factor Design Manual of Steel Construction, 1st ed. American Institute of Steel Construction. Inc., Chicago, IL

Clawson, W. C., and Darwin, D. (1980). "Composite Beams With Web Openings." SM Report No. 4, University of Kansas Center for Research, Inc., Lawrence, KS, $209 \mathrm{pp}$.

Cook, R. D. (1989). Concepts and Applications of Finite Element Analysis. 3rd. ed. John Wiley and Sons, New York, NY, 630 pp.

Donahey, R. C., and Darwin, D. (1986). "Performance and Design of Composite Beams with Web Openings." SM Report No. 18, University of Kansas Center for Research, Inc., Lawrence, KS, 267 pp.

Donahey, R. C. (1987). "Deflections of Composite Beams With Web Openings" Building Structures, Proceedings, ASCE Structures Congress, D. R. Sherman, Ed., Orlando, Florida, Aug. 1987, pp. 404-417.

Dougherty, B. K。 (1980). "Elastic Deformation of Beams With Web Openings." Journal of the Structural Division, ASCE, Vol. 106, No. ST1, pp. 301-312

Granade, C. J. (1968). "An Investigation of Composite Beams Having Large Rectangular Openings in Their Webs." M.S. thesis, University of Alabama, University, Al.

Lopez, L. A., Dodds, R. H., Jr., Rehak, D. R., and Schmidt, R. J. (1989). PoloFinite: A Structural Mechanics System for Linear and Nonlinear Analysis. A technical report by the University of Illinois at Urbana-Champaign.

McCormick, M. M. (1972). "Open Web Beams--Behavior, Analysis and Design." BHP Melbourne Research Laboratories Report MRL 17/18. Melbourne Research Laboratories, The Broken Hill Proprietary Co. Ltd., Clayton, Vic., Australia.

Redwood, R. G., and Wong, P. K. (1982). "Web Holes in Composite Beams With Steel Deck." Proceedings, 8th Canadian Struc. Engrg. Conf., Canadian Steel Construction Council, Willowdale, Ont., Canada.

"Suggested Design Guides for Beams With Web Holes." (1971). Journal of the Structural Division, ASCE, Vol. 97, No. ST11, pp. 2702-2728. 
Table 1. Summary of Models

(deflection at point of maximum moment)

30 percent of ultimate load:

\begin{tabular}{|c|c|c|c|c|c|c|c|c|c|c|c|c|}
\hline & \multicolumn{4}{|c|}{ Model 1} & \multicolumn{4}{|c|}{ Model 2} & \multicolumn{4}{|c|}{ Model 3} \\
\hline & \multicolumn{2}{|c|}{$I_{\text {off }}$} & \multicolumn{2}{|c|}{$I_{1 b}$} & \multicolumn{2}{|c|}{$\mathrm{I}_{\text {alf }}$} & \multicolumn{2}{|c|}{$I_{1 b}$} & \multicolumn{2}{|c|}{$I_{\text {eff }}$} & \multicolumn{2}{|c|}{$\mathrm{I}_{1 \mathrm{~b}}$} \\
\hline & $\mathrm{V}$ & NV & V & NV & $\mathrm{V}$ & NV & V & NV & V & NV & V & NV \\
\hline Mean & $\overline{1.13}$ & $\overline{0.97}$ & $\overrightarrow{1.26}$ & 1.10 & $\overline{0.94}$ & $\overline{0.76}$ & $\overline{1.08}$ & $\overline{0.90}$ & 0.97 & $\overline{0.80}$ & $\overline{1.11}$ & $\overline{0.94}$ \\
\hline Std. Dev. & 0.30 & 0.27 & 0.31 & 0.29 & 0.15 & 0.15 & 0.18 & 0.18 & 0.16 & 0.16 & 0.19 & 0.18 \\
\hline Coef. of Var. & 26.37 & 28.09 & 24.53 & 25.95 & 15.98 & 20.37 & 16.53 & 19.84 & 16.90 & 19.49 & 17.22 & 19.01 \\
\hline
\end{tabular}

60 percent of ultimate load:

\begin{tabular}{|c|c|c|c|c|c|c|c|c|c|c|c|c|}
\hline & \multicolumn{4}{|c|}{ Model 1} & \multicolumn{4}{|c|}{ Model 2} & \multicolumn{4}{|c|}{ Model 3} \\
\hline & \multicolumn{2}{|c|}{$I_{\text {eff }}$} & \multicolumn{2}{|c|}{$I_{16}$} & \multicolumn{2}{|c|}{$\mathrm{I}_{\text {eff }}$} & \multicolumn{2}{|c|}{$I_{16}$} & \multicolumn{2}{|c|}{$I_{\text {eff }}$} & \multicolumn{2}{|c|}{$\mathrm{I}_{\mathrm{b}}$} \\
\hline & $\mathrm{V}$ & NV & V & NV & $\mathrm{v}$ & NV & V & NV & $\mathrm{V}$ & NV & $\mathrm{V}$ & NV \\
\hline Mean & $\overline{1.01}$ & 0.86 & $\overline{1.13}$ & $\overline{0.98}$ & $\overline{0.84}$ & $\overline{0.68}$ & $\overline{0.97}$ & $\overline{0.81}$ & $\overline{0.87}$ & $\overline{0.72}$ & $1.0 \overline{0}$ & 0.84 \\
\hline Std. Dev. & 0.22 & 0.20 & 0.23 & 0.22 & 0.12 & 0.13 & 0.15 & 0.16 & 0.12 & 0.13 & 0.15 & 0.15 \\
\hline Coef. of Var. & 21.53 & 23.53 & 20.27 & 21.98 & 13.90 & 19.36 & 15.13 & 19.35 & 14.02 & 17.46 & 15.16 & 17.62 \\
\hline
\end{tabular}

Table 2. Summary of Models (deflection across the opening)

30 percent of ultimate load:

\begin{tabular}{|c|c|c|c|c|c|c|c|c|c|c|c|c|}
\hline & \multicolumn{4}{|c|}{ Model 1} & \multicolumn{4}{|c|}{ Model 2} & \multicolumn{4}{|c|}{ Model 3} \\
\hline & \multicolumn{2}{|c|}{$I_{\text {aff }}$} & \multicolumn{2}{|c|}{$I_{b b}$} & \multicolumn{2}{|c|}{$I_{\text {eff }}$} & \multicolumn{2}{|c|}{$I_{b}$} & \multicolumn{2}{|c|}{$I_{\text {eff }}$} & \multicolumn{2}{|c|}{$I_{\mathrm{fb}}$} \\
\hline & $\mathrm{V}$ & NV & V & NV & $\mathrm{V}$ & NV & V & NV & $\mathrm{V}$ & NV & V & NV \\
\hline Mean ${ }^{*}$ & 1.59 & $\overline{1.42}$ & 1.64 & $\overline{1.49}$ & $\overline{0.74}$ & $\overline{0.46}$ & $\overline{0.83}$ & $\overline{0.56}$ & $\overline{0.91}$ & $\overline{0.68}$ & $\overline{1.00}$ & $\overline{0.76}$ \\
\hline Std. Dev. & 0.88 & 0.82 & 0.91 & 0.83 & 0.31 & 0.21 & 0.34 & 0.25 & 0.41 & 0.31 & 0.44 & 0.35 \\
\hline Coef. of Var. & 54.93 & 57.72 & 55.27 & 55.99 & 41.77 & 44.99 & 41.02 & 44.16 & 44.30 & 45.81 & 43.71 & 46.20 \\
\hline
\end{tabular}

60 percent of ultimate load:

\begin{tabular}{|c|c|c|c|c|c|c|c|c|c|c|c|c|}
\hline & \multicolumn{4}{|c|}{ Model 1} & \multicolumn{4}{|c|}{ Model 2} & \multicolumn{4}{|c|}{ Model 3} \\
\hline & \multicolumn{2}{|c|}{$I_{\text {eff }}$} & \multicolumn{2}{|c|}{$\mathrm{I}_{\mathrm{b}}$} & \multicolumn{2}{|c|}{$I_{\text {eff }}$} & \multicolumn{2}{|c|}{$\mathrm{I}_{1 \mathrm{~b}}$} & \multicolumn{2}{|c|}{$I_{\text {eff }}$} & \multicolumn{2}{|c|}{$I_{1 b}$} \\
\hline & V & NV & V & NV & V & NV & $\mathrm{V}$ & NV & V & NV & $\mathrm{V}$ & NV \\
\hline Mean * & 1.15 & 1.08 & 1.24 & $\overline{1.13}$ & 0.58 & $\overline{0.37}$ & $\overline{0.65}$ & $\overline{0.45}$ & $\overline{0.71}$ & $\overline{0.52}$ & $\overline{0.77}$ & $\overline{0.59}$ \\
\hline Std. Dev. & $0.5 j$ & 0.51 & 0.58 & 0.53 & 0.27 & 0.18 & 0.30 & 0.22 & 0.32 & 0.24 & 0.35 & 0.28 \\
\hline Coef. of Var. & 47.74 & 47.68 & 46.55 & 46.76 & 45.81 & 50.30 & 45.46 & 49.12 & 44.89 & 46.59 & 45.06 & 47.11 \\
\hline
\end{tabular}

Model 1: Bending stiffness of the top tee neglects any contribution of the concrete slab.

Model 2: Bending stiffness of the top tee includes contribution of the concrete slab.

Model 3: Bending stiffness of top tee includes contribution of the concrete slab at the high moment end only. Calculated / Measured 
Table 3. Measured and calculated deflections across the opening for simplified version of Model 3, using $\mathrm{I}_{\mathrm{lb}}$

\begin{tabular}{|c|c|c|c|c|c|c|c|c|c|c|c|}
\hline \multirow[b]{4}{*}{ Test } & \multirow[b]{4}{*}{$\frac{M}{V d}$} & \multicolumn{5}{|c|}{ Deflection@30 percent of ultimate load } & \multicolumn{5}{|c|}{ Deflection @60 percent of ultimate load } \\
\hline & & \multicolumn{3}{|c|}{ Deflection (in.) } & \multicolumn{2}{|c|}{$\begin{array}{c}\text { Calc. - Meas. } \\
\text { ratio }\end{array}$} & \multicolumn{3}{|c|}{ Deflection (in.) } & \multicolumn{2}{|c|}{$\begin{array}{c}\text { Calc. - Meas. } \\
\text { ratio }\end{array}$} \\
\hline & & \multirow[b]{2}{*}{ meas. } & \multicolumn{2}{|c|}{ Calculated } & \multicolumn{2}{|c|}{ ** } & \multirow[b]{2}{*}{ meas. } & \multicolumn{2}{|c|}{ Calculated } & \multirow[b]{2}{*}{ V } & \multirow[b]{2}{*}{ NV } \\
\hline & & & $\mathrm{V}$ & NV & $\mathrm{V}$ & NV & & $\mathrm{V}$ & NV & & \\
\hline 1 & 2.04 & 0.065 & 0.056 & 0.045 & 0.86 & 0.70 & $\overline{0.170}$ & $\overline{0.112}$ & $\overline{0.091}$ & 0.66 & 0.53 \\
\hline 2 & 3.78 & 0.060 & 0.044 & 0.033 & 0.73 & 0.55 & 0.161 & 0.088 & 0.066 & 0.55 & 0.41 \\
\hline 3 & 26.30 & 0.052 & 0.013 & 0.009 & 0.24 & 0.17 & 0.088 & 0.025 & 0.018 & 0.28 & 0.20 \\
\hline $5 a$ & 3.78 & 0.052 & 0.042 & 0.032 & 0.80 & 0.62 & 0.127 & 0.084 & 0.064 & 0.66 & 0.50 \\
\hline $5 b$ & 3.78 & 0.081 & 0.045 & 0.032 & 0.55 & 0.39 & 0.214 & 0.089 & 0.063 & 0.42 & 0.30 \\
\hline $6 a$ & 0.00 & 0.047 & 0.038 & 0.027 & 0.81 & 0.57 & 0.149 & 0.076 & 0.053 & 0.51 & 0.36 \\
\hline $6 \mathrm{~b}$ & 2.04 & 0.066 & 0.062 & 0.048 & 0.93 & 0.73 & 0.162 & 0.123 & 0.096 & 0.76 & 0.59 \\
\hline $7 a$ & 2.04 & 0.061 & 0.067 & 0.055 & 1.10 & 0.90 & 0.150 & 0.134 & 0.110 & 0.89 & 0.74 \\
\hline $7 b$ & 3.78 & 0.061 & 0.059 & 0.047 & 0.96 & 0.77 & 0.130 & 0.117 & 0.094 & 0.90 & 0.72 \\
\hline $8 a$ & 3.89 & 0.033 & 0.029 & 0.020 & 0.87 & 0.61 & 0.090 & 0.057 & 0.040 & 0.64 & 0.45 \\
\hline $8 b$ & 2.90 & 0.028 & 0.051 & 0.039 & 1.82 & 1.40 & 0.102 & 0.102 & 0.078 & 1.00 & 0.77 \\
\hline $9 a$ & 2.04 & 0.055 & 0.055 & 0.041 & 1.00 & 0.74 & 0.174 & 0.110 & 0.081 & 0.63 & 0.47 \\
\hline $9 b$ & 1.75 & 0.046 & 0.031 & 0.020 & 0.68 & 0.42 & 0.130 & 0.062 & 0.039 & 0.48 & 0.30 \\
\hline $\mathrm{cl}$ & 6.00 & 0.051 & 0.064 & 0.049 & 1.26 & 0.96 & 0.034 & 0.128 & 0.098 & 3.78 & 2.89 \\
\hline c2 & 6.04 & 0.060 & 0.050 & 0.040 & 0.83 & 0.66 & 0.154 & 0.100 & 0.079 & 0.65 & 0.51 \\
\hline c3 & 22.15 & 0.028 & 0.025 & 0.021 & 0.91 & 0.76 & 0.073 & 0.051 & 0.043 & 0.70 & 0.58 \\
\hline $\mathrm{c} 4$ & 2.01 & 0.023 & 0.059 & 0.044 & 2.55 & 1.93 & 0.058 & 0.117 & 0.089 & 2.02 & 1.53 \\
\hline $\mathrm{c} 5$ & 3.97 & 0.059 & 0.062 & 0.049 & 1.05 & 0.84 & 0.139 & 0.123 & 0.099 & 0.89 & 0.71 \\
\hline c6 & 2.57 & 0.048 & 0.053 & 0.040 & 1.11 & 0.83 & 0.116 & 0.106 & 0.080 & 0.92 & 0.69 \\
\hline ro & 3.94 & 0.031 & 0.039 & 0.030 & 1.25 & 0.96 & 0.062 & 0.078 & 0.059 & 1.25 & 0.96 \\
\hline$n 1$ & 2.66 & 0.038 & 0.033 & 0.024 & 0.88 & 0.62 & 0.115 & 0.067 & 0.047 & 0.58 & 0.41 \\
\hline 12 & 7.00 & 0.047 & 0.033 & 0.022 & 0.70 & 0.48 & 0.096 & 0.066 & 0.045 & 0.69 & 0.47 \\
\hline \multirow[t]{4}{*}{$\mathrm{r} 3$} & 16.83 & 0.017 & 0.007 & 0.001 & 0.39 & 0.06 & 0.033 & 0.013 & 0.002 & 0.40 & 0.06 \\
\hline & & & \multicolumn{2}{|c|}{ Mean } & 1.03 & 0.77 & \multicolumn{3}{|c|}{ Mean } & 0.79 & 0.60 \\
\hline & & & \multirow{2}{*}{\multicolumn{2}{|c|}{$\begin{array}{l}\text { Std. Dev. } \\
\text { Coef. of Var. }\end{array}$}} & 0.45 & 0.35 & \multirow{2}{*}{\multicolumn{3}{|c|}{$\begin{array}{l}\text { Std. Dev, } \\
\text { Coef. of Var. }\end{array}$}} & 0.35 & 0.28 \\
\hline & & & & & 43.48 & 45.32 & & & & 44.33 & 46.31 \\
\hline
\end{tabular}


Table 4. Case study for total deflection at the point of maximum moment $\left(\Delta_{\mathrm{m}}=\right.$ total deflection for perforated beam, $\Delta_{\mathrm{b}}=$ bending deflection for unperforated beam, $\Delta_{\mathrm{s}}=$ shear deflection for unperforated beam)

\begin{tabular}{|c|c|c|c|c|c|c|c|c|c|c|c|}
\hline \multirow[b]{2}{*}{$\frac{\mathrm{h}_{\mathrm{o}}}{\mathrm{d}}$} & \multirow[b]{2}{*}{$\frac{a_{0}}{h_{0}}$} & \multirow[b]{2}{*}{$\frac{L_{0}}{L_{b}}$} & \multicolumn{3}{|c|}{ W $24 \times 55$} & \multicolumn{3}{|c|}{ W $18 \times 35$} & \multicolumn{3}{|c|}{ W $14 \times 22$} \\
\hline & & & $\Delta$ & $\frac{\Delta_{\mathrm{b}}}{\Delta_{\mathrm{b}}}$ & $\frac{\Delta_{0}}{\Delta_{b}+\Delta_{t}}$ & $\Delta_{m}$ & $\frac{\Delta_{m}}{\Delta_{b}}$ & $\frac{\Delta_{m}}{\Delta_{s}+\Delta_{s}}$ & $\Delta_{m}$ & $\frac{\Delta_{n}}{\Delta_{b}}$ & $\frac{\Delta_{\mathrm{m}}}{\Delta_{\mathrm{b}}+\Delta_{\mathrm{x}}}$ \\
\hline \multirow[t]{15}{*}{0.3} & 1 & $1 / 16$ & 1.080 & 1.038 & 1.001 & 0.897 & 1.047 & 1.001 & 0.512 & 1.069 & 1.001 \\
\hline & & $1 / 8$ & 1.081 & 1.039 & 1.001 & 0.898 & 1.048 & 1.002 & 0.512 & 1.070 & 1.002 \\
\hline & & $1 / 4$ & 1.084 & 1.041 & 1.004 & 0.900 & 1.051 & 1.004 & $0.5: 4$ & 1.073 & 1.005 \\
\hline & & $3 / 8$ & 1.087 & 1.044 & 1.007 & 0.903 & 1.054 & 1.008 & 0.516 & 1.077 & 1.009 \\
\hline & & $1 / 2$ & 1.090 & 1.047 & 1.009 & 0.906 & 1.057 & 1.010 & 0.517 & 1.080 & 1.012 \\
\hline & 2 & $1 / 16$ & 1.082 & 1.039 & 1.002 & 0.898 & 1.048 & 1.002 & 0.513 & 1.071 & 1.003 \\
\hline & & $1 / 8$ & 1.083 & 1.041 & 1.003 & 0.900 & 1.050 & 1.004 & 0.514 & 1.074 & 1.006 \\
\hline & & $1 / 4$ & 1.088 & 1.045 & 1.008 & 0.904 & 1.055 & 1.009 & 0.517 & 1.079 & 1.011 \\
\hline & & $3 / 8$ & 1.094 & 1.051 & 1.014 & 0.910 & 1.062 & 1.015 & 0.520 & 1.087 & 1.018 \\
\hline & & $1 / 2$ & 1.100 & 1.057 & 1.019 & 0.915 & 1.068 & 1.021 & 0.524 & 1.093 & 1.024 \\
\hline & 3 & $1 / 16$ & 1.084 & 1.042 & 1.004 & 0.901 & 1.051 & 1.005 & 0.515 & 1.075 & 1.007 \\
\hline & & $1 / 8$ & 1.086 & 1.043 & 1.006 & 0.902 & 1.053 & 1.007 & 0.516 & 1.077 & 1.009 \\
\hline & & $1 / 4$ & 1.093 & 1.050 & 1.013 & 0.909 & 1.061 & 1.014 & 0.520 & 1.086 & 1.017 \\
\hline & & $3 / 8$ & 1.102 & 1.059 & 1.021 & 0.917 & 1.070 & 1.023 & 0.525 & 1.097 & 1.027 \\
\hline & & $1 / 2$ & 1.109 & 1.066 & 1.028 & 0.924 & 1.079 & 1.031 & 0.530 & 1.106 & 1.036 \\
\hline \multirow[t]{15}{*}{0.5} & 1 & $1 / 16$ & 1.083 & 1.040 & 1.003 & 0.900 & 1.050 & 1.004 & 0.514 & 1.073 & 1.005 \\
\hline & & $1 / 8$ & 1.084 & 1.042 & 1.005 & 0.901 & 1.051 & 1.005 & 0.515 & 1.075 & 1.007 \\
\hline & & $1 / 4$ & 1.090 & 1.047 & 1.010 & 0.906 & 1.057 & 1.010 & 0.518 & 1.081 & 1.012 \\
\hline & & $3 / 8$ & 1.097 & 1.054 & 1.016 & 0.912 & 1.064 & 1.017 & 0.521 & 1.089 & 1.020 \\
\hline & & $1 / 2$ & 1.103 & 1.060 & 1.022 & 0.917 & 1.070 & 1.023 & 0.525 & 1.095 & 1.026 \\
\hline & 2 & $1 / 16$ & 1.091 & 1.048 & 1.011 & 0.906 & 1.058 & 1.011 & 0.519 & 1.085 & 1.016 \\
\hline & & $1 / 8$ & 1.093 & 1.051 & 1.013 & 0.908 & 1.060 & 1.014 & 0.521 & 1.087 & 1.018 \\
\hline & & $1 / 4$ & 1.103 & 1.060 & 1.022 & 0.917 & 1.070 & 1.023 & 0.526 & 1.097 & 1.028 \\
\hline & & $3 / 8$ & 1.116 & 1.072 & 1.034 & 0.928 & 1.083 & 1.035 & 0.532 & 1.111 & 1.041 \\
\hline & & $1 / 2$ & 1.126 & 1.082 & 1.043 & 0.937 & 1.094 & 1.045 & 0.538 & 1.123 & 1.052 \\
\hline & 3 & $1 / 16$ & 1.107 & 1.063 & 1.025 & 0.918 & 1.072 & 1.024 & 0.528 & 1.103 & 1.033 \\
\hline & & $1 / 8$ & 1.109 & 1.065 & 1.027 & 0.920 & 1.074 & 1.027 & 0.529 & 1.105 & 1.035 \\
\hline & & $1 / 4$ & 1.120 & 1.076 & 1.038 & 0.931 & 1.087 & 1.039 & 0.535 & 1.118 & 1.047 \\
\hline & & $3 / 8$ & 1.136 & 1.092 & 1.053 & 0.946 & 1.104 & 1.055 & 0.544 & 1.136 & 1.064 \\
\hline & & $1 / 2$ & 1.149 & 1.104 & 1.064 & 0.957 & 1.117 & 1.068 & 0.551 & 1.150 & 1.077 \\
\hline \multirow[t]{17}{*}{0.7} & 1 & $1 / 16$ & 1.093 & 1.051 & 1.013 & 0.909 & 1.061 & 1.014 & 0.522 & 1.090 & 1.021 \\
\hline & & $1 / 8$ & 1.095 & 1.053 & 1.015 & 0.910 & 1.063 & 1.016 & 0.523 & 1.091 & 1.022 \\
\hline & & $1 / 4$ & 1.105 & 1.061 & 1.023 & 0.918 & 1.071 & 1.024 & 0.526 & 1.099 & 1.030 \\
\hline & & $3 / 8$ & 1.117 & 1.073 & 1.035 & 0.927 & 1.082 & 1.035 & 0.532 & 1.110 & 1.040 \\
\hline & & $1 / 2$ & 1.127 & 1.083 & 1.044 & 0.936 & 1.092 & 1.044 & 0.536 & 1.120 & 1.049 \\
\hline & 2 & $1 / 16$ & 1.129 & 1.085 & 1.046 & 0.935 & 1.091 & 1.043 & 0.541 & 1.130 & 1.059 \\
\hline & & $1 / 8$ & 1.130 & 1.086 & 1.047 & 0.936 & 1.092 & 1.044 & 0.541 & 1.130 & 1.059 \\
\hline & & $1 / 4$ & 1.142 & 1.097 & 1.058 & 0.947 & 1.105 & 1.056 & 0.546 & 1.141 & 1.069 \\
\hline & & $3 / 8$ & 1.160 & 1.115 & 1.075 & 0.962 & 1.123 & 1.074 & 0.555 & 1.158 & 1.085 \\
\hline & & $1 / 2$ & 1.173 & 1.127 & 1.087 & 0.974 & 1.136 & 1.086 & 0.561 & 1.171 & 1.097 \\
\hline & 3 & $1 / 16$ & 1.201 & 1.154 & 1.113 & 0.980 & 1.144 & 1.093 & 0.571 & 1.192 & 1.116 \\
\hline & & $1 / 8$ & 1.196 & 1.149 & 1.108 & 0.978 & 1.141 & 1.091 & 0.569 & 1.187 & 1.112 \\
\hline & & $1 / 4$ & 1.200 & 1.153 & 1.112 & 0.987 & 1.151 & 1.101 & 0.572 & 1.195 & 1.119 \\
\hline & & $3 / 8$ & 1.214 & 1.166 & 1.124 & 1.002 & 1.170 & 1.118 & 0.581 & 1.212 & 1.136 \\
\hline & & $1 / 2$ & 1.219 & 1.171 & 1.129 & 1.012 & 1.181 & 1.129 & 0.585 & 1.222 & 1.144 \\
\hline & & & \multicolumn{3}{|c|}{$\Delta_{b}=1.041$} & \multicolumn{3}{|c|}{$\Delta_{\mathrm{b}}=0.857$} & \multicolumn{3}{|c|}{$\Delta_{\mathrm{b}}=0.479$} \\
\hline & & & \multicolumn{3}{|c|}{$\Delta_{b}+\Delta_{t}=1.079$} & \multicolumn{3}{|c|}{$\Delta_{\mathrm{b}}+\Delta_{\mathrm{s}}=0.896$} & \multicolumn{3}{|c|}{$\Delta_{b}+\Delta_{z}=0.511$} \\
\hline
\end{tabular}


Table 5. Comparison of deflection, $\Delta_{y, b}^{(P)}$, calculated using Eq. 23 to the matrix solution

\begin{tabular}{|c|c|c|c|c|c|c|c|c|c|c|c|}
\hline \multirow[b]{3}{*}{$\frac{h_{0}}{d}$} & \multirow[b]{3}{*}{$\frac{a_{0}}{h_{0}}$} & \multirow[b]{3}{*}{$\frac{L_{n}}{L_{n}}$} & \multicolumn{3}{|c|}{ W $24 \times 55$} & \multicolumn{3}{|c|}{ W $18 \times 35$} & \multicolumn{3}{|c|}{ W $14 \times 22$} \\
\hline & & & \multicolumn{2}{|c|}{$\Delta_{y, b}^{(P)}$} & \multirow[b]{2}{*}{$\frac{\text { Eg. } 23}{\text { matrix soln. }}$} & \multicolumn{2}{|c|}{$\Delta_{y, b}^{(P)}$} & \multirow[b]{2}{*}{$\frac{\text { Eq. } 23}{\text { matrix soln. }}$} & \multicolumn{2}{|c|}{$\Delta_{y, b}^{(p)}$} & \multirow[b]{2}{*}{$\frac{\mathrm{Eq} .23}{\text { matrix soln. }}$} \\
\hline & & & Eq. 23 & $\begin{array}{l}\text { matrix } \\
\text { soln. }\end{array}$ & & Eq. 23 & $\begin{array}{l}\operatorname{matrix} \\
\text { soln. }\end{array}$ & & Eq. 23 & $\begin{array}{c}\text { matrix } \\
\text { soln. }\end{array}$ & \\
\hline \multirow[t]{12}{*}{0.3} & 1 & $1 / 16$ & -0.000302 & -0.000253 & 1.193 & -0.000236 & -0.000206 & 1.147 & -0.000176 & -0.000159 & 1.110 \\
\hline & & $1 / 8$ & -0.000258 & -0.000216 & 1.193 & -0.000202 & -0.000176 & 1.147 & -0.000151 & -0.000136 & 1.110 \\
\hline & & $1 / 4$ & -0.000170 & -0.000143 & 1.193 & -0.000133 & -0.000116 & 1.147 & -0.000099 & -0.000089 & 1.110 \\
\hline & & $3 / 8$ & -0.000082 & -0.000069 & 1.193 & -0.000065 & -0.000056 & 1.147 & -0.000048 & -0.000043 & 1.110 \\
\hline & 2 & $1 / 16$ & .0 .002370 & -0.001986 & 1.193 & -0.001857 & -0.001619 & 1.147 & -0.001385 & -0.001247 & 1.110 \\
\hline & & $1 / 8$ & -0.002019 & -0.001692 & 1.193 & -0.001582 & -0.001379 & 1.147 & -0.001179 & -0.001062 & 1.110 \\
\hline & & $1 / 4$ & -0.001318 & -0.001105 & 1.193 & -0.001033 & -0.000901 & 1.147 & -0.000768 & -0.000692 & 1.110 \\
\hline & & $3 / 8$ & -0.000617 & -0.000517 & 1.193 & -0.000484 & -0.000422 & 1.147 & -0.000357 & .0 .000322 & 1.110 \\
\hline & 3 & $1 / 16$ & -0.007855 & -0.006584 & 1.193 & -0.002636 & -0.002299 & 1.147 & -0.004582 & .0 .004126 & 1.110 \\
\hline & & $1 / 8$ & -0.006672 & .0 .005592 & 1.193 & -0.005230 & -0.004560 & 1.147 & -0.003889 & -0.003502 & 1.110 \\
\hline & & $1 / 4$ & -0.004305 & -0.003608 & 1.193 & -0.003377 & -0.002945 & 1.147 & -0.002502 & -0.002253 & 1.110 \\
\hline & & $3 / 8$ & -0.001938 & -0.001624 & 1.193 & -0.001525 & -0.001330 & 1.147 & -0.001115 & -0.001004 & 1.110 \\
\hline \multirow[t]{12}{*}{0.5} & 1 & $1 / 16$ & -0.002536 & -0.002272 & 1.116 & -0.001937 & -0.001797 & 1.078 & -0.001444 & -0.001372 & 1.052 \\
\hline & & $1 / 8$ & -0.002163 & -0.001938 & 1.116 & -0.001652 & -0.001533 & 1.078 & -0.001231 & -0.001170 & 1.052 \\
\hline & & $1 / 4$ & -0.001417 & -0.001270 & 1.116 & -0.001083 & -0.001005 & 1.078 & -0.000805 & -0.000765 & 1.052 \\
\hline & & $3 / 8$ & -0.000671 & -0.000601 & 1.116 & -0.000513 & -0.000476 & 1.078 & -0.000379 & -0.000360 & 1.052 \\
\hline & 2 & $1 / 16$ & -0.019687 & -0.017641 & 1.116 & -0.015046 & -0.013963 & 1.078 & $-0,011178$ & -0.010623 & 1.052 \\
\hline & & $1 / 8$ & -0.016703 & -0.014967 & 1.116 & -0.012769 & $\sim 0.011849$ & 1.078 & .0 .009475 & -0.009005 & 1.052 \\
\hline & & $1 / 4$ & -0.010734 & -0.009619 & 1.116 & -0.008214 & -0.007622 & 1.078 & -0.006069 & -0.005768 & 1.052 \\
\hline & & $3 / 8$ & -0.004766 & -0.004271 & 1.116 & -0.003659 & -0.003396 & 1.078 & -0.002663 & -0.002531 & 1.052 \\
\hline & 3 & $1 / 16$ & -0.064415 & $-0,057720$ & 1.116 & -0.049269 & -0.045722 & 1.078 & -0.036472 & -0.034662 & 1.052 \\
\hline & & $1 / 8$ & -0.054343 & -0.048695 & 1.116 & -0.041582 & -0.038589 & 1.078 & -0.030724 & -0.029200 & 1.052 \\
\hline & & $1 / 4$ & -0.034200 & -0.030645 & 1.116 & -0.026210 & -0.024323 & 1.078 & -0.019229 & -0.018275 & 1.052 \\
\hline & & $3 / 8$ & -0.014056 & -0.012595 & 1.116 & -0.010838 & -0.010057 & 1.078 & -0.007734 & -0.007351 & 1.052 \\
\hline \multirow[t]{12}{*}{0.7} & 1 & $1 / 16$ & -0.018420 & -0.017659 & 1.043 & -0.014786 & -0.014450 & 1.023 & -0.011822 & -0.011664 & 1.013 \\
\hline & & $1 / 8$ & -0.015678 & -0.015030 & 1.043 & -0.012587 & -0.012301 & 1.023 & -0.010056 & -0.009922 & 1.013 \\
\hline & & $1 / 4$ & -0.010194 & -0.009773 & 1.043 & -0.008190 & -0.008004 & 1.023 & -0.006524 & -0.006437 & 1.013 \\
\hline & & $3 / 8$ & .0 .004710 & -0.004516 & 1.043 & -0.003792 & -0.003706 & 1.023 & -0.002992 & -0.002953 & 1.013 \\
\hline & 2 & $1 / 16$ & -0.141173 & -0.135340 & 1.043 & -0.113444 & -0.110867 & 1.023 & -0.090259 & -0.089057 & 1.013 \\
\hline & & $1 / 8$ & -0.119238 & -0.114311 & 1.043 & -0.095854 & -0.093676 & 1.023 & -0.076132 & -0.075119 & 1.013 \\
\hline & & $1 / 4$ & -0.075368 & -0.072254 & 1.043 & -0.060674 & -0.059295 & 1.023 & -0.047879 & -0.047242 & 1.013 \\
\hline & & $3 / 8$ & -0.031497 & -0.030196 & 1.043 & -0.025494 & -0.024915 & 1.023 & -0.019626 & -0.019365 & 1.013 \\
\hline & 3 & $1 / 16$ & -0.455580 & -0.436756 & 1.043 & -0.366530 & -0.358201 & 1.023 & -0.290067 & -0.286204 & 1.013 \\
\hline & & $1 / 8$ & -0.381549 & -0.365784 & 1.043 & -0.307163 & -0.300183 & 1.023 & -0.242390 & -0.239162 & 1.013 \\
\hline & & $1 / 4$ & -0.233487 & -0.223839 & 1.043 & -0.188430 & -0.184148 & 1.023 & -0.147036 & -0.145078 & 1.013 \\
\hline & & $3 / 8$ & -0.085424 & -0.081895 & 1.043 & -0.069696 & -0.068113 & 1.023 & -0.051682 & -0.050994 & 1.013 \\
\hline
\end{tabular}


Table 6. Comparison of total deflection due to a shear load, $\Delta_{\mathrm{y}}^{(\mathrm{P})}$, with bending deflection due to shear load, $\Delta_{y, b}^{(P)}$

W $24 \times 55$

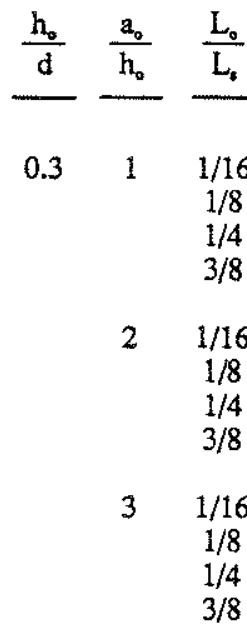

0.5

$\begin{array}{lll}.5 & 1 & 1 / 16 \\ & & 1 / 8 \\ & & 1 / 4 \\ & & 3 / 8\end{array}$

$2 \quad 1 / 16$

$1 / 8$

$3 / 8$

$31 / 16$

$1 / 8$

$3 / 8$

0.7

W $24 \times 55$

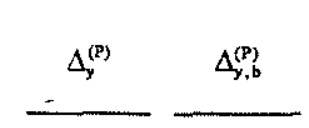

$\begin{array}{ll}-0.003157 & -0.000253\end{array}$

$-0.002698-0.000216$

$-0.001780-0.000143$

$-0.000862-0.000069$

$\begin{array}{lll}-0.007837 & -0.001986\end{array}$

$\begin{array}{ll}-0.006677 & -0.001693\end{array}$

$-0.004358-0.001105$

$\begin{array}{ll}-0.002039 & -0.000517\end{array}$

$-0.015418-0.006584$

$\begin{array}{ll}-0.013095 & -0.005592\end{array}$

$\begin{array}{lll}-0.008449 & -0.003608\end{array}$

$\begin{array}{lll}-0.003803 & -0.001624\end{array}$

$\begin{array}{ll}-0.009361 & -0.002272\end{array}$

$-0.007984-0.001938$

$\begin{array}{lll}-0.005230 & -0.001270\end{array}$

$\begin{array}{lll}-0.002476 & -0.000601\end{array}$

$\begin{array}{lll}-0.032424 & -0.017641\end{array}$

$\begin{array}{lll}-0.027509 & -0.014967\end{array}$

$\begin{array}{lll}-0.017679 & -0.009619\end{array}$

$\begin{array}{ll}-0.007849 & -0.004271\end{array}$

$\begin{array}{lll}-0.079963 & -0.057720\end{array}$

$\begin{array}{lll}-0.067460 & -0.048695\end{array}$

$\begin{array}{lll}-0.042455 & -0.030645\end{array}$

$\begin{array}{lll}-0.017449 & -0.012595\end{array}$

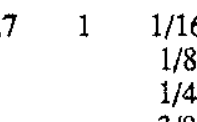

$1 / 8$
$1 / 4$

$3 / 8$

$2 \quad 1 / 16$

$1 / 8$

$1 / 4$

$3 / 8$

$3 \quad 1 / 16$

$1 / 16$
$1 / 8$
$1 / 4$
$3 / 8$ $\begin{array}{lll}-0.037223 & -0.017659\end{array}$

$\begin{array}{lll}-0.031683 & -0.015030\end{array}$

$\begin{array}{lll}-0.020601 & -0.009773\end{array}$

$\begin{array}{lll}-0.009519 & -0.004516\end{array}$

$\begin{array}{lll}-0.175642 & -0.135340\end{array}$

$-0.148351-0.114311$

$\begin{array}{ll}-0.093770 & -0.072254\end{array}$

$-0.039188-0.030196$

$\begin{array}{lll}-0.495632 & -0.436757\end{array}$

$\begin{array}{lll}-0.415092 & -0.365784\end{array}$

$-0.254013-0.223840$

$-0.092934-0.081895$
W $18 \times 35$

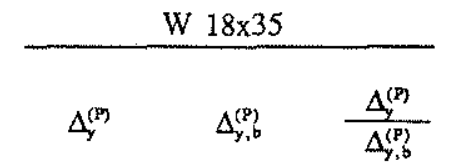

$\frac{\Delta_{y}^{(P)}}{\Delta_{y, b}^{(P)}}$

12.494

12.492

12.493

12.491

3.945

3.945

3.945

3.945

2.342

2.342

2.342

2.342

4.119

4.119

4.119

4.119

1.838

1.838

1.838

1.838

1.385

1.385

1.385

1.385

2.108

2.108

2.108

2.108

1.298

1.298

1.298

1.298

1.135

1.135

1.135

1.135

$\begin{array}{ccc}\Delta_{y}^{(\mathrm{P})} & \Delta_{y, b}^{(q)} & \frac{\Delta_{y}^{(q)}}{\Delta_{y, b}^{(p)}} \\ & & \\ -0.003109 & -0.000206 & 15.102 \\ -0.002658 & -0.000176 & 15.100 \\ -0.001754 & -0.000116 & 15.108 \\ -0.000850 & -0.000056 & 15.103 \\ & & \\ -0.007522 & -0.001619 & 4.647 \\ -0.006410 & -0.001380 & 4.647 \\ -0.004186 & -0.000901 & 4.647 \\ -0.001962 & -0.000422 & 4.646 \\ & & \\ -0.006156 & -0.002299 & 2.678 \\ -0.012212 & -0.004561 & 2.678 \\ -0.007886 & -0.002945 & 2.678 \\ -0.003560 & -0.001330 & 2.678\end{array}$

$\begin{array}{lll}-0.003560 & -0.001330\end{array}$

$\begin{array}{ll}-0.008994 & -0.001797\end{array}$

$-0.007672-0.001533$

$\begin{array}{ll}-0.005028 & -0.001005\end{array}$

$\begin{array}{ll}-0.002384 & -0.000476\end{array}$

$\begin{array}{ll}-0.029341 & -0.013963\end{array}$

$\begin{array}{ll}-0.024900 & -0.011849\end{array}$

$-0.016018-0.007623$

$\begin{array}{ll}-0.007136 & -0.003396\end{array}$

$\begin{array}{ll}-0.069175 & -0.045722\end{array}$

$\begin{array}{ll}-0.058384 & -0.038589\end{array}$

$-0.036800-0.024323$

$-0.015216-0.010057$

$\begin{array}{ll}-0.034588 & -0.014450\end{array}$

$-0.029444-0.012301$

$-0.019157-0.008004$

$-0.008871-0.003706$

$\begin{array}{ll}-0.152891 & -0.110867\end{array}$

$\begin{array}{ll}-0.129184 & -0.093676\end{array}$

$\begin{array}{ll}-0.081772 & -0.059296\end{array}$

$-0.034359-0.024915$

$\begin{array}{ll}-0.419863 & -0.358201\end{array}$

$\begin{array}{ll}-0.351858 & -0.300183\end{array}$

$\begin{array}{ll}-0.215848 & -0.184148\end{array}$

$-0.079838-0.068113$
5.004

5.004

5.004

5.004

2.101

2.101

2.101

2.101

1.513

1.513

1.513

1.513

2.394

2.394

2.394

2.394

1.379

1.379

1.379

1.379

1.172

1.172

1.172

1.172

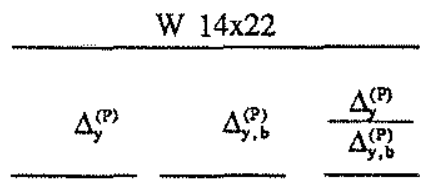

$\begin{array}{ll}-0.002799 & -0.000159\end{array}$

$-0.002392-0.000136$

$\begin{array}{lll}-0.001577 & -0.000089\end{array}$

$\begin{array}{lll}-0.000762 & -0.000043\end{array}$

17.617

17.613

17.619

17.620

$\begin{array}{lll}-0.006651 & -0.001247 & 5.334\end{array}$

$\begin{array}{lll}-0.005664 & -0.001062 & 5.334\end{array}$

$\begin{array}{lll}-0.003690 & -0.000692 & 5.334\end{array}$

$\begin{array}{lll}-0.001716 & -0.000322 & 5.333\end{array}$

$\begin{array}{lll}-0.012432 & -0.004126 & 3.013\end{array}$

$\begin{array}{lll}-0.010551 & -0.003502 & 3.013\end{array}$

$\begin{array}{lll}-0.006788 & -0.002253 & 3.013\end{array}$

$\begin{array}{lll}-0.003025 & -0.001004 & 3.013\end{array}$

$\begin{array}{lll}-0.007974 & -0.001372 & 5.812\end{array}$

$\begin{array}{lll}-0.006799 & -0.001170 & 5.812\end{array}$

$\begin{array}{lll}-0.004447 & -0.000765 & 5.812\end{array}$

$\begin{array}{lll}-0.002095 & -0.000361 & 5.812\end{array}$

$\begin{array}{lll}-0.024929 & -0.010623 & 2.347\end{array}$

$\begin{array}{lll}-0.021131 & -0.009005 & 2.347\end{array}$

$\begin{array}{lll}-0.013535 & -0.005768 & 2.347\end{array}$

$\begin{array}{lll}-0.005939 & -0.002531 & 2.347\end{array}$

$\begin{array}{lll}-0.056604 & -0.034662 & 1.633\end{array}$

$\begin{array}{lll}-0.047684 & -0.029200 & 1.633\end{array}$

$\begin{array}{lll}-0.029844 & -0.018275 & 1.633\end{array}$

$\begin{array}{lll}-0.012004 & -0.007351 & 1.633\end{array}$

$\begin{array}{lll}-0.030155 & -0.011664 & 2.585\end{array}$

$\begin{array}{lll}-0.025651 & -0.009922 & 2.585\end{array}$

$\begin{array}{lll}-0.016642 & -0.006437 & 2.585\end{array}$

$\begin{array}{lll}-0.007633 & -0.002953 & 2.585\end{array}$

$\begin{array}{lll}-0.127698 & -0.089057 & 1.434\end{array}$

$\begin{array}{lll}-0.107712 & -0.075119 & 1.434\end{array}$

$\begin{array}{lll}-0.067739 & -0.047242 & 1.434\end{array}$

$\begin{array}{lll}-0.027767 & -0.019365 & 1.434\end{array}$

$\begin{array}{lll}-0.342696 & -0.286204 & 1.197\end{array}$

$\begin{array}{lll}-0.286369 & -0.239162 & 1.197\end{array}$

$\begin{array}{lll}-0.173714 & -0.145078 & 1.197\end{array}$

$\begin{array}{lll}-0.061059 & -0.050994 & 1.197\end{array}$ 
Table 7. Comparison of shear deflection through the opening, $\Delta_{y, s}^{(P)}$, calculated using Eq. 26 to the matrix solution

\begin{tabular}{|c|c|c|c|c|c|c|c|c|c|c|c|}
\hline \multirow[b]{3}{*}{$\frac{h_{a}}{d}$} & \multirow[b]{3}{*}{$\frac{a_{a}}{h_{0}}$} & \multirow[b]{3}{*}{$\frac{\mathrm{L}_{0}}{\mathrm{~L}_{\mathrm{s}}}$} & \multicolumn{3}{|c|}{ W $24 \times 55$} & \multicolumn{3}{|c|}{$W 18 \times 35$} & \multicolumn{3}{|c|}{ W $14 \times 22$} \\
\hline & & & \multicolumn{2}{|c|}{$\Delta_{y, \mathrm{~g}}^{(\mathrm{P})}$} & \multirow[b]{2}{*}{$\frac{\text { Eq. } 26}{\text { matrix soln. }}$} & \multicolumn{2}{|c|}{$\Delta_{y, z}^{(p)}$} & \multirow[b]{2}{*}{$\frac{\text { Eq. } 26}{\text { matrix soln. }}$} & \multicolumn{2}{|c|}{$\Delta_{y, 1}^{(P)}$} & \multirow[b]{2}{*}{$\frac{\text { Eq. } 26}{\text { matrix soln }}$} \\
\hline & & & Eq. 26 & $\begin{array}{l}\text { matrix } \\
\text { soln. }\end{array}$ & & Eq. 26 & $\begin{array}{l}\text { matrix } \\
\text { soln. }\end{array}$ & & Eq. 26 & $\begin{array}{l}\text { matrix } \\
\text { soln. }\end{array}$ & \\
\hline 0.3 & 1 & $\begin{array}{c}1 / 16 \\
1 / 8 \\
1 / 4 \\
3 / 8\end{array}$ & $\begin{array}{l}-0.002949 \\
-0.002520 \\
-0.001663 \\
-0.000806\end{array}$ & $\begin{array}{l}-0.002904 \\
-0.002482 \\
-0.001638 \\
-0.000793\end{array}$ & $\begin{array}{l}1.015 \\
1.015 \\
1.015 \\
1.015\end{array}$ & $\begin{array}{r}-0.002951 \\
-0.002522 \\
-0.001665 \\
-0.000807\end{array}$ & $\begin{array}{r}-0.002904 \\
-0.002482 \\
-0.001638 \\
-0.000794\end{array}$ & $\begin{array}{l}1.016 \\
1.016 \\
1.016 \\
1.016\end{array}$ & $\begin{array}{l}-0.002684 \\
-0.002293 \\
-0.001512 \\
-0.000730\end{array}$ & $\begin{array}{l}-0.002640 \\
-0.002256 \\
-0.001487 \\
-0.000718\end{array}$ & $\begin{array}{l}1.016 \\
1.016 \\
1.016 \\
1.016\end{array}$ \\
\hline & 2 & $\begin{array}{c}1 / 16 \\
1 / 8 \\
1 / 4 \\
3 / 8\end{array}$ & $\begin{array}{l}-0.006127 \\
-0.005221 \\
-0.003407 \\
-0.001594\end{array}$ & $\begin{array}{l}-0.005850 \\
-0.004985 \\
-0.003253 \\
-0.001522\end{array}$ & $\begin{array}{l}1.047 \\
1.047 \\
1.047 \\
1.047\end{array}$ & $\begin{array}{l}-0.006209 \\
-0.005291 \\
-0.003455 \\
-0.001619\end{array}$ & $\begin{array}{l}-0.005903 \\
-0.005030 \\
-0.003285 \\
-0.001540\end{array}$ & $\begin{array}{l}1.052 \\
1.052 \\
1.052 \\
1.052\end{array}$ & $\begin{array}{l}-0.005685 \\
-0.004841 \\
-0.003154 \\
-0.001467\end{array}$ & $\begin{array}{l}-0.005404 \\
-0.004602 \\
-0.002998 \\
-0.001394\end{array}$ & $\begin{array}{l}1.052 \\
1.052 \\
1.052 \\
1.052\end{array}$ \\
\hline & 3 & $\begin{array}{c}1 / 16 \\
1 / 8 \\
1 / 4 \\
3 / 8\end{array}$ & $\begin{array}{l}-0.009516 \\
-0.008082 \\
-0.005215 \\
-0.002348\end{array}$ & $\begin{array}{l}-0.008834 \\
-0.007503 \\
-0.004841 \\
-0.002179\end{array}$ & $\begin{array}{l}1.077 \\
1.077 \\
1.077 \\
1.077\end{array}$ & $\begin{array}{r}-0.004188 \\
-0.008308 \\
-0.005365 \\
-0.002422\end{array}$ & $\begin{array}{l}-0.003857 \\
-0.007651 \\
-0.004941 \\
-0.002231\end{array}$ & $\begin{array}{l}1.086 \\
1.086 \\
1.086 \\
1.086\end{array}$ & $\begin{array}{l}-0.009028 \\
-0.007662 \\
-0.004929 \\
-0.002196\end{array}$ & $\begin{array}{l}-0.008306 \\
-0.007049 \\
-0.004535 \\
-0.002021\end{array}$ & $\begin{array}{l}1.087 \\
1.087 \\
1.087 \\
1.087\end{array}$ \\
\hline 0.5 & 1 & $\begin{array}{l}1 / 16 \\
1 / 8 \\
1 / 4 \\
3 / 8\end{array}$ & $\begin{array}{l}-0.007522 \\
-0.006416 \\
-0.004203 \\
-0.001990\end{array}$ & $\begin{array}{l}-0.007089 \\
-0.006046 \\
-0.003961 \\
-0.001875\end{array}$ & $\begin{array}{l}1.061 \\
1.061 \\
1.061 \\
1.061\end{array}$ & $\begin{array}{l}-0.007619 \\
-0.006499 \\
-0.004260 \\
-0.002020\end{array}$ & $\begin{array}{l}-0.007196 \\
-0.006139 \\
-0.004023 \\
-0.001908\end{array}$ & $\begin{array}{l}1.059 \\
1.059 \\
1.059 \\
1.059\end{array}$ & $\begin{array}{l}-0.006962 \\
-0.005936 \\
-0.003883 \\
-0.001829\end{array}$ & $\begin{array}{l}-0.006602 \\
-0.005629 \\
-0.003682 \\
-0.001735\end{array}$ & $\begin{array}{l}1.055 \\
1.055 \\
1.055 \\
1.055\end{array}$ \\
\hline & 2 & $\begin{array}{l}1 / 16 \\
1 / 8 \\
1 / 4 \\
3 / 8\end{array}$ & $\begin{array}{l}-0.016541 \\
-0.014034 \\
-0.009019 \\
-0.004004\end{array}$ & $\begin{array}{l}-0.014783 \\
-0.012542 \\
-0.008060 \\
-0.003579\end{array}$ & $\begin{array}{l}1.119 \\
1.119 \\
1.119 \\
1.119\end{array}$ & $\begin{array}{l}-0.017169 \\
-0.014570 \\
-0.009373 \\
-0.004175\end{array}$ & $\begin{array}{l}-0.015379 \\
-0.013051 \\
-0.008395 \\
-0.003740\end{array}$ & $\begin{array}{l}1.116 \\
1.116 \\
1.116 \\
1.116\end{array}$ & $\begin{array}{l}-0.015861 \\
-0.013444 \\
-0.008611 \\
-0.003779\end{array}$ & $\begin{array}{l}-0.014306 \\
-0.012126 \\
-0.007767 \\
-0.003408\end{array}$ & $\begin{array}{l}1.109 \\
1.109 \\
1.109 \\
1.109\end{array}$ \\
\hline & 3 & $\begin{array}{l}1 / 16 \\
1 / 8 \\
1 / 4 \\
3 / 8\end{array}$ & $\begin{array}{l}-0.025445 \\
-0.021467 \\
-0.013510 \\
-0.005553\end{array}$ & $\begin{array}{r}-0.022243 \\
-0.018765 \\
-0.011810 \\
-0.004854\end{array}$ & $\begin{array}{l}1.144 \\
1.144 \\
1.144 \\
1.144\end{array}$ & $\begin{array}{r}-0.026786 \\
-0.022607 \\
-0.014250 \\
-0.005892\end{array}$ & $\begin{array}{l}-0.023454 \\
-0.019795 \\
-0.012477 \\
-0.005159\end{array}$ & $\begin{array}{l}1.142 \\
1.142 \\
1.142 \\
1.142\end{array}$ & $\begin{array}{l}-0.024863 \\
-0.020945 \\
-0.013109 \\
-0.005273\end{array}$ & $\begin{array}{l}-0.021942 \\
-0.018484 \\
-0.011569 \\
-0.004653\end{array}$ & $\begin{array}{l}1.133 \\
1.133 \\
1.133 \\
1.133\end{array}$ \\
\hline 0.7 & 1 & $\begin{array}{l}1 / 16 \\
1 / 8 \\
1 / 4 \\
3 / 8\end{array}$ & $\begin{array}{l}-0.021768 \\
-0.018528 \\
-0.012047 \\
-0.005567\end{array}$ & $\begin{array}{l}-0.019564 \\
-0.016652 \\
-0.010828 \\
-0.005003\end{array}$ & $\begin{array}{l}1.113 \\
1.113 \\
1.113 \\
1.113\end{array}$ & $\begin{array}{l}-0.022159 \\
-0.018864 \\
-0.012273 \\
-0.005683\end{array}$ & $\begin{array}{l}-0.020138 \\
-0.017143 \\
-0.011154 \\
-0.005165\end{array}$ & $\begin{array}{l}1.100 \\
1.100 \\
1.100 \\
1.100\end{array}$ & $\begin{array}{l}-0.020213 \\
-0.017194 \\
-0.011155 \\
-0.005117\end{array}$ & $\begin{array}{l}-0.018491 \\
-0.015729 \\
-0.010205 \\
-0.004681\end{array}$ & $\begin{array}{l}1.093 \\
1.093 \\
1.093 \\
1.093\end{array}$ \\
\hline & 2 & $\begin{array}{l}1 / 16 \\
1 / 8 \\
1 / 4 \\
3 / 8\end{array}$ & $\begin{array}{l}-0.045939 \\
-0.038801 \\
-0.024525 \\
-0.010249\end{array}$ & $\begin{array}{l}-0.040302 \\
-0.034040 \\
-0.021516 \\
-0.008992\end{array}$ & $\begin{array}{l}1.140 \\
1.140 \\
1.140 \\
1.140\end{array}$ & $\begin{array}{r}-0.047283 \\
-0.039951 \\
-0.025289 \\
-0.010626\end{array}$ & $\begin{array}{l}-0.042024 \\
-0.035508 \\
-0.022476 \\
-0.009444\end{array}$ & $\begin{array}{l}1.125 \\
1.125 \\
1.125 \\
1.125\end{array}$ & $\begin{array}{r}-0.043137 \\
-0.036385 \\
-0.022883 \\
-0.009380\end{array}$ & $\begin{array}{l}-0.038641 \\
-0.032593 \\
-0.020498 \\
-0.008402\end{array}$ & $\begin{array}{l}1.116 \\
1.116 \\
1.116 \\
1.116\end{array}$ \\
\hline & 3 & $\begin{array}{l}1 / 16 \\
1 / 8 \\
1 / 4 \\
3 / 8\end{array}$ & $\begin{array}{l}-0.067494 \\
-0.056527 \\
-0.034591 \\
-0.012656\end{array}$ & $\begin{array}{l}-0.058875 \\
-0.049308 \\
-0.030174 \\
-0.011040\end{array}$ & $\begin{array}{l}1.146 \\
1.146 \\
1.146 \\
1.146\end{array}$ & $\begin{array}{l}-0.069747 \\
-0.058450 \\
-0.035856 \\
-0.013263\end{array}$ & $\begin{array}{l}-0.061662 \\
-0.051675 \\
-0.031700 \\
-0.011725\end{array}$ & $\begin{array}{l}1.131 \\
1.131 \\
1.131 \\
1.131\end{array}$ & $\begin{array}{l}-0.063384 \\
-0.052966 \\
-0.032130 \\
-0.011293\end{array}$ & $\begin{array}{l}-0.056492 \\
-0.047207 \\
-0.028636 \\
-0.010065\end{array}$ & $\begin{array}{l}1.122 \\
1.122 \\
1.122 \\
1.122\end{array}$ \\
\hline
\end{tabular}


Table 8. Comparison of deflection, $\Delta_{y, b}^{(M)}$, calculated using Eq. 31 to the matrix solution

\begin{tabular}{|c|c|c|c|c|c|c|c|c|c|c|c|}
\hline \multirow[b]{3}{*}{$\frac{h_{0}}{d}$} & \multirow[b]{3}{*}{$\frac{a_{0}}{h_{0}}$} & \multirow[b]{3}{*}{$\underline{L_{n}}$} & \multicolumn{3}{|c|}{ W $24 \times 55$} & \multicolumn{3}{|c|}{ W $18 \times 35$} & \multicolumn{3}{|c|}{$W 14 \times 22$} \\
\hline & & & \multicolumn{2}{|c|}{$\Delta_{y, b}^{M}$} & \multirow[b]{2}{*}{$\frac{\mathrm{Eg} \cdot 31}{\text { matrix soln. }}$} & \multicolumn{2}{|c|}{$\Delta_{y, b}^{(M)}$} & \multirow[b]{2}{*}{$\frac{\text { Eq. } 31}{\text { matrix soln. }}$} & \multicolumn{2}{|c|}{$\Delta_{y, b}^{(M)}$} & \multirow[b]{2}{*}{$\frac{\text { Eq. } 31}{\text { matrix soln }}$} \\
\hline & & & Eq. 31 & $\begin{array}{c}\text { matrix } \\
\text { soln. }\end{array}$ & & Eq. 31 & $\begin{array}{c}\text { matrix } \\
\text { soln. }\end{array}$ & & Eq. 31 & $\begin{array}{c}\text { matrix } \\
\text { soln. }\end{array}$ & \\
\hline \multirow[t]{3}{*}{0.3} & 1 & $\begin{array}{c}1 / 16 \\
1 / 8 \\
1 / 4 \\
3 / 8\end{array}$ & $\begin{array}{l}0.000439 \\
0.000775 \\
0.001289 \\
0.001592\end{array}$ & $\begin{array}{l}0.000377 \\
0.000665 \\
0.001105 \\
0.001365\end{array}$ & $\begin{array}{l}1.166 \\
1.166 \\
1.166 \\
1.166\end{array}$ & $\begin{array}{l}0.000344 \\
0.000609 \\
0.001013 \\
0.001252\end{array}$ & $\begin{array}{l}0.000309 \\
0.000545 \\
0.000908 \\
0.001121\end{array}$ & $\begin{array}{l}1.116 \\
1.116 \\
1.116 \\
1.116\end{array}$ & $\begin{array}{l}0.000240 \\
0.000422 \\
0.000701 \\
0.000865\end{array}$ & $\begin{array}{l}0.000223 \\
0.000392 \\
0.000651 \\
0.000803\end{array}$ & $\begin{array}{l}1.077 \\
1.077 \\
1.077 \\
1.077\end{array}$ \\
\hline & 2 & $\begin{array}{l}1 / 16 \\
1 / 8 \\
1 / 4 \\
3 / 8\end{array}$ & $\begin{array}{l}0.001929 \\
0.003247 \\
0.005251 \\
0.006413\end{array}$ & $\begin{array}{l}0.001655 \\
0.002785 \\
0.004504 \\
0.005500\end{array}$ & $\begin{array}{l}1.166 \\
1.166 \\
1.166 \\
1.166\end{array}$ & $\begin{array}{l}0.001511 \\
0.002549 \\
0.004127 \\
0.005043\end{array}$ & $\begin{array}{l}0.001354 \\
0.002283 \\
0.003697 \\
0.004517\end{array}$ & $\begin{array}{l}1.116 \\
1.116 \\
1.116 \\
1.116\end{array}$ & $\begin{array}{l}0.001063 \\
0.001777 \\
0.002860 \\
0.003486\end{array}$ & $\begin{array}{l}0.000987 \\
0.001650 \\
0.002656 \\
0.003238\end{array}$ & $\begin{array}{l}1.077 \\
1.077 \\
1.077 \\
1.077\end{array}$ \\
\hline & 3 & $\begin{array}{l}1 / 16 \\
1 / 8 \\
1 / 4 \\
3 / 8\end{array}$ & $\begin{array}{l}0.004725 \\
0.007633 \\
0.012027 \\
0.014526\end{array}$ & $\begin{array}{l}0.004052 \\
0.006546 \\
0.010315 \\
0.012459\end{array}$ & $\begin{array}{l}1.166 \\
1.166 \\
1.166 \\
1.166\end{array}$ & $\begin{array}{l}0.010417 \\
0.005986 \\
0.009449 \\
0.011421\end{array}$ & $\begin{array}{l}0.009331 \\
0.005362 \\
0.008464 \\
0.010231\end{array}$ & $\begin{array}{l}1.116 \\
1.116 \\
1.116 \\
1.116\end{array}$ & $\begin{array}{l}0.002617 \\
0.004188 \\
0.006559 \\
0.007901\end{array}$ & $\begin{array}{l}0.002430 \\
0.003889 \\
0.006091 \\
0.007337\end{array}$ & $\begin{array}{l}1.077 \\
1.077 \\
1.077 \\
1.077\end{array}$ \\
\hline \multirow[t]{3}{*}{0.5} & 1 & $\begin{array}{l}1 / 16 \\
1 / 8 \\
1 / 4 \\
3 / 8\end{array}$ & $\begin{array}{l}0.001327 \\
0.002267 \\
0.003699 \\
0.004534\end{array}$ & $\begin{array}{l}0.001237 \\
0.002114 \\
0.003449 \\
0.004228\end{array}$ & $\begin{array}{l}1.072 \\
1.072 \\
1.072 \\
1.072\end{array}$ & $\begin{array}{l}0.001041 \\
0.001782 \\
0.002912 \\
0.003571\end{array}$ & $\begin{array}{l}0.001010 \\
0.001728 \\
0.002823 \\
0.003462\end{array}$ & $\begin{array}{l}1.031 \\
1.031 \\
1.031 \\
1.031\end{array}$ & $\begin{array}{l}0.000732 \\
0.001242 \\
0.002019 \\
0.002471\end{array}$ & $\begin{array}{l}0.000729 \\
0.001238 \\
0.002012 \\
0.002463\end{array}$ & $\begin{array}{l}1.003 \\
1.003 \\
1.003 \\
1.003\end{array}$ \\
\hline & 2 & $\begin{array}{l}1 / 16 \\
1 / 8 \\
1 / 4 \\
3 / 8\end{array}$ & $\begin{array}{l}0.006112 \\
0.009751 \\
0.015240 \\
0.018340\end{array}$ & $\begin{array}{l}0.005700 \\
0.009094 \\
0.014212 \\
0.017103\end{array}$ & $\begin{array}{l}1.072 \\
1.072 \\
1.072 \\
1.072\end{array}$ & $\begin{array}{l}0.004786 \\
0.007658 \\
0.011991 \\
0.014442\end{array}$ & $\begin{array}{l}0.004640 \\
0.007424 \\
0.011625 \\
0.014002\end{array}$ & $\begin{array}{l}1.031 \\
1.031 \\
1.031 \\
1.031\end{array}$ & $\begin{array}{l}0.003400 \\
0.005371 \\
0.008338 \\
0.010005\end{array}$ & $\begin{array}{l}0.003388 \\
0.005352 \\
0.008309 \\
0.009970\end{array}$ & $\begin{array}{l}1.003 \\
1.003 \\
1.003 \\
1.003\end{array}$ \\
\hline & 3 & $\begin{array}{l}1 / 16 \\
1 / 8 \\
1 / 4 \\
3 / 8\end{array}$ & $\begin{array}{l}0.015510 \\
0.023428 \\
0.035235 \\
0.041670\end{array}$ & $\begin{array}{l}0.014464 \\
0.021848 \\
0.032859 \\
0.038860\end{array}$ & $\begin{array}{l}1.072 \\
1.072 \\
1.072 \\
1.072\end{array}$ & $\begin{array}{l}0.012122 \\
0.018376 \\
0.027709 \\
0.032809\end{array}$ & $\begin{array}{l}0.011753 \\
0.017816 \\
0.026864 \\
0.031809\end{array}$ & $\begin{array}{l}1.031 \\
1.031 \\
1.031 \\
1.031\end{array}$ & $\begin{array}{l}0.008679 \\
0.012954 \\
0.019311 \\
0.022742\end{array}$ & $\begin{array}{l}0.008649 \\
0.012910 \\
0.019245 \\
0.022664\end{array}$ & $\begin{array}{l}1.003 \\
1.003 \\
1.003 \\
1.003\end{array}$ \\
\hline \multirow[t]{3}{*}{0.7} & 1 & $\begin{array}{l}1 / 16 \\
1 / 8 \\
1 / 4 \\
3 / 8\end{array}$ & $\begin{array}{l}0.002920 \\
0.004845 \\
0.007766 \\
0.009449\end{array}$ & $\begin{array}{l}0.003021 \\
0.005011 \\
0.008032 \\
0.009773\end{array}$ & $\begin{array}{l}0.967 \\
0.967 \\
0.967 \\
0.967\end{array}$ & $\begin{array}{l}0.002279 \\
0.003789 \\
0.006083 \\
0.007405\end{array}$ & $\begin{array}{l}0.002396 \\
0.003984 \\
0.006395 \\
0.007786\end{array}$ & $\begin{array}{l}0.951 \\
0.951 \\
0.951 \\
0.951\end{array}$ & $\begin{array}{l}0.001605 \\
0.002642 \\
0.004214 \\
0.005116\end{array}$ & $\begin{array}{l}0.001706 \\
0.002808 \\
0.004478 \\
0.005437\end{array}$ & $\begin{array}{l}0.941 \\
0.941 \\
0.941 \\
0.941\end{array}$ \\
\hline & 2 & $\begin{array}{l}1 / 16 \\
1 / 8 \\
1 / 4 \\
3 / 8\end{array}$ & $\begin{array}{l}0.013978 \\
0.021328 \\
0.032313 \\
0.038345\end{array}$ & $\begin{array}{l}0.014458 \\
0.022060 \\
0.033421 \\
0.039661\end{array}$ & $\begin{array}{l}0.967 \\
0.967 \\
0.967 \\
0.967\end{array}$ & $\begin{array}{l}0.010875 \\
0.016651 \\
0.025289 \\
0.030044\end{array}$ & $\begin{array}{l}0.011435 \\
0.017507 \\
0.026590 \\
0.031590\end{array}$ & $\begin{array}{l}0.951 \\
0.951 \\
0.951 \\
0.951\end{array}$ & $\begin{array}{l}0.007759 \\
0.011702 \\
0.017580 \\
0.020780\end{array}$ & $\begin{array}{l}0.008246 \\
0.012436 \\
0.018683 \\
0.022083\end{array}$ & $\begin{array}{l}0.941 \\
0.941 \\
0.941 \\
0.941\end{array}$ \\
\hline & 3 & $\begin{array}{c}1 / 16 \\
1 / 8 \\
1 / 4 \\
3 / 8\end{array}$ & $\begin{array}{l}0.036397 \\
0.052148 \\
0.075293 \\
0.087294\end{array}$ & $\begin{array}{l}0.037646 \\
0.053937 \\
0.077876 \\
0.090289\end{array}$ & $\begin{array}{l}0.967 \\
0.967 \\
0.967 \\
0.967\end{array}$ & $\begin{array}{l}0.028265 \\
0.040658 \\
0.058892 \\
0.068389\end{array}$ & $\begin{array}{l}0.029719 \\
0.042749 \\
0.061921 \\
0.071906\end{array}$ & $\begin{array}{l}0.951 \\
0.951 \\
0.951 \\
0.951\end{array}$ & $\begin{array}{l}0.020327 \\
0.028739 \\
0.041045 \\
0.047324\end{array}$ & $\begin{array}{l}0.021601 \\
0.030541 \\
0.043618 \\
0.050291\end{array}$ & $\begin{array}{l}0.941 \\
0.941 \\
0.941 \\
0.941\end{array}$ \\
\hline
\end{tabular}


Table 9. Comparison of total deflection due to a moment, $\Delta_{y}^{(M)}$, with bending deflection due to a moment, $\Delta_{y, b}^{(M)}$

\begin{tabular}{|c|c|c|}
\hline$\frac{h_{0}}{d}$ & $\frac{a_{o}}{h_{0}}$ & $\frac{L_{0}}{L_{r}}$ \\
\hline 0.3 & 1 & $\begin{array}{c}1 / 16 \\
1 / 8 \\
1 / 4 \\
3 / 8\end{array}$ \\
\hline & 2 & $\begin{array}{c}1 / 16 \\
1 / 8 \\
1 / 4 \\
3 / 8\end{array}$ \\
\hline & 3 & $\begin{array}{c}1 / 16 \\
1 / 8 \\
1 / 4 \\
3 / 8\end{array}$ \\
\hline
\end{tabular}

$0.511 / 16$

$1 / 8$

$3 / 8$

2. $1 / 16$

$1 / 8$

$1 / 4$

$31 / 16$

$1 / 8$

$3 / 8$

$0.7 \quad 1 \quad 1 / 16$

$1 / 8$

$1 / 4$

$3 / 8$

$21 / 16$

$1 / 8$

$1 / 4$

$3 / 8$

$31 / 16$

$1 / 8$

$1 / 4$
$3 / 8$
W $24 \times 55$

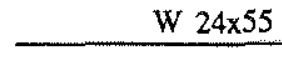

$\begin{array}{cccc}\Delta_{y}^{(M)} & \Delta_{y, b}^{(M)} & \frac{\Delta_{y}^{(M)}}{\Delta_{y, b}^{(M)}} \\ & & & \\ 0.000359 & 0.000377 & 0.955 \\ 0.000634 & 0.000665 & 0.955 \\ 0.001055 & 0.001105 & 0.955 \\ 0.001303 & 0.001365 & 0.955 \\ 0.001594 & 0.001655 & 0.963 \\ 0.002683 & 0.002785 & 0.963 \\ 0.004338 & 0.004504 & 0.963 \\ 0.005298 & 0.005502 & 0.963 \\ 0.003940 & 0.004052 & 0.972 \\ 0.006364 & 0.006546 & 0.972 \\ 0.010028 & 0.010315 & 0.972 \\ 0.012112 & 0.012459 & 0.972\end{array}$

$\begin{array}{ll}0.001174 & 0.001237\end{array}$

$\begin{array}{lll}0.002006 & 0.002114 & 0.949\end{array}$

0.003449

$0.004012 \quad 0.004228$

$\begin{array}{ll}0.005545 & 0.005700\end{array}$

$0.008846 \quad 0.009094$

$0.013825 \quad 0.014212$

$0.016637 \quad 0.017103$

$\begin{array}{ll}0.014242 & 0.014464\end{array}$

$\begin{array}{ll}0.021513 & 0.021848\end{array}$

$0.032356 \quad 0.032859$

$0.038265 \quad 0.038860$

$0.002911 \quad 0.003021$

$0.004829 \quad 0.005011$

$\begin{array}{ll}0.007740 & 0.008032\end{array}$

$0.009417 \quad 0.009773$

$0.014281 \quad 0.014458$

$0.021790 \quad 0.022060$

$0.033013 \quad 0.033421$

$0.039176 \quad 0.039661$

$0.037428 \quad 0.037646$

$\begin{array}{ll}0.053625 & 0.053937\end{array}$

$0.077425 \quad 0.077876$

0.089766

0.090289

\subsection{9}

0.949

0.949

0.973

0.973

0.973

0.973

0.985

0.985

0.985

0.985

\subsection{4}

0.964

0.964

0.964

0.988

0.988

0.988

0.988

0.994

0.994

0.994

0.994
W $18 \times 35$

$\longrightarrow$

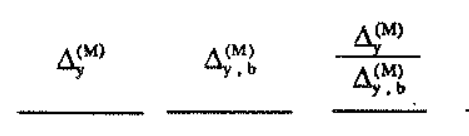

\section{$0.000290 \quad 0.000309$}

$0.000512 \quad 0.000545$

$\begin{array}{ll}0.000852 & 0.000908\end{array}$

$0.001052 \quad 0.001121$

$0.001285 \quad 0.001354$

$0.002167 \quad 0.002283$

$\begin{array}{ll}0.003509 & 0.003697\end{array}$

$0.004288 \quad 0.004517$

$\begin{array}{ll}0.008965 & 0.009331\end{array}$

$\begin{array}{ll}0.005152 & 0.005362\end{array}$

$\begin{array}{ll}0.008132 & 0.008464\end{array}$

$0.009829 \quad 0.010231$

$0.000943 \quad 0.001010$

$\begin{array}{lll}0.001613 & 0.001728\end{array}$

$0.002636 \quad 0.002823$

$0.003232 \quad 0.003462$

$\begin{array}{ll}0.004470 & 0.004640\end{array}$

$\begin{array}{ll}0.007152 & 0.007424\end{array}$

$0.011199 \quad 0.011625$

$\begin{array}{ll}0.013489 & 0.014002\end{array}$

$0.011506 \quad 0.011753$

$0.017442 \quad 0.017816$

$\begin{array}{ll}0.026301 & 0.026864\end{array}$

$0.031143 \quad 0.031809$

$\begin{array}{ll}0.002295 & 0.002396\end{array}$

$\begin{array}{lll}0.003817 & 0.003984\end{array}$

$0.006127 \quad 0.006395$

$0.007459 \quad 0.007786$

0.0112710 .011435

$\begin{array}{lll}0.017257 & 0.017507\end{array}$

$0.026210 \quad 0.026590$

$\begin{array}{ll}0.031138 & 0.031590\end{array}$

$\begin{array}{lll}0.029517 & 0.029719\end{array}$

$\begin{array}{ll}0.042458 & 0.042749\end{array}$

$0.061499 \quad 0.061921$

$0.071417 \quad 0.071906$
0.938

0.938

0.938

0.938

0.949

0.949

0.949

0.949

0.961

0.961

0.961

0.961

0.934

0.934

0.934

0.934

0.963

0.963

0.963

0.963

0.979

0.979

0.979

0.979

0.958

0.958

0.958

0.958

0.986

0.986

0.986

0.986

0.993

0.993

0.993

0.993

\begin{tabular}{|c|c|c|}
\hline$\Delta_{y}^{(M)}$ & $\Delta_{y, b}^{(M)}$ & $\frac{\Delta_{y}^{(M)}}{\Delta_{y, b}^{(M)}}$ \\
\hline 0.000206 & 0.000223 & 0.924 \\
\hline 0.000362 & 0.000392 & 0.924 \\
\hline 0.000601 & 0.000651 & 0.924 \\
\hline 0.000742 & 0.000803 & 0.924 \\
\hline 0.000925 & 0.000987 & 0.936 \\
\hline 0.001545 & 0.001650 & 0.936 \\
\hline 0.002487 & 0.002656 & 0.936 \\
\hline 0.003032 & 0.003238 & 0.936 \\
\hline 0.002309 & 0.002430 & 0.950 \\
\hline 0.003696 & 0.003889 & 0.950 \\
\hline 0.005788 & 0.006091 & 0.950 \\
\hline 0.006972 & 0.007337 & 0.950 \\
\hline
\end{tabular}

$\begin{array}{lll}0.000673 & 0.000729 & 0.923\end{array}$

$\begin{array}{lll}0.001142 & 0.001238 & 0.923\end{array}$

$\begin{array}{lll}0.018570 & 0.002012 & 9.228\end{array}$

$\begin{array}{lll}0.002273 & 0.002463 & 0.923\end{array}$

$\begin{array}{lll}0.003241 & 0.003388 & 0.957\end{array}$

$\begin{array}{lll}0.005120 & 0.005352 & 0.957\end{array}$

$\begin{array}{lll}0.007949 & 0.008309 & 0.957\end{array}$

$\begin{array}{lll}0.009538 & 0.009970 & 0.957\end{array}$

$\begin{array}{lll}0.008432 & 0.008649 & 0.975\end{array}$

$\begin{array}{lll}0.012586 & 0.012910 & 0.975\end{array}$

$\begin{array}{lll}0.018624 & 0.019245 & 0.968\end{array}$

$\begin{array}{lll}0.022096 & 0.022664 & 0.975\end{array}$

$\begin{array}{lll}0.001629 & 0.001706 & 0.955\end{array}$

$\begin{array}{lll}0.002682 & 0.002808 & 0.955\end{array}$

$\begin{array}{lll}0.004277 & 0.004478 & 0.955\end{array}$

$\begin{array}{lll}0.005192 & 0.005437 & 0.955\end{array}$

$\begin{array}{lll}0.008118 & 0.008246 & 0.985\end{array}$

$\begin{array}{lll}0.012244 & 0.012436 & 0.985\end{array}$

$\begin{array}{lll}0.018395 & 0.018683 & 0.985\end{array}$

$\begin{array}{lll}0.021742 & 0.022083 & 0.985\end{array}$

$\begin{array}{lll}0.021442 & 0.021601 & 0.993\end{array}$

$\begin{array}{lll}0.030317 & 0.030541 & 0.993\end{array}$

$\begin{array}{lll}0.043297 & 0.043618 & 0.993\end{array}$

$\begin{array}{lll}0.049921 & 0.050291 & 0.993\end{array}$ 
Table 10. Comparison of total deflection across an opening, $\Delta_{y}$, calculated using Eq. 32 to the matrix solution

\begin{tabular}{|c|c|c|c|c|c|c|c|c|c|c|c|}
\hline \multirow[b]{3}{*}{$\frac{h_{0}}{d}$} & \multirow[b]{3}{*}{$\frac{a_{0}}{h_{0}}$} & \multirow[b]{3}{*}{$\frac{\mathrm{L}_{0}}{\mathrm{~L}_{*}}$} & \multicolumn{3}{|c|}{ W $24 \times 55$} & \multicolumn{3}{|c|}{ W $18 \times 35$} & \multicolumn{3}{|c|}{ W $14 \times 22$} \\
\hline & & & \multicolumn{2}{|c|}{$\Delta_{y}$} & \multirow[b]{2}{*}{$\frac{\mathrm{Eq} \cdot 32}{\text { matrix soin. }}$} & \multicolumn{2}{|c|}{$\Delta_{y}$} & \multirow[b]{2}{*}{$\frac{\mathrm{Eq} \cdot 32}{\text { matrix soln. }}$} & \multicolumn{2}{|c|}{$\Delta_{y}$} & \multirow[b]{2}{*}{$\frac{\text { Eq. } 32}{\text { matrix soln. }}$} \\
\hline & & & Eq. 32 & $\begin{array}{l}\text { matrix } \\
\text { soln. }\end{array}$ & & Eq. 32 & $\begin{array}{l}\text { matrix } \\
\text { soln. }\end{array}$ & & Eq. 32 & $\begin{array}{l}\text { matrix } \\
\text { soln. }\end{array}$ & \\
\hline 0.3 & 1 & $\begin{array}{l}1 / 16 \\
1 / 8 \\
1 / 4 \\
3 / 8\end{array}$ & $\begin{array}{l}-0.048343 \\
-0.044809 \\
-0.033183 \\
-0.017292\end{array}$ & $\begin{array}{l}-0.048330 \\
-0.044869 \\
-0.033364 \\
-0.017556\end{array}$ & $\begin{array}{l}1.000 \\
0.999 \\
0.995 \\
0.985\end{array}$ & $\begin{array}{r}-0.039225 \\
-0.036315 \\
-0.026853 \\
-0.013983\end{array}$ & $\begin{array}{l}-0.039202 \\
-0.036346 \\
-0.026971 \\
-0.014161\end{array}$ & $\begin{array}{l}1.001 \\
0.999 \\
0.996 \\
0.987\end{array}$ & $\begin{array}{l}-0.024735 \\
-0.022821 \\
-0.016788 \\
-0.008690\end{array}$ & $\begin{array}{l}-0.024708 \\
-0.022830 \\
-0.016853 \\
-0.008796\end{array}$ & $\begin{array}{l}1.001 \\
1.000 \\
0.996 \\
0.988\end{array}$ \\
\hline & 2 & $\begin{array}{l}1 / 16 \\
1 / 8 \\
1 / 4 \\
3 / 8\end{array}$ & $\begin{array}{r}-0.098039 \\
-0.090450 \\
-0.066278 \\
-0.033734\end{array}$ & $\begin{array}{l}-0.097714 \\
-0.090452 \\
-0.066823 \\
-0.034677\end{array}$ & $\begin{array}{l}1.003 \\
1.000 \\
0.992 \\
0.973\end{array}$ & $\begin{array}{r}-0.079638 \\
-0.073385 \\
-0.053690 \\
-0.027304\end{array}$ & $\begin{array}{l}-0.079322 \\
-0.073304 \\
-0.054006 \\
-0.027917\end{array}$ & $\begin{array}{l}1.004 \\
1.001 \\
0.994 \\
0.978\end{array}$ & $\begin{array}{l}-0.050447 \\
-0.046286 \\
-0.033617 \\
-0.016911\end{array}$ & $\begin{array}{l}-0.050167 \\
-0.046161 \\
-0.033758 \\
-0.017258\end{array}$ & $\begin{array}{l}1.006 \\
1.003 \\
0.996 \\
0.980\end{array}$ \\
\hline & 3 & $\begin{array}{c}1 / 16 \\
1 / 8 \\
1 / 4 \\
3 / 8\end{array}$ & $\begin{array}{l}-0.150379 \\
-0.138003 \\
-0.099938 \\
-0.049554\end{array}$ & $\begin{array}{l}-0.149211 \\
-0.137612 \\
-0.100866 \\
-0.051486\end{array}$ & $\begin{array}{l}1.008 \\
1.003 \\
0.991 \\
0.962\end{array}$ & $\begin{array}{l}-0.065571 \\
-0.112080 \\
-0.081037 \\
-0.040147\end{array}$ & $\begin{array}{l}-0.066353 \\
-0.111587 \\
-0.081497 \\
-0.041351\end{array}$ & $\begin{array}{l}0.988 \\
1.004 \\
0.994 \\
0.971\end{array}$ & $\begin{array}{l}-0.077921 \\
-0.071045 \\
-0.050876 \\
-0.024787\end{array}$ & $\begin{array}{l}-0.077051 \\
-0.070538 \\
-0.051004 \\
-0.025429\end{array}$ & $\begin{array}{l}1.011 \\
1.007 \\
0.997 \\
0.975\end{array}$ \\
\hline 0.5 & 1 & $\begin{array}{l}1 / 16 \\
1 / 8 \\
1 / 4 \\
3 / 8\end{array}$ & $\begin{array}{l}-0.084850 \\
-0.078130 \\
-0.057170 \\
-0.029202\end{array}$ & $\begin{array}{l}-0.084305 \\
-0.077796 \\
-0.057206 \\
-0.029540\end{array}$ & $\begin{array}{l}1.006 \\
1.004 \\
0.999 \\
0.989\end{array}$ & $\begin{array}{r}-0.069334 \\
-0.063739 \\
-0.046542 \\
-0.023744\end{array}$ & $\begin{array}{l}-0.068870 \\
-0.063429 \\
-0.046504 \\
-0.023934\end{array}$ & $\begin{array}{l}1.007 \\
1.005 \\
1.001 \\
0.992\end{array}$ & $\begin{array}{r}-0.044653 \\
-0.040839 \\
-0.029577 \\
-0.014933\end{array}$ & $\begin{array}{l}-0.044280 \\
-0.040571 \\
-0.029499 \\
-0.015018\end{array}$ & $\begin{array}{l}1.008 \\
1.007 \\
1.003 \\
0.994\end{array}$ \\
\hline & 2 & $\begin{array}{c}1 / 16 \\
1 / 8 \\
1 / 4 \\
3 / 8\end{array}$ & $\begin{array}{r}-0.183326 \\
-0.166834 \\
-0.119159 \\
-0.057933\end{array}$ & $\begin{array}{l}-0.180089 \\
-0.164511 \\
-0.118500 \\
-0.058714\end{array}$ & $\begin{array}{l}1.018 \\
1.014 \\
1.006 \\
0.987\end{array}$ & $\begin{array}{r}-0.149834 \\
-0.136155 \\
-0.097059 \\
-0.047134\end{array}$ & $\begin{array}{l}-0.147276 \\
-0.134222 \\
-0.096282 \\
-0.047388\end{array}$ & $\begin{array}{l}1.017 \\
1.014 \\
1.008 \\
0.995\end{array}$ & $\begin{array}{l}-0.098090 \\
-0.088527 \\
-0.062330 \\
-0.029636\end{array}$ & $\begin{array}{r}-0.096139 \\
-0.086989 \\
-0.061573 \\
-0.029600\end{array}$ & $\begin{array}{l}1.020 \\
1.018 \\
1.012 \\
1.001\end{array}$ \\
\hline & 3 & $\begin{array}{l}1 / 16 \\
1 / 8 \\
1 / 4 \\
3 / 8\end{array}$ & $\begin{array}{r}-0.305217 \\
-0.274122 \\
-0.190420 \\
-0.087086\end{array}$ & $\begin{array}{r}-0.296587 \\
-0.267687 \\
-0.188045 \\
-0.088332\end{array}$ & $\begin{array}{l}1.029 \\
1.024 \\
1.013 \\
0.986\end{array}$ & $\begin{array}{r}-0.248380 \\
-0.222857 \\
-0.154622 \\
-0.070699\end{array}$ & $\begin{array}{l}-0.242116 \\
-0.217984 \\
-0.152369 \\
-0.070853\end{array}$ & $\begin{array}{l}1.026 \\
1.022 \\
1.015 \\
0.998\end{array}$ & $\begin{array}{l}-0.164840 \\
-0.146703 \\
-0.100123 \\
-0.044197\end{array}$ & $\begin{array}{r}-0.160356 \\
-0.143086 \\
-0.098177 \\
-0.043840\end{array}$ & $\begin{array}{l}1.028 \\
1.025 \\
1.020 \\
1.008\end{array}$ \\
\hline 0.7 & 1 & $\begin{array}{l}1 / 16 \\
1 / 8 \\
1 / 4 \\
3 / 8\end{array}$ & $\begin{array}{r}-0.144128 \\
-0.130544 \\
-0.092999 \\
-0.045839\end{array}$ & $\begin{array}{l}-0.141173 \\
-0.128037 \\
-0.091384 \\
-0.045113\end{array}$ & $\begin{array}{l}1.021 \\
1.020 \\
1.018 \\
1.016\end{array}$ & $\begin{array}{l}-0.120045 \\
-0.108480 \\
-0.077054 \\
-0.037941\end{array}$ & $\begin{array}{l}-0.117671 \\
-0.106446 \\
-0.075705 \\
-0.037283\end{array}$ & $\begin{array}{l}1.020 \\
1.019 \\
1.018 \\
1.018\end{array}$ & $\begin{array}{l}-0.082350 \\
-0.073820 \\
-0.051752 \\
-0.025057\end{array}$ & $\begin{array}{l}-0.080447 \\
-0.072182 \\
-0.050653 \\
-0.024505\end{array}$ & $\begin{array}{l}1.024 \\
1.023 \\
1.022 \\
1.023\end{array}$ \\
\hline & 2 & $\begin{array}{l}1 / 16 \\
1 / 8 \\
1 / 4 \\
3 / 8\end{array}$ & $\begin{array}{l}-0.388443 \\
-0.343141 \\
-0.232565 \\
-0.103809\end{array}$ & $\begin{array}{l}-0.376670 \\
-0.332991 \\
-0.225741 \\
-0.100419\end{array}$ & $\begin{array}{l}1.031 \\
1.030 \\
1.030 \\
1.034\end{array}$ & $\begin{array}{r}-0.321869 \\
-0.283980 \\
-0.192228 \\
-0.085926\end{array}$ & $\begin{array}{l}-0.313637 \\
-0.276753 \\
-0.187116 \\
-0.083071\end{array}$ & $\begin{array}{l}1.026 \\
1.026 \\
1.027 \\
1.034\end{array}$ & $\begin{array}{r}-0.230265 \\
-0.201335 \\
-0.133900 \\
-0.057797\end{array}$ & $\begin{array}{l}-0.224207 \\
-0.195987 \\
-0.130063 \\
-0.055596\end{array}$ & $\begin{array}{l}1.027 \\
1.027 \\
1.029 \\
1.040\end{array}$ \\
\hline & 3 & $\begin{array}{l}1 / 16 \\
1 / 8 \\
1 / 4 \\
3 / 8\end{array}$ & $\begin{array}{r}-0.810881 \\
-0.700674 \\
-0.451481 \\
-0.176588\end{array}$ & $\begin{array}{r}-0.782408 \\
-0.676214 \\
-0.435285 \\
-0.168971\end{array}$ & $\begin{array}{l}1.036 \\
1.036 \\
1.037 \\
1.045\end{array}$ & $\begin{array}{l}-0.667058 \\
-0.576220 \\
-0.371510 \\
-0.146216\end{array}$ & $\begin{array}{r}-0.649393 \\
-0.560665 \\
-0.360465 \\
-0.140067\end{array}$ & $\begin{array}{l}1.027 \\
1.028 \\
1.032 \\
1.044\end{array}$ & $\begin{array}{r}-0 .+90590 \\
-0.419967 \\
-0.265017 \\
-0.097947\end{array}$ & $\begin{array}{r}-0.478720 \\
-0.409403 \\
-0.257313 \\
-0.093434\end{array}$ & $\begin{array}{l}1.025 \\
1.026 \\
1.030 \\
1.048\end{array}$ \\
\hline
\end{tabular}


Table 11. Measured and calculated deflections across the opening using Model 3 and Eq. 32

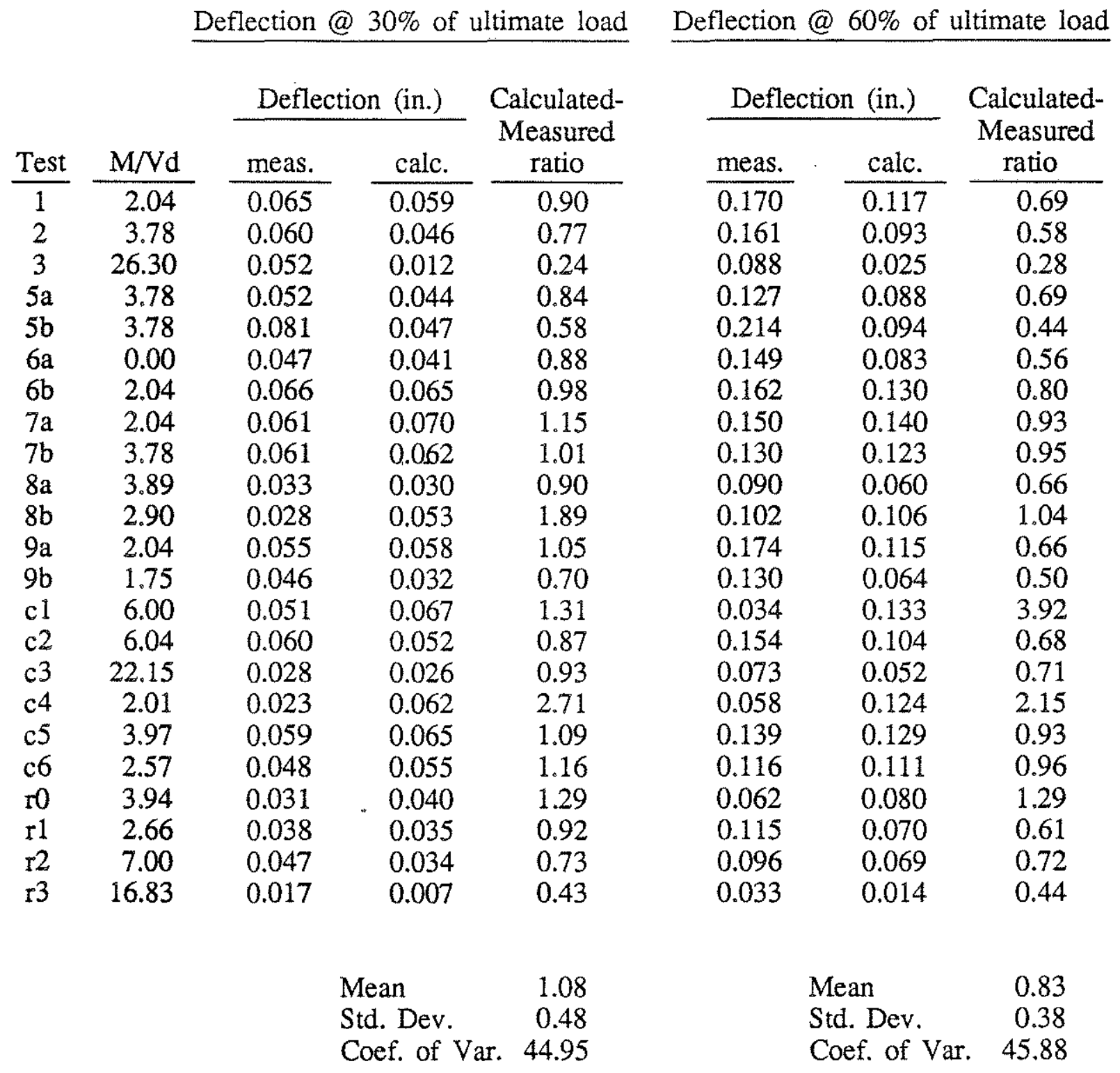




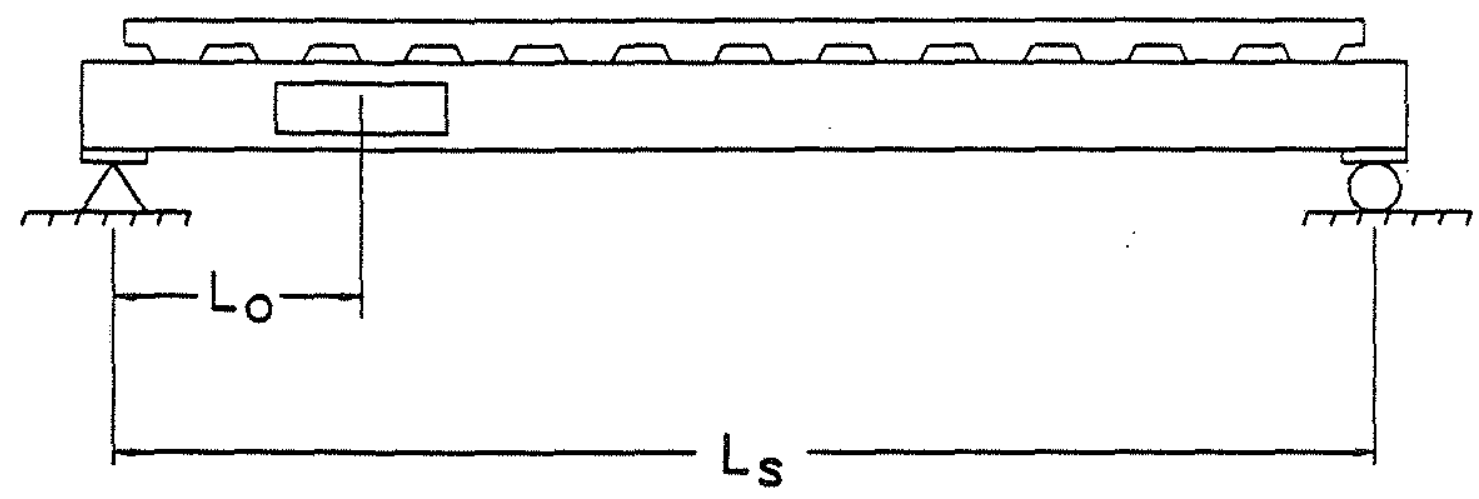

(a) Beam Schematic
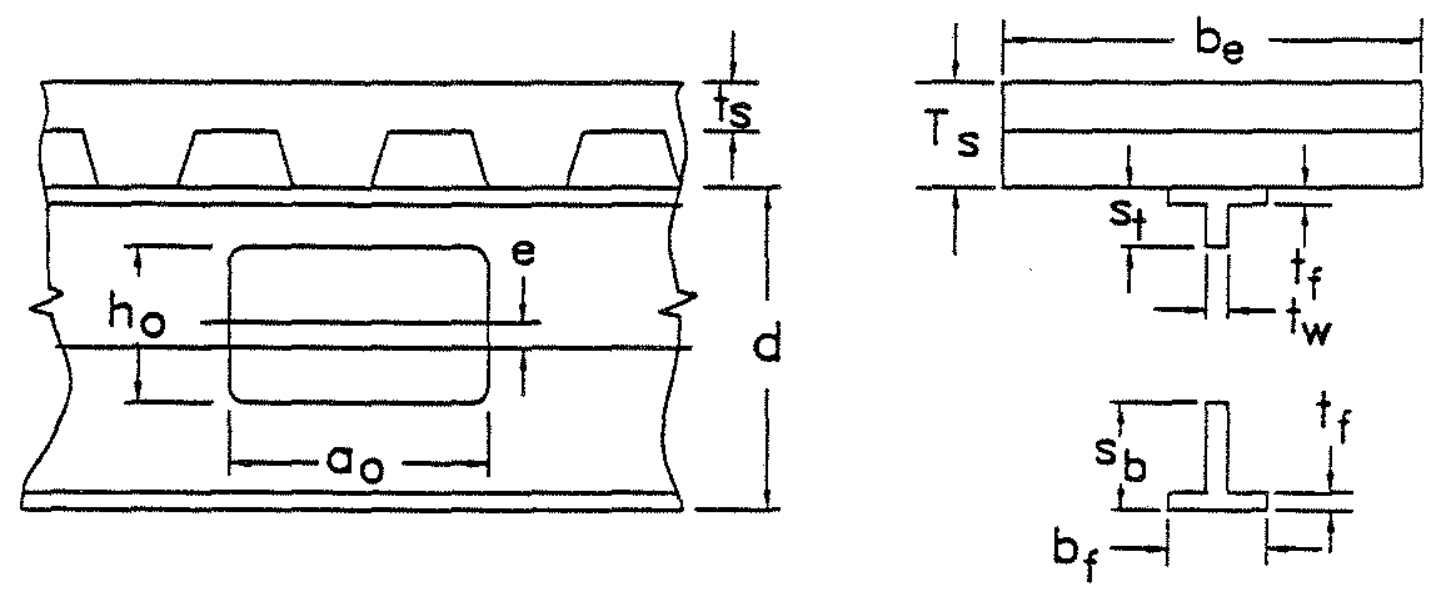

(b) Opening Detail

Fig. 1. Composite Beam With Web Opening (Donahey and Darwin 1986, Donahey 1987) 


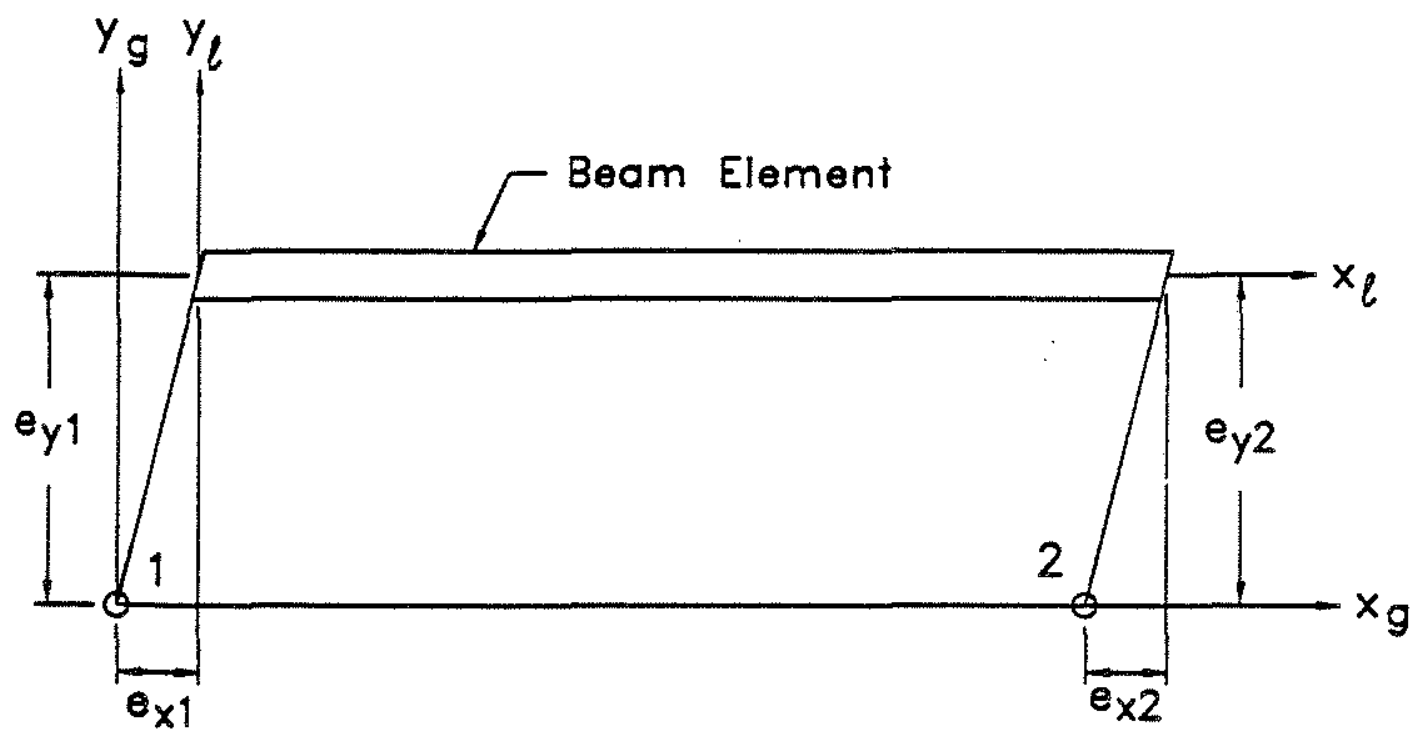

(a) Global and Local Axes

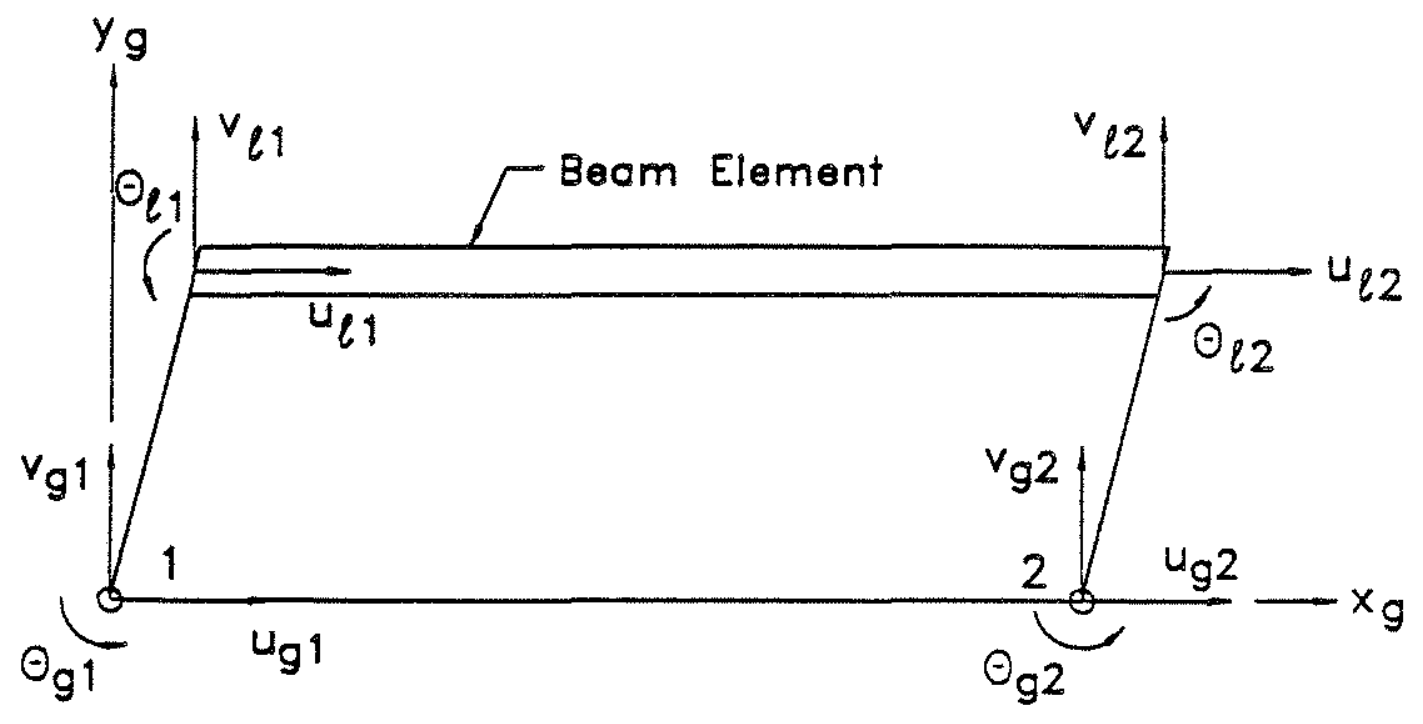

(b) Global and Local Degrees of Freedom

Fig. 2. Beam Element With Two Rigid Links (Donahey and Darwin 1986, Donahey 1987) 


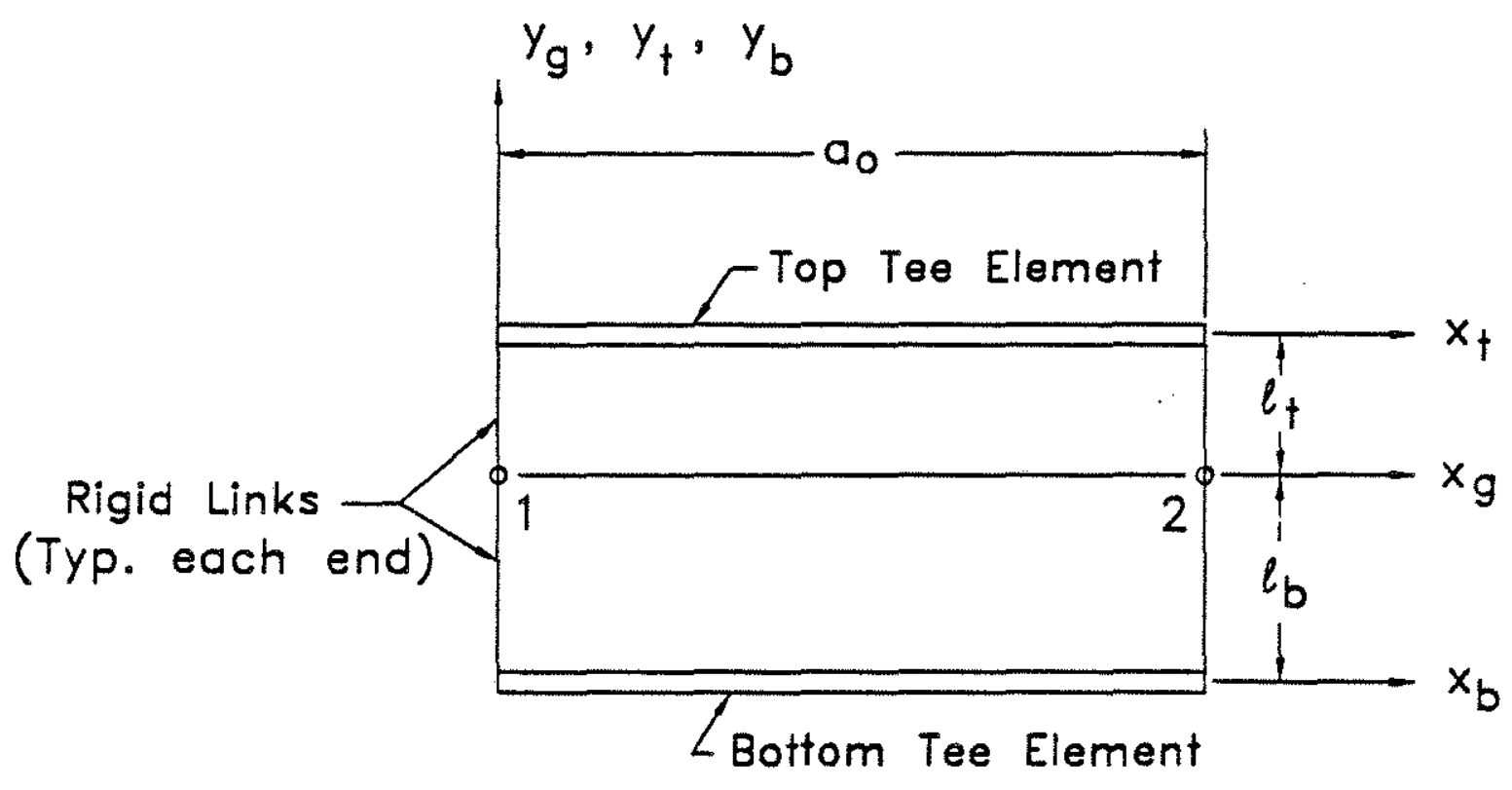

Fig. 3. Web Opening Element Geometry and Axes Orientations (Donahey and Darwin 1986, Donahey 1987)

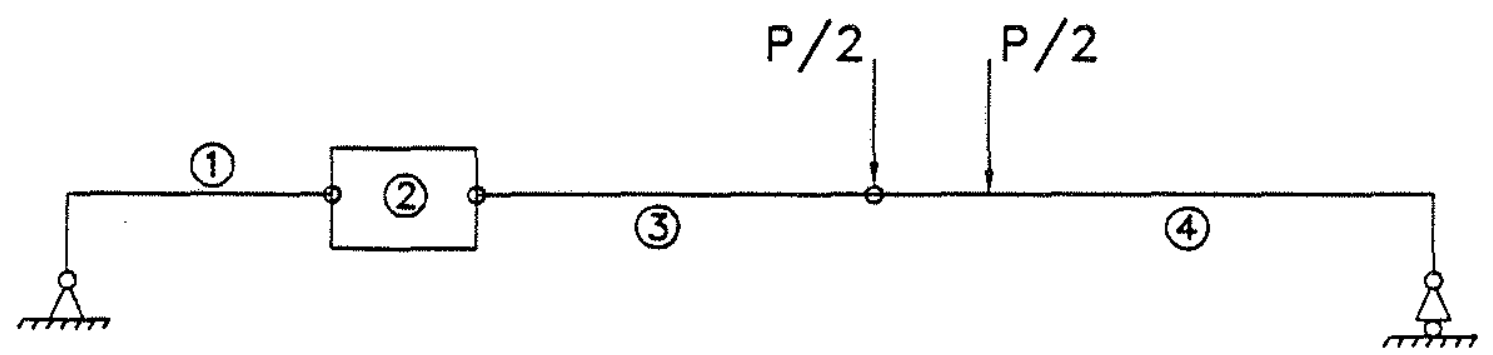

Fig. 4. Deflection Analysis Model for Beam With Web Opening (Parametric Study) (Donahey and Darwin 1986, Donahey 1987) 


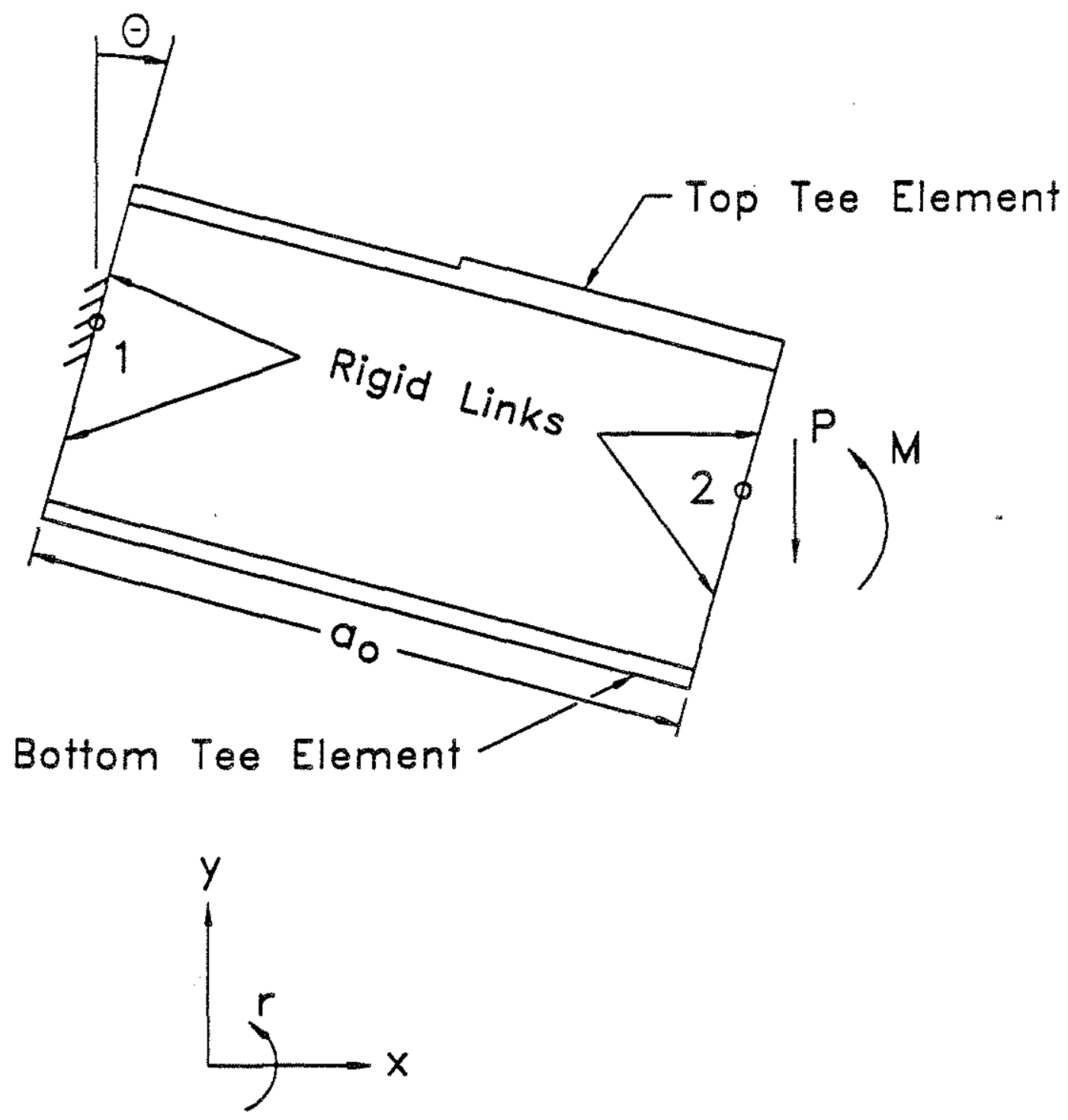

Fig. 5. Simplified Version of Model 3 


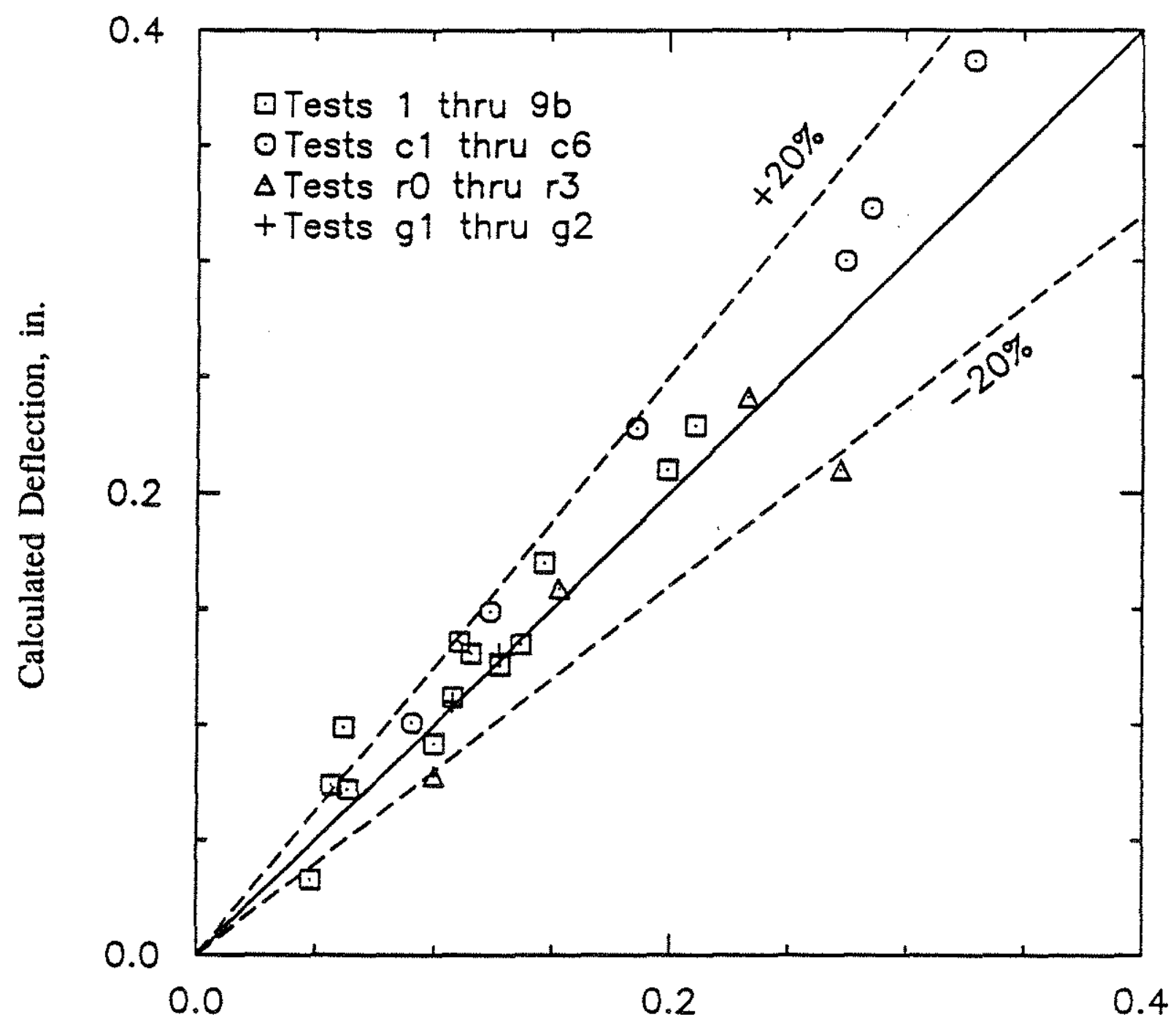

Measured Deflection, in.

Fig. 6. Calculated Versus Measured Deflection at Point of Maximum Moment Model 2, $\left(\mathrm{I}_{\mathrm{lb}}, \mathrm{V}\right)$, at $30 \%$ of Ultimate Load 


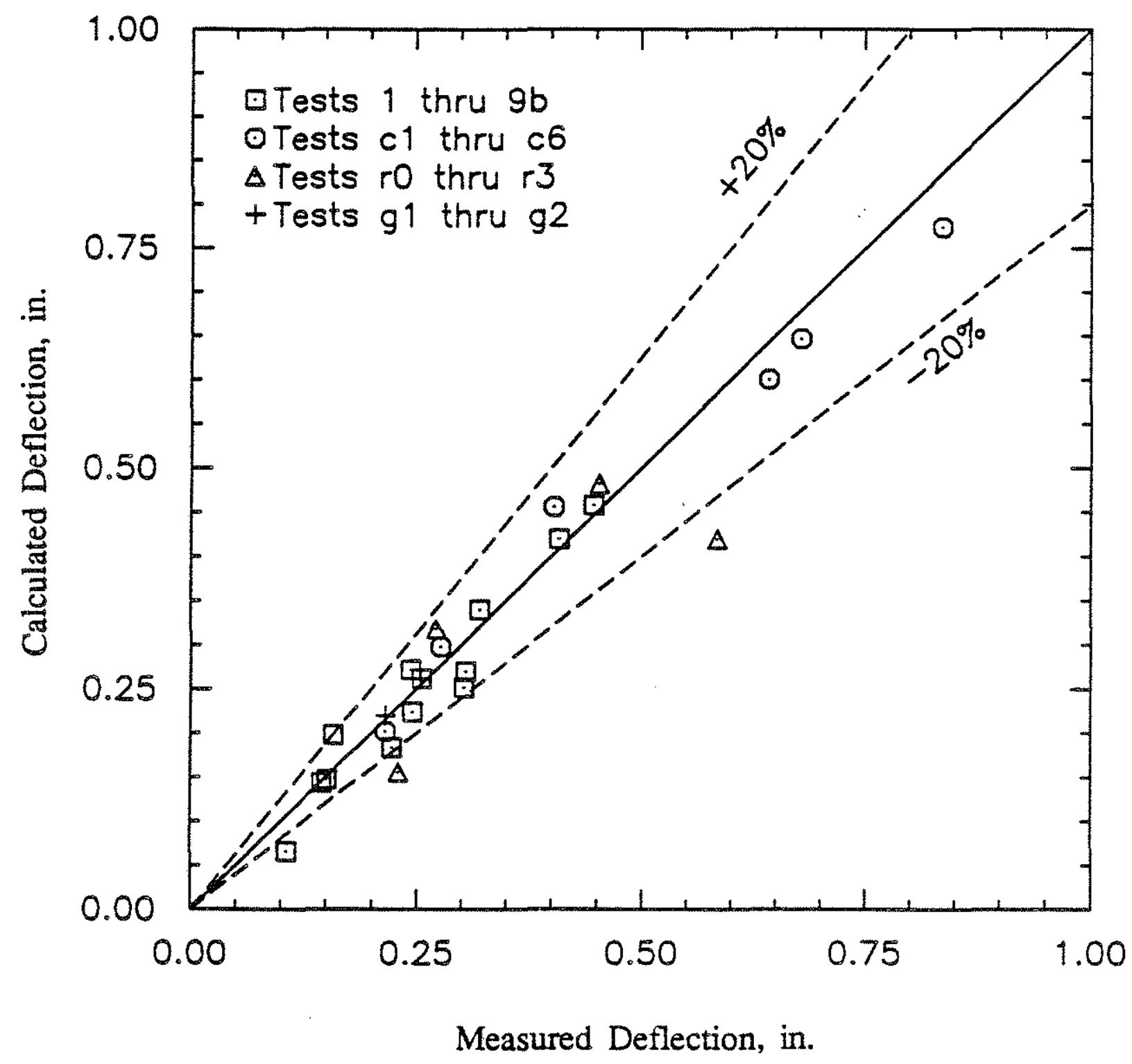

Fig. 7. Calculated Versus Measured Deflection at Point of Maximum Moment Model 2, $\left(\mathrm{I}_{\mathrm{lb}}, \mathrm{V}\right)$, at $60 \%$ of Ultimate Load 


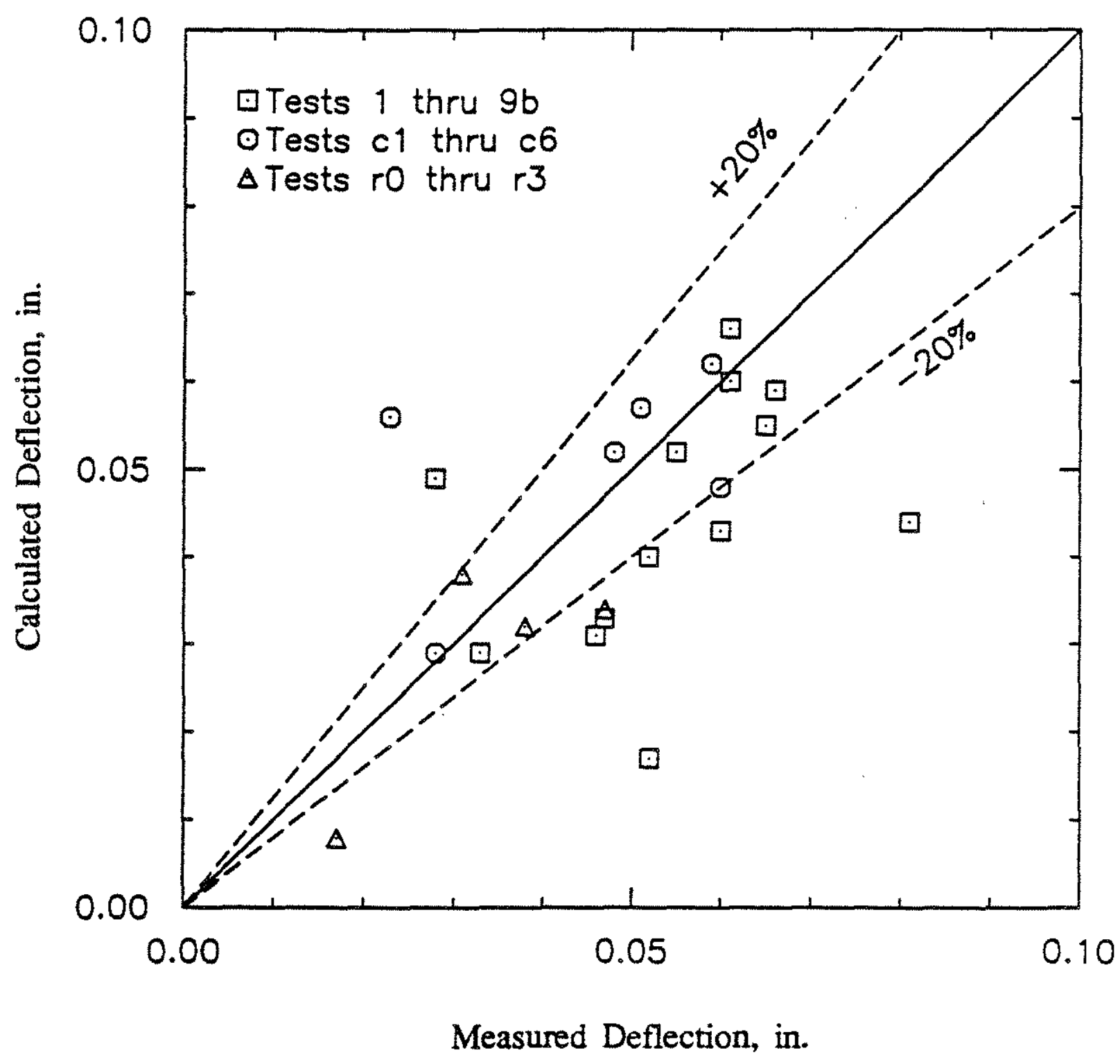

Fig. 8. Calculated Versus Measured Deflection Across the Opening Model 3, $\left(\mathrm{I}_{\mathrm{lb}}, \mathrm{V}\right)$, at $30 \%$ of Ultimate Load 


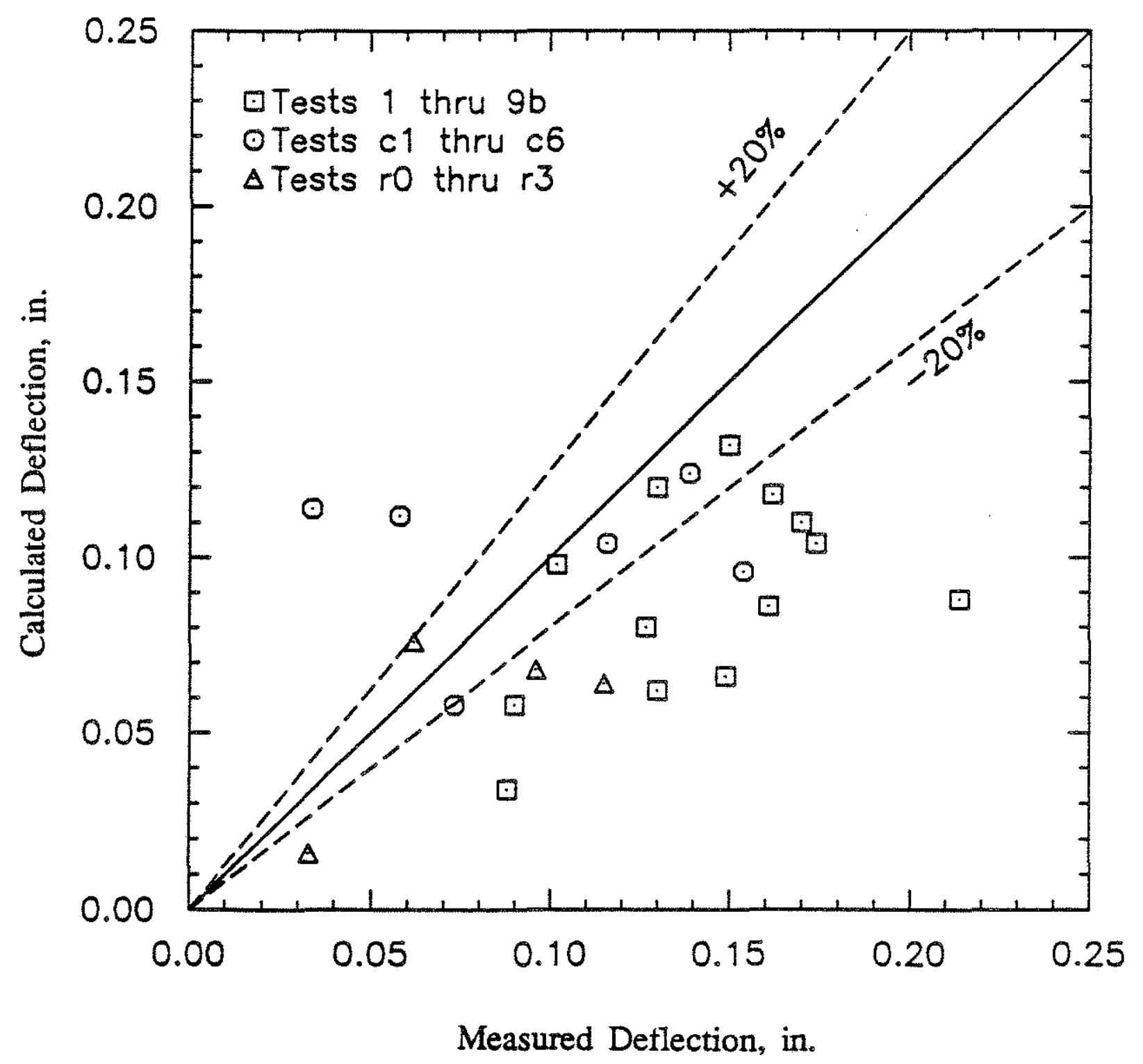

Fig. 9. Calculated Versus Measured Deflection Across the Opening Model 3, $\left(\mathrm{I}_{\mathrm{lb}}, \mathrm{V}\right)$, at $60 \%$ of Ultimate Load 


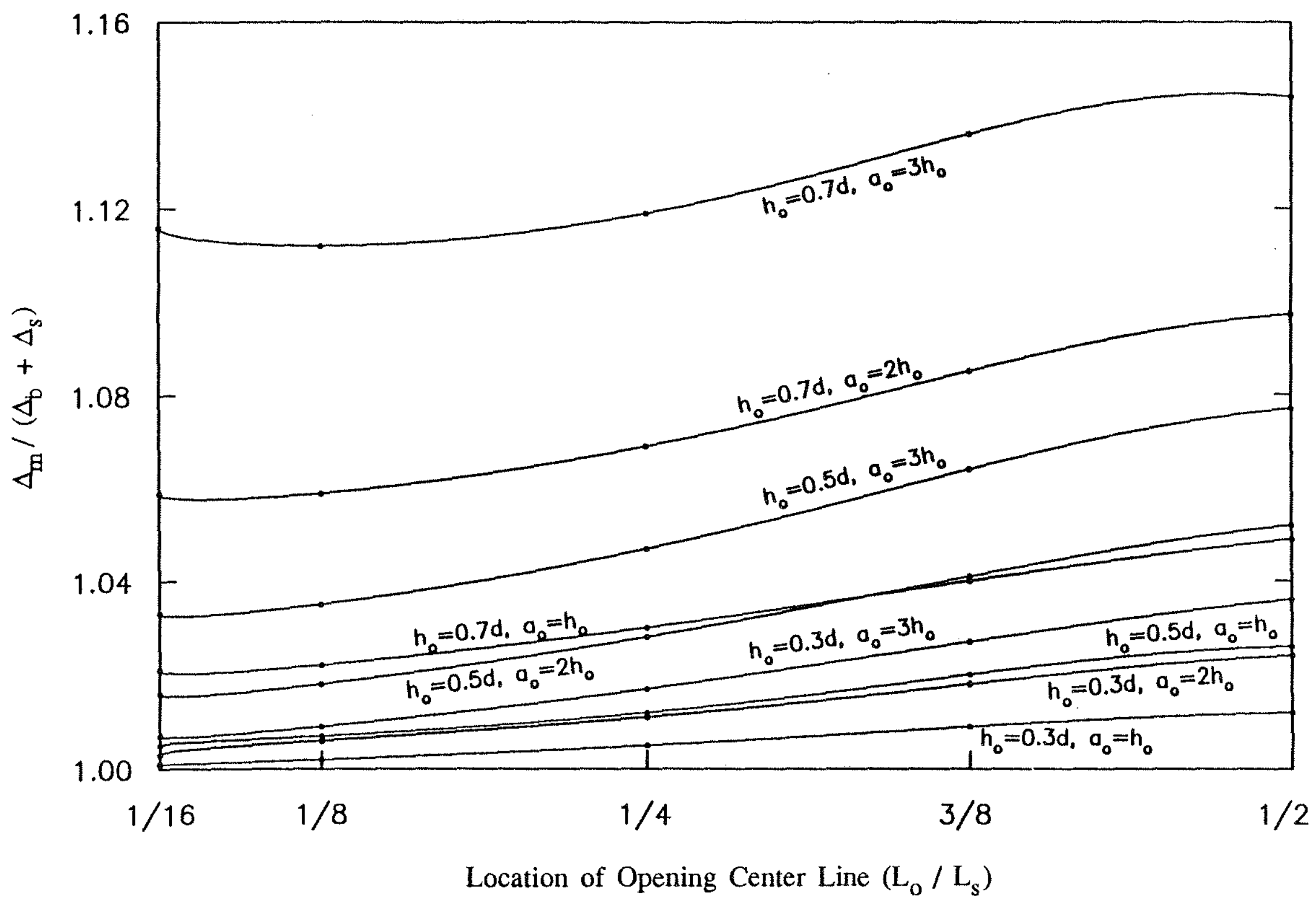

Fig. 10. Location of Opening Center Line Versus $\Delta_{\mathrm{m}} /\left(\Delta_{\mathrm{b}}+\Delta_{\mathrm{s}}\right)$ for the W14x22 


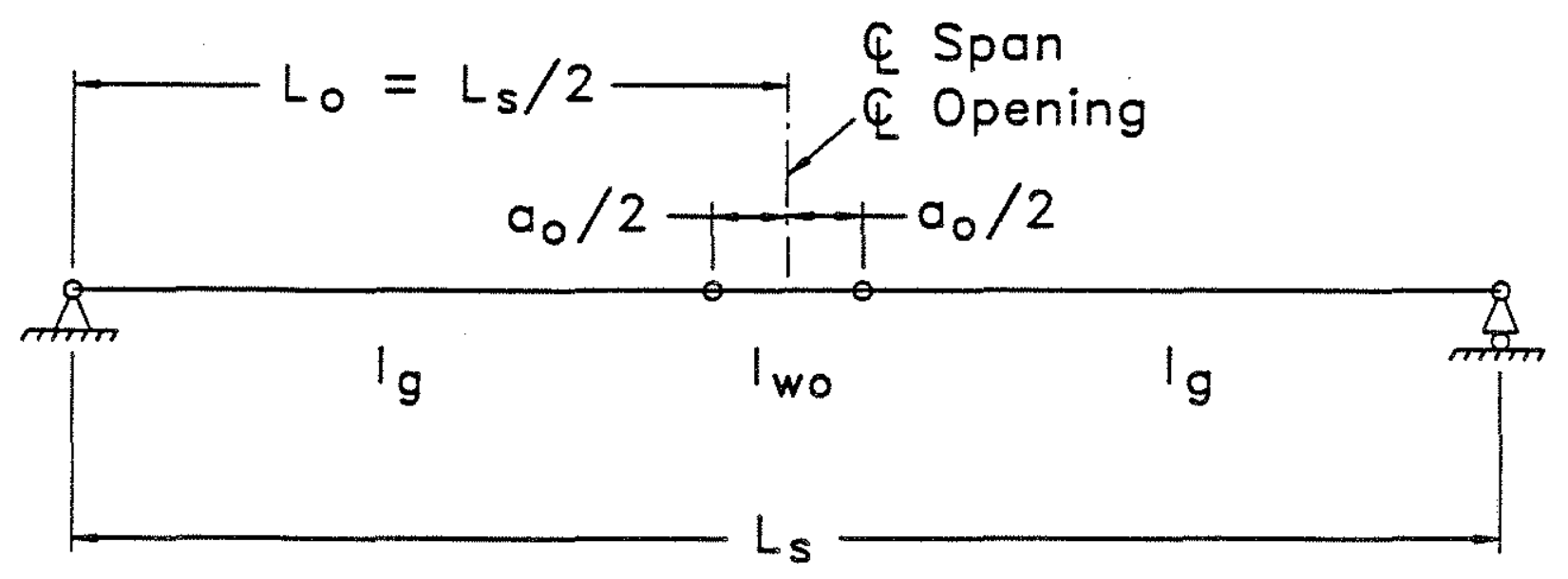

Fig. 11. Simplified Model To Obtain Maximum Bending Deflection 


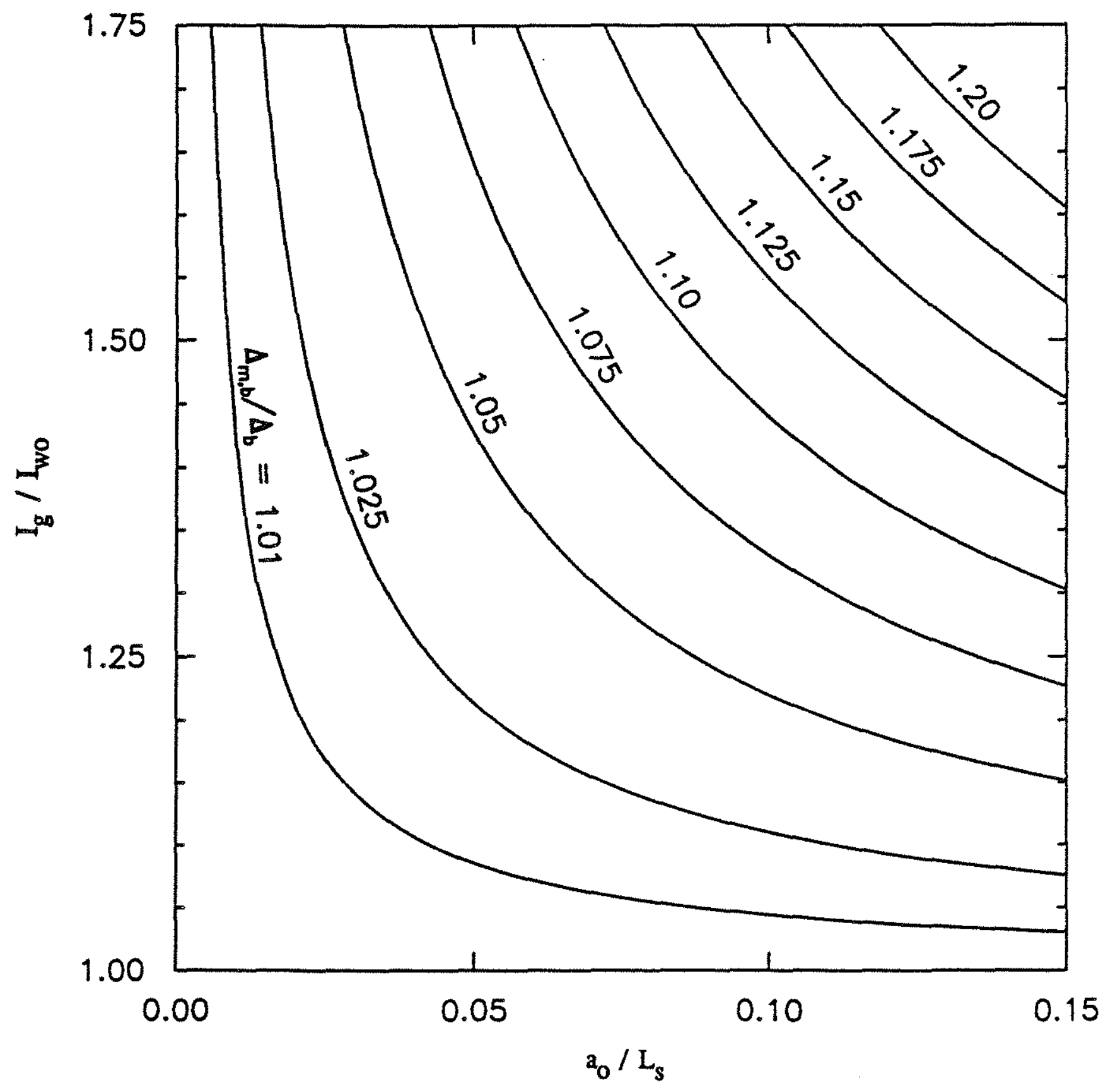

Fig. 12. Design Aid for Calculating Maximum Deflection in a Beam With a Web Opening

$\Delta_{\mathrm{m}, \mathrm{b}}=$ maximum bending deflection for the perforated beam, $\Delta_{\mathrm{b}}=$ maximum bending deflection for the unperforated beam, $a_{0}=$ opening length, $L_{s}=$ span length, $I_{g}=$ moment of inertia for unperforated sections, $\mathrm{I}_{\text {wo }}=$ the moment of inertia in the region of the web opening 
Table A1. Measured and calculated deflections for Model 1 using $\mathrm{I}_{\text {eff }}$ at $30 \%$ of ultimate load

\begin{tabular}{|c|c|c|c|c|c|c|}
\hline \multirow[b]{4}{*}{ Test } & \multirow[b]{4}{*}{$\frac{M}{V_{d}}$} & \multicolumn{5}{|c|}{ Deflection@ Point of Maximum Moment } \\
\hline & & \multicolumn{3}{|c|}{ Deflection (in.) } & \multicolumn{2}{|c|}{$\begin{array}{l}\text { Calc. - Meas. } \\
\text { ratio }\end{array}$} \\
\hline & & \multirow[b]{2}{*}{ meas. } & \multicolumn{2}{|c|}{ Calculated } & \multirow[b]{2}{*}{ V } & \multirow[b]{2}{*}{ NV } \\
\hline & & & $\mathrm{v}$ & NV & & \\
\hline 1 & 2.04 & $\overline{0.116}$ & $\overline{0.127}$ & $\overline{0.108}$ & 1.09 & 0.93 \\
\hline 2 & 3.78 & 0.137 & 0.134 & 0.115 & 0.98 & 0.84 \\
\hline 3 & 26.30 & $0.21 !$ & 0.207 & 0.183 & 0.98 & 0.87 \\
\hline $5 \mathrm{a}$ & 3.78 & 0.111 & 0.133 & 0.117 & 1.20 & 1.05 \\
\hline $5 b$ & 3.78 & 0.128 & 0.143 & 0.126 & 1.12 & 0.98 \\
\hline $6 a$ & 0.00 & 0,048 & 0.044 & 0.031 & 0.92 & 0.65 \\
\hline $6 \mathrm{~b}$ & 2.04 & 0.108 & 0.126 & 0.107 & 1.17 & 0.99 \\
\hline $7 \mathrm{a}$ & 2.04 & 0.147 & 0.173 & 0.154 & 1.18 & 1.05 \\
\hline $7 b$ & 3.78 & 0.199 & 0.209 & 0.186 & 1.05 & 0.93 \\
\hline $8 \mathrm{a}$ & 3.89 & 0.062 & 0.098 & 0.082 & 1.58 & 1.32 \\
\hline $8 b$ & 2.90 & 0.064 & 0.125 & 0.112 & 1.95 & 1.75 \\
\hline $9 a$ & 2.04 & 0.057 & 0.113 & 0.096 & 1.98 & 1.68 \\
\hline $9 \mathrm{~b}$ & 1.75 & 0.100 & 0.097 & 0.076 & 0.97 & 0.76 \\
\hline cl & 6.00 & 0.329 & 0.355 & 0.328 & 1.08 & 1.00 \\
\hline c2 & 6.04 & 0.274 & 0.283 & 0.258 & 1.03 & 0.94 \\
\hline c3 & 22.15 & 0.285 & 0.293 & 0.267 & 1.03 & 0.94 \\
\hline C4 & 2.01 & 0.091 & 0.116 & 0.097 & 1.27 & 1.07 \\
\hline c5 & 3.97 & 0.186 & 0.221 & 0.198 & 1.19 & 1.06 \\
\hline e6 & 2.57 & 0.124 & 0.150 & 0.127 & 1.21 & 1.02 \\
\hline 10 & 3.94 & 0.153 & 0.146 & 0.126 & 0.95 & 0.82 \\
\hline Ii & 2.66 & 0.100 & 0.082 & 0.066 & 0.82 & 0.66 \\
\hline 2 & 7.00 & 0.233 & 0.207 & 0.178 & 0.89 & 0.76 \\
\hline$\sqrt{3}$ & 16.83 & 0.272 & 0.194 & 0.165 & 0.71 & 0.61 \\
\hline \multirow{4}{*}{$\begin{array}{l}g 1 \\
g^{2}\end{array}$} & 3.00 & 0.108 & 0.105 & 0.083 & 0.97 & 0.77 \\
\hline & 6.00 & 0.128 & 0.118 & 0.094 & 0.92 & 0.73 \\
\hline & & \multirow{2}{*}{\multicolumn{3}{|c|}{$\begin{array}{l}\text { Mean } \\
\text { Std. Dev. } \\
\text { Coef. of Var. }\end{array}$}} & 1,13 & 0.97 \\
\hline & & & & & $\begin{array}{r}0.30 \\
26.37\end{array}$ & $\begin{array}{r}0.27 \\
28.09\end{array}$ \\
\hline
\end{tabular}

\begin{tabular}{|c|c|c|c|c|}
\hline \multicolumn{5}{|c|}{ Deflection Across the Opening } \\
\hline \multicolumn{3}{|c|}{ Deflection (in.) } & \multicolumn{2}{|c|}{$\begin{array}{c}\text { Calc. - Meas. } \\
\text { ratio } \\
\end{array}$} \\
\hline \multirow[b]{2}{*}{ meas. } & \multicolumn{2}{|c|}{ Calculated } & \multirow[b]{2}{*}{ v } & \multirow[b]{2}{*}{ NV } \\
\hline & $\mathrm{v}$ & NV & & \\
\hline$\overline{0.065}$ & $\overline{0.071}$ & $\overline{0.063}$ & 1.09 & 0.97 \\
\hline 0.060 & 0.065 & 0.057 & 1.08 & 0.95 \\
\hline 0.052 & 0.026 & 0.024 & 0.50 & 0.46 \\
\hline 0.052 & 0.059 & 0.052 & 1.13 & 1.00 \\
\hline 0.081 & 0.086 & 0.075 & 1.06 & 0.93 \\
\hline 0.047 & 0.054 & 0.047 & 1.15 & 1.00 \\
\hline 0.066 & 0.084 & 0.074 & 1.27 & 1.12 \\
\hline 0.061 & 0.089 & 0.080 & 1.46 & 1.31 \\
\hline 0.061 & 0.083 & 0.074 & 1.36 & 1.21 \\
\hline 0.033 & 0.045 & 0.039 & 1.36 & 1.18 \\
\hline 0.028 & 0.120 & 0.113 & 4.29 & 4.04 \\
\hline 0.055 & 0.113 & 0.104 & 2.05 & 1.89 \\
\hline 0.046 & 0.048 & 0.040 & 1.04 & 0.87 \\
\hline 0.051 & 0.072 & 0.064 & 1.41 & 1.25 \\
\hline 0.060 & 0.070 & 0.062 & 1.17 & 1.03 \\
\hline 0.028 & 0.037 & 0.034 & 1.32 & 1.21 \\
\hline 0.023 & 0.083 & 0.073 & 3.61 & 3.17 \\
\hline 0.059 & 0.084 & 0.075 & 1.42 & 1.27 \\
\hline 0.048 & 0.074 & 0.065 & 1.54 & 1.35 \\
\hline 0.031 & 0.054 & 0.048 & 1.74 & 1.55 \\
\hline 0.038 & 0.050 & 0.044 & 1.32 & 1.16 \\
\hline 0.047 & 0.054 & 0.047 & 1.15 & 1.00 \\
\hline \multirow[t]{3}{*}{0.017} & 0.022 & 0.018 & 1.29 & 1.06 \\
\hline & \multirow{2}{*}{\multicolumn{2}{|c|}{$\begin{array}{l}\text { Mean } \\
\text { Std. Dev. } \\
\text { Coef. of Var. }\end{array}$}} & 1.59 & 1.42 \\
\hline & & & $\begin{array}{r}0.88 \\
54.93\end{array}$ & $\begin{array}{r}0.82 \\
57.72\end{array}$ \\
\hline
\end{tabular}

Table A2. Measured and calculated deflections for Model 1 using $\mathrm{I}_{\text {eff }}$ at $60 \%$ of ultimate load

\begin{tabular}{|c|c|c|c|c|c|c|}
\hline \multirow[b]{4}{*}{ Test } & \multirow[b]{4}{*}{$\frac{M}{V d}$} & \multicolumn{5}{|c|}{ Deflection @ Point of Maximum Moment } \\
\hline & & \multicolumn{3}{|c|}{ Deflection (in.) } & \multicolumn{2}{|c|}{$\begin{array}{c}\text { Calc. - Meas. } \\
\text { ratio }\end{array}$} \\
\hline & & \multirow[b]{2}{*}{ meas. } & \multicolumn{2}{|c|}{ Calculated } & \multirow[b]{2}{*}{$\mathrm{V}$} & \multirow[b]{2}{*}{ NV } \\
\hline & & & $\mathrm{v}$ & NV & & \\
\hline 1 & 2.04 & $\overline{0.256}$ & $\overline{0.254}$ & $\overline{0.216}$ & 0.99 & $\overline{0.84}$ \\
\hline 2 & 3.78 & 0.305 & 0.268 & 0.230 & 0.88 & 0.75 \\
\hline 3 & 26.30 & 0.447 & 0.414 & 0.366 & 0.93 & 0.82 \\
\hline $5 a$ & 3.78 & 0.244 & 0.266 & 0.234 & 1.09 & 0.96 \\
\hline $5 b$ & 3.78 & 0.303 & 0.286 & 0.252 & 0.94 & 0.83 \\
\hline $6 a$ & 0.00 & 0.107 & 0.088 & 0.062 & 0.82 & 0.58 \\
\hline $6 \mathrm{~b}$ & 2.04 & 0.246 & 0.252 & 0.214 & 1.02 & 0.87 \\
\hline $7 a$ & 2.04 & 0.321 & 0.346 & 0.308 & 1.08 & 0.96 \\
\hline $7 \mathrm{~b}$ & 3.78 & 0.409 & 0.418 & 0.372 & 1.02 & 0.91 \\
\hline $8 \mathrm{a}$ & 3.89 & 0.159 & 0.196 & 0.164 & 1.23 & 1.03 \\
\hline $8 \mathrm{~b}$ & 2.90 & 0.146 & 0.250 & 0.224 & 1.71 & 1.53 \\
\hline $9 \mathrm{a}$ & 2.04 & 0.152 & 0.226 & 0.192 & 1.49 & 1.26 \\
\hline $9 b$ & 1.75 & 0.223 & 0,194 & 0.152 & 0.87 & 0.68 \\
\hline $\mathrm{cl}$ & 6.00 & 0.836 & 0.710 & 0.656 & 0.85 & 0.78 \\
\hline$c^{2}$ & 6.04 & 0.643 & 0.566 & 0.516 & 0.88 & 0.80 \\
\hline$c 3$ & 22.15 & 0.679 & 0.586 & 0.534 & 0,86 & 0.79 \\
\hline$c 4$ & 2.01 & 0.216 & 0.232 & 0.194 & 1.07 & 0.90 \\
\hline c5 & 3.97 & 0.403 & 0.442 & 0.396 & 1.10 & 0.98 \\
\hline c6 & 2.57 & 0.277 & 0.300 & 0.254 & 1.08 & 0.92 \\
\hline ro & 3.94 & 0.272 & 0.292 & 0.252 & 1.07 & 0.93 \\
\hline $\mathrm{rl}$ & 2.66 & 0.230 & 0.164 & 0.132 & 0.71 & 0.57 \\
\hline 2 & 7.00 & 0.453 & 0.414 & 0.356 & 0.91 & 0.79 \\
\hline$x^{3}$ & 16.83 & 0.585 & 0.388 & 0.330 & 0.66 & 0.56 \\
\hline \multirow{5}{*}{$\begin{array}{l}\mathrm{g} 1 \\
\mathrm{~g}^{2}\end{array}$} & 3.00 & 0.216 & 0.210 & 0.166 & 0.97 & 0.77 \\
\hline & 6.00 & 0.255 & 0.236 & 0.188 & 0.93 & 0.74 \\
\hline & & \multirow{3}{*}{\multicolumn{3}{|c|}{$\begin{array}{l}\text { Mean } \\
\text { Std. Dev. } \\
\text { Coef. of Var. }\end{array}$}} & 1.01 & 0.86 \\
\hline & & & & & 0.22 & 0.20 \\
\hline & & & & & 21.53 & 23.53 \\
\hline
\end{tabular}

\begin{tabular}{|c|c|c|c|c|}
\hline \multicolumn{5}{|c|}{ Deflection Across the Opening } \\
\hline \multicolumn{3}{|c|}{ Deflection (in ) } & \multicolumn{2}{|c|}{$\begin{array}{c}\text { Calc. - Meas. } \\
\text { ratio }\end{array}$} \\
\hline \multirow[b]{2}{*}{ meas. } & \multicolumn{2}{|c|}{ Calculated } & \multirow[b]{2}{*}{$\mathrm{v}$} & \multirow[b]{2}{*}{ NV } \\
\hline & $\mathrm{v}$ & NV & & \\
\hline$\overline{0.170}$ & $\overline{0.142}$ & $\overline{0.126}$ & 0.84 & 0.74 \\
\hline 0.161 & 0.130 & 0.114 & 0.81 & 0.71 \\
\hline 0.088 & 0.052 & 0.048 & 0.59 & 0.55 \\
\hline 0.127 & 0.118 & 0.104 & 0.93 & 0.82 \\
\hline 0.214 & 0.172 & 0.150 & 0.80 & 0.70 \\
\hline 0.149 & 0.108 & 0.094 & 0.72 & 0.63 \\
\hline 0.162 & 0.168 & 0.148 & 1.04 & 0.91 \\
\hline 0.150 & 0.178 & 0.160 & 1.19 & 1.07 \\
\hline 0.130 & 0.166 & 0.148 & 1.28 & 1.14 \\
\hline 0.090 & 0.090 & 0.078 & 1.00 & 0.87 \\
\hline 0.102 & 0.240 & 0.226 & 2.35 & 2.22 \\
\hline 0.174 & 0.226 & 0.208 & 1.30 & 1.20 \\
\hline 0.130 & 0.096 & 0.080 & 0.74 & 0.62 \\
\hline 0.034 & 0.144 & 0.128 & 4.24 & 3.76 \\
\hline 0.154 & 0.140 & 0.124 & 0.91 & 0.81 \\
\hline 0.073 & 0.074 & 0.068 & 1.01 & 0.93 \\
\hline 0.058 & 0.166 & 0.146 & 2.86 & 2.52 \\
\hline 0.139 & 0.168 & 0.150 & 1.21 & 1.08 \\
\hline 0.116 & 0.148 & 0.130 & 1.28 & 1.12 \\
\hline 0.062 & 0.108 & 0.096 & 1.74 & 1.55 \\
\hline 0.115 & 0.100 & 0.088 & 0.87 & 0.77 \\
\hline 0.096 & 0.108 & 0.094 & 1.13 & 0.98 \\
\hline \multirow[t]{3}{*}{0.033} & 0.044 & 0.036 & 1.33 & 1.09 \\
\hline & & 1.15 & 1.08 \\
\hline & \multicolumn{2}{|c|}{$\begin{array}{l}\text { Mean } \\
\text { Std. Dev. }\end{array}$} & $\begin{array}{r}0.55 \\
47.74\end{array}$ & $\begin{array}{r}0.51 \\
47.68\end{array}$ \\
\hline
\end{tabular}


Table A3. Measured and calculated deflections for Model 2 using $\mathrm{I}_{\text {eff }}$ at $30 \%$ of ultimate load

\begin{tabular}{|c|c|c|c|c|c|c|}
\hline \multirow[b]{4}{*}{ Test } & \multirow[b]{4}{*}{$\frac{M}{V d}$} & \multicolumn{5}{|c|}{ Deffection @ Point of Maximum Moment } \\
\hline & & \multicolumn{3}{|c|}{ Deflection (in.) } & \multicolumn{2}{|c|}{$\begin{array}{l}\text { Calc. - Meas. } \\
\text { ratio }\end{array}$} \\
\hline & & \multirow[b]{2}{*}{ meas. } & \multicolumn{2}{|c|}{ Calculated } & \multirow[b]{2}{*}{$\mathrm{v}$} & \multirow[b]{2}{*}{ NV } \\
\hline & & & v & NV & & \\
\hline 1 & 2.04 & $\overline{0.116}$ & $\overline{0.111}$ & $\overline{0.090}$ & $\overline{0.96}$ & 0.78 \\
\hline 2 & 3.78 & 0.137 & 0.116 & 0.095 & 0.85 & 0.69 \\
\hline 3 & 26.30 & 0.211 & 0.201 & 0.176 & 0.95 & 0.83 \\
\hline $5 a$ & 3.78 & 0.111 & 0.117 & 0.098 & 1.05 & 0.88 \\
\hline $5 b$ & 3.78 & 0.128 & 0.112 & 0.094 & 0.88 & 0.73 \\
\hline $6 \mathbf{a}$ & 0.00 & 0.048 & 0.030 & 0,015 & 0.63 & 0.31 \\
\hline $6 \mathrm{~b}$ & 2.04 & 0.108 & 0.097 & 0.074 & 0.90 & 0.69 \\
\hline $7 \mathrm{a}$ & 2.04 & 0.147 & 0.153 & 0.132 & 1.04 & 0.90 \\
\hline $7 \mathrm{~b}$ & 3.78 & 0.199 & 0.187 & 0.162 & 0.94 & 0.81 \\
\hline $8 \mathrm{a}$ & 3.89 & 0,062 & 0.083 & 0.065 & 1.34 & 1.05 \\
\hline $8 \mathrm{~b}$ & 2.90 & 0.064 & 0.063 & 0.047 & 0.98 & 0.73 \\
\hline $9 a$ & 2.04 & 0.057 & 0.066 & 0.046 & 1.16 & 0.81 \\
\hline $9 \mathrm{~b}$ & 1.75 & 0.100 & 0.085 & 0.061 & 0.85 & 0.61 \\
\hline c1 & 6.00 & 0.329 & 0.340 & 0.311 & 0.03 & 0.95 \\
\hline$c 2$ & 6.04 & 0.274 & 0.266 & 0.238 & 0.97 & 0.87 \\
\hline$c 3$ & 22.15 & 0.285 & 0.285 & 0.258 & 1.00 & 0.91 \\
\hline c4 & 2.01 & 0.091 & 0.093 & 0.070 & 1.02 & 0.77 \\
\hline$c 5$ & 3.97 & 0.186 & 0.201 & 0.175 & 1.08 & 0.94 \\
\hline$c 6$ & 2.57 & 0.124 & 0.131 & 0.106 & 1.06 & 0.85 \\
\hline 10 & 3.94 & 0.153 & 0.131 & 0.109 & 0.86 & 0.71 \\
\hline $\mathrm{rl}$ & 2.66 & 0.100 & 0.067 & 0.049 & 0.67 & 0.49 \\
\hline 2 & 7.00 & 0.233 & 0.194 & 0.163 & 0.83 & 0.70 \\
\hline 53 & 16.83 & 0.272 & 0.189 & 0.159 & 0.69 & 0.58 \\
\hline & 3.00 & 0.108 & 0.096 & 0.072 & 0.89 & 0.67 \\
\hline \multirow[t]{4}{*}{$\begin{array}{l}g 1 \\
82\end{array}$} & 6.00 & 0.128 & 0.113 & 0.087 & 0.88 & 0.68 \\
\hline & & \multirow{3}{*}{\multicolumn{3}{|c|}{$\begin{array}{l}\text { Mean } \\
\text { Std. Dev. } \\
\text { Coef. of Var }\end{array}$}} & 0.94 & 0.76 \\
\hline & & & & & 0.15 & 0.15 \\
\hline & & & & & 15.98 & 20.37 \\
\hline
\end{tabular}

\begin{tabular}{|c|c|c|c|c|}
\hline \multirow[b]{3}{*}{ meas. } & \multicolumn{2}{|c|}{ Deflection (in.) } & \multicolumn{2}{|c|}{$\begin{array}{c}\begin{array}{c}\text { Calc. - Meas. } \\
\text { ratio }\end{array} \\
\end{array}$} \\
\hline & \multicolumn{2}{|c|}{ Calculated } & \multirow[b]{2}{*}{ V } & \multirow[b]{2}{*}{ NV } \\
\hline & V & NV & & \\
\hline 0.065 & 0.041 & $\overline{0.030}$ & $\overline{0.63}$ & 0.46 \\
\hline 0.060 & 0.033 & 0.020 & 0.55 & 0.33 \\
\hline 0.052 & 0.017 & 0.013 & 0.33 & 0.25 \\
\hline 0.052 & 0.032 & 0.021 & 0.62 & 0.40 \\
\hline 0.081 & 0.032 & 0.020 & 0.40 & 0.25 \\
\hline 0.470 & 0.022 & 0.010 & 0.47 & 0.21 \\
\hline 0.066 & 0.044 & 0.029 & 0.67 & 0.44 \\
\hline 0.061 & 0.052 & 0.038 & 0.85 & 0.62 \\
\hline 0.061 & 0.047 & 0.034 & 0.77 & 0.56 \\
\hline 0.033 & 0.022 & 0.013 & 0.67 & 0.39 \\
\hline 0.028 & 0.029 & 0.017 & 1.04 & 0.61 \\
\hline 0.055 & 0.032 & 0.016 & 0.58 & 0.29 \\
\hline 0.046 & 0.025 & 0.012 & 0.54 & 0.26 \\
\hline 0.051 & 0.048 & 0.035 & 0.94 & 0.69 \\
\hline 0.060 & 0.041 & 0.028 & 0.68 & 0.47 \\
\hline 0.028 & 0.026 & 0.022 & 0.93 & 0.79 \\
\hline 0.023 & 0,042 & 0,026 & 1.83 & 1.13 \\
\hline 0.059 & 0.049 & 0.034 & 0.83 & 0.58 \\
\hline 0.048 & 0.041 & 0.026 & 0.85 & 0.54 \\
\hline 0.031 & 0.029 & 0.019 & 0.94 & 0.61 \\
\hline 0.038 & 0.024 & 0.014 & 0.63 & 0.37 \\
\hline 0.047 & 0.026 & 0.014 & 0.55 & 0.30 \\
\hline \multirow[t]{4}{*}{0.017} & 0.007 & 0.001 & 0.41 & 0.06 \\
\hline & \multirow{2}{*}{\multicolumn{2}{|c|}{ Mean }} & 0.74 & 0.46 \\
\hline & \multirow{2}{*}{\multicolumn{2}{|c|}{$\begin{array}{l}\text { Std. Dev } \\
\text { Coef. of }\end{array}$}} & 0.31 & 0.21 \\
\hline & & & 41.77 & 44.99 \\
\hline
\end{tabular}

Table A4. Measured and calculated deflections for Model 2 using $I_{\text {eff }}$ at $60 \%$ of ultimate load

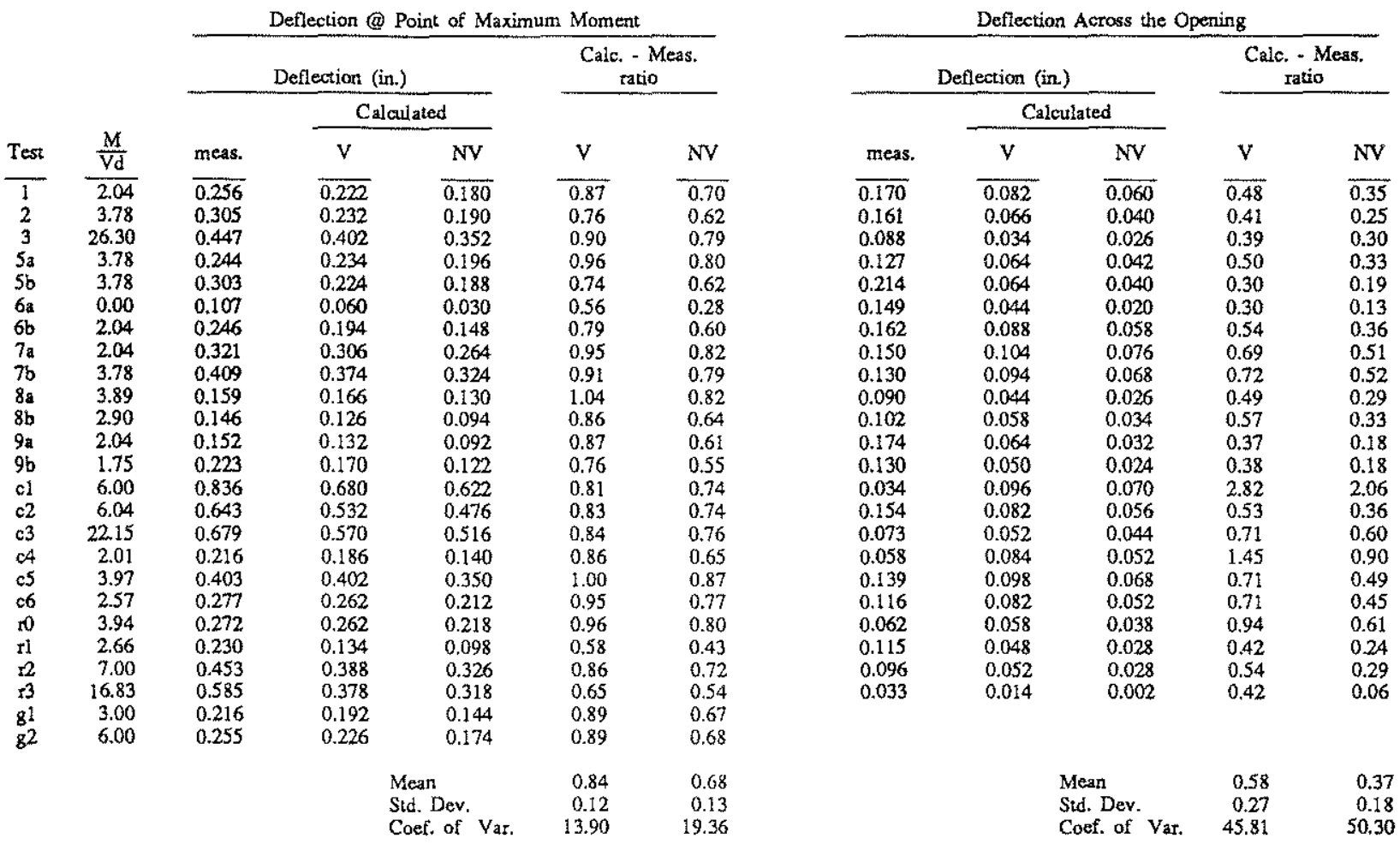


Table A5. Measured and calculated deflections for Model 3 using $\mathrm{I}_{\text {eff }}$ at $30 \%$ of ultimate load

\begin{tabular}{|c|c|c|c|c|c|c|c|c|c|c|c|}
\hline \multirow[b]{4}{*}{ Test } & \multirow[b]{4}{*}{$\frac{M}{V d}$} & \multicolumn{5}{|c|}{ Deflection @ Point of Maximum Moment } & \multicolumn{5}{|c|}{ Deflection Across the Operting } \\
\hline & & \multicolumn{3}{|c|}{ Deflection (in.) } & \multicolumn{2}{|c|}{$\begin{array}{l}\text { Calc. - Meas. } \\
\text { ratio }\end{array}$} & \multicolumn{3}{|c|}{ Deflection (in.) } & \multicolumn{2}{|c|}{$\begin{array}{c}\text { Calc - Meas. } \\
\text { ratio }\end{array}$} \\
\hline & & \multirow[b]{2}{*}{ meas. } & \multicolumn{2}{|c|}{ Calculated } & \multirow[b]{2}{*}{$\mathrm{V}$} & \multirow[b]{2}{*}{ NV } & \multirow[b]{2}{*}{ meas. } & \multicolumn{2}{|c|}{ Calculated } & \multirow[b]{2}{*}{$\mathrm{v}$} & \multirow[b]{2}{*}{ NV } \\
\hline & & & $\mathrm{v}$ & NV & & & & $\mathrm{v}$ & NV & & \\
\hline 1 & 2.04 & $\overline{0.116}$ & $\overline{0.114}$ & 0.095 & 0.98 & $\overline{0.82}$ & $\overline{0.065}$ & $\overline{0.048}$ & $\overline{0.038}$ & $\overline{0.74}$ & 0.58 \\
\hline 2 & 3.78 & 0.137 & 0.119 & 0.099 & 0.87 & 0.72 & 0.060 & 0.040 & 0.029 & 0.67 & 0.48 \\
\hline 3 & 26.30 & 0.211 & 0.202 & 0.177 & 0.96 & 0.84 & 0.052 & 0.016 & 0.013 & 0.31 & 0.25 \\
\hline $5 \mathbf{a}$ & 3.78 & 0.111 & 0.120 & 0.102 & 1.08 & 0.92 & 0.052 & 0.038 & 0.029 & 0.73 & 0.56 \\
\hline $5 b$ & 3.78 & 0.128 & 0.116 & 0.098 & 0.91 & 0.77 & 0.081 & 0.040 & 0.028 & 0.49 & 0.35 \\
\hline $6 a$ & 0.00 & 0.048 & 0.033 & 0.019 & 0.69 & 0.40 & 0.047 & 0.030 & 0.021 & 0.64 & 0.45 \\
\hline $6 b$ & 2.04 & 0.108 & 0.102 & 0.082 & 0.94 & 0.76 & 0.066 & 0.053 & 0.040 & 0.80 & 0.61 \\
\hline $7 \mathbf{a}$ & 2.04 & 0.147 & 0.157 & 0.137 & 1.07 & 0.93 & 0.061 & 0.060 & 0.049 & 0.98 & 0.80 \\
\hline 76 & 3.78 & 0.199 & 0.191 & 0.167 & 0.96 & 0.84 & 0.061 & 0.055 & 0.043 & 0.90 & 0.70 \\
\hline $8 \mathrm{a}$ & 3.89 & 0.062 & 0.085 & 0.069 & 1.37 & 1.11 & 0.033 & 0.026 & 0.018 & 0.79 & 0.55 \\
\hline $8 \mathrm{~b}$ & 2.90 & 0.064 & 0.073 & 0.059 & 1.14 & 0.92 & 0.028 & 0.046 & 0.035 & 1.64 & 1.25 \\
\hline $9 \mathrm{a}$ & 204 & 0.057 & 0.075 & 0.057 & 1.32 & 1.00 & 0.055 & 0.049 & 0.036 & 0.89 & 0.65 \\
\hline $9 b$ & 1.75 & 0.100 & 0.085 & 0.064 & 0.85 & 0.64 & 0.046 & 0.029 & 0.018 & 0.63 & 0.39 \\
\hline $\mathrm{cl}$ & 6.00 & 0.329 & 0.341 & 0.312 & 1.04 & 0.95 & 0.051 & 0.048 & 0.035 & 0.94 & 0.69 \\
\hline c2 & 6.04 & 0.274 & 0.268 & 0.242 & 0.98 & 0.88 & 0.060 & 0,047 & 0.036 & 0.78 & 0.60 \\
\hline c3 & 22.15 & 0.285 & 0.287 & 0.260 & 1.01 & 0.91 & 0.028 & 0.026 & 0.022 & 0.93 & 0.79 \\
\hline 04 & 2.01 & 0.091 & 0.098 & 0.077 & 1.08 & 0.85 & 0.023 & 0.052 & 0.038 & 2.26 & 1.65 \\
\hline es & 3.97 & 0.186 & 0.205 & 0.180 & 1.10 & 0.97 & 0.059 & 0.056 & 0.044 & 0.95 & 0.75 \\
\hline$c 6$ & 2.57 & 0.124 & 0.135 & 0.110 & 1.09 & 0.89 & 0.048 & 0.047 & 0.034 & 0.98 & 0.71 \\
\hline$x 0$ & 3.94 & 0.153 & 0.134 & 0.113 & 0.88 & 0.74 & 0.031 & 0.033 & 0.025 & 1.06 & 0.81 \\
\hline $\mathbf{n} 1$ & 2.66 & 0.100 & 0.069 & 0.053 & 0.69 & 0.53 & 0.038 & 0.030 & 0.020 & 0.79 & 0.53 \\
\hline$n$ & 7.00 & 0.233 & 0.200 & 0.170 & 0.86 & 0.73 & 0.047 & 0.031 & 0.020 & 0.66 & 0.43 \\
\hline $\mathrm{r}^{3}$ & 16.83 & 0.272 & 0.189 & 0.160 & 0.69 & 0.59 & 0.017 & 0.009 & 0.003 & 0.53 & 0.18 \\
\hline g1 & 3.00 & 0.108 & 0.097 & 0.075 & 0.90 & 0.69 & & & & & \\
\hline \multirow[t]{4}{*}{$8^{2}$} & 6.00 & 0.128 & 0.114 & 0.089 & 0.89 & 0.70 & & & & & \\
\hline & & \multirow{3}{*}{\multicolumn{3}{|c|}{$\begin{array}{l}\text { Mean } \\
\text { Std. Dev. } \\
\text { Coef. of Var. }\end{array}$}} & 0.97 & 0.80 & \multirow{3}{*}{\multicolumn{3}{|c|}{$\begin{array}{l}\text { Mean } \\
\text { Std. Dev. } \\
\text { Coef. of Yar. }\end{array}$}} & 0.91 & 0.68 \\
\hline & & & & & 0.16 & 0.16 & & & & 0.41 & 0.31 \\
\hline & & & & & 16.90 & 19.49 & & & & 44.30 & 45.81 \\
\hline
\end{tabular}

Table A6. Measured and calculated deflections for Model 3 using $I_{\text {eff }}$ at $60 \%$ of ultimate load

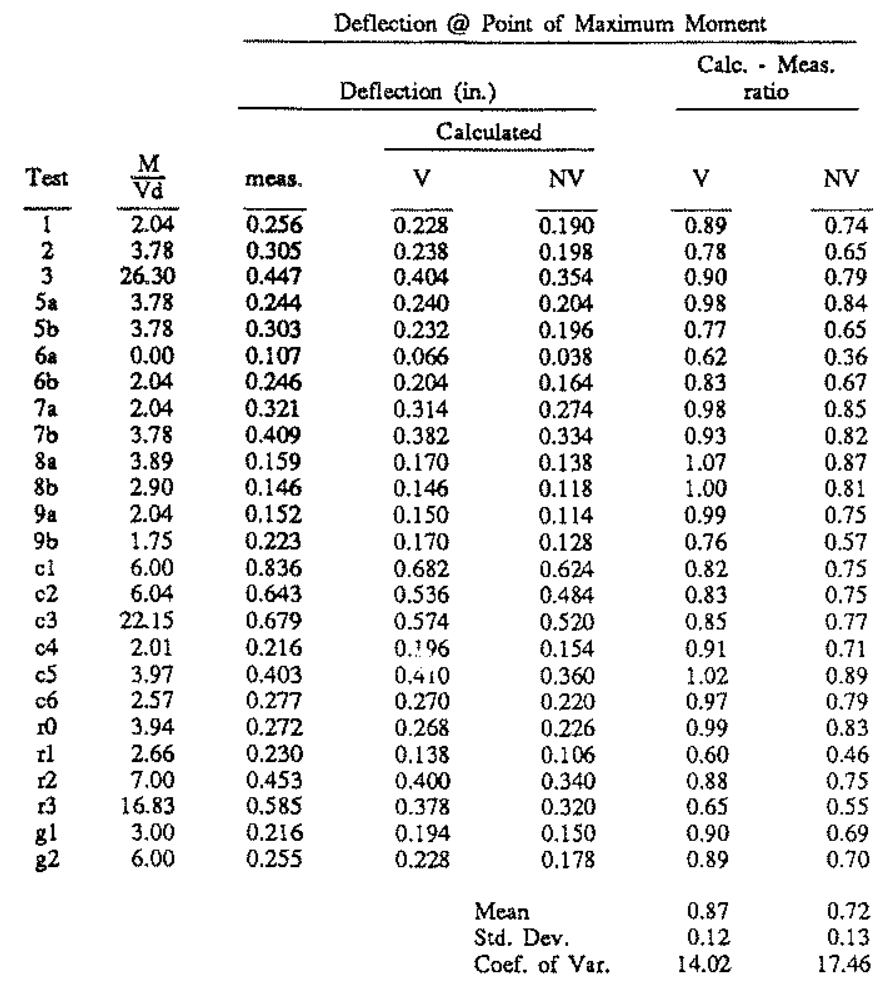

\begin{tabular}{|c|c|c|c|c|}
\hline \multicolumn{5}{|c|}{ Deflection Across the Opening } \\
\hline \multicolumn{3}{|c|}{ Deflection (in.) } & \multicolumn{2}{|c|}{$\begin{array}{c}\text { Calc. - Meas. } \\
\text { ratio }\end{array}$} \\
\hline \multirow[b]{2}{*}{ meas. } & \multicolumn{2}{|c|}{ Calculated } & \multirow[b]{2}{*}{$\mathrm{V}$} & \multirow[b]{2}{*}{ NV } \\
\hline & v & NV & & \\
\hline 0.170 & 0.096 & $\overline{0.076}$ & 0.56 & 0.45 \\
\hline & 0.080 & 0.058 & & 0.36 \\
\hline 0.088 & 0.032 & 0.026 & 0.36 & 0.30 \\
\hline 0.127 & 0.076 & 0.058 & 0.60 & 0.46 \\
\hline 0.214 & 0.080 & 0.056 & 0.37 & 0.26 \\
\hline 0.149 & 0.060 & 0.042 & 0.40 & 0.28 \\
\hline 0.162 & 0.106 & 0.080 & 0.65 & 0.49 \\
\hline 0.150 & 0.120 & 0.098 & 0.80 & 0.65 \\
\hline 0.130 & 0.110 & 0.086 & 0.85 & 0.66 \\
\hline 0.090 & 0.052 & 0.036 & 0.58 & 0.40 \\
\hline 0.102 & 0.092 & 0.070 & 0.90 & 0.69 \\
\hline 0.174 & 0.098 & 0.072 & 0.56 & 0.41 \\
\hline 0.130 & 0.058 & 0.036 & 0.45 & 0.28 \\
\hline 0.034 & 0.096 & 0.070 & 2.82 & 2.06 \\
\hline 0.154 & 0.094 & 0.072 & 0.61 & 0.47 \\
\hline 0.073 & 0.052 & 0.044 & 0.71 & 0.60 \\
\hline 0.058 & 0.104 & 0.076 & 1.79 & 1.31 \\
\hline 0.139 & 0.112 & 0.088 & 0.81 & 0.63 \\
\hline 0.116 & 0.094 & 0.068 & 0.81 & 0.59 \\
\hline 0.062 & 0.066 & 0.050 & 1.06 & 0.81 \\
\hline 0.115 & 0.060 & 0.040 & 0.52 & 0.35 \\
\hline & 0.062 & 0.040 & 0.65 & 0.42 \\
\hline \multirow[t]{3}{*}{0.033} & 0.018 & 0.006 & 0.55 & 0.18 \\
\hline & \multirow{2}{*}{\multicolumn{2}{|c|}{$\begin{array}{l}\text { Mean } \\
\text { Std. Dev. } \\
\text { Coef, of Var. }\end{array}$}} & 0.71 & \\
\hline & & & $\begin{array}{r}0.32 \\
44.89\end{array}$ & $\begin{array}{r}0.24 \\
46.59\end{array}$ \\
\hline
\end{tabular}


Table A7. Measured and calculated deflections for Model 1 using $I_{1 b}$ at $30 \%$ of ultimate load

\begin{tabular}{|c|c|c|c|c|c|c|}
\hline \multirow[b]{4}{*}{ Test } & \multirow[b]{4}{*}{$\frac{\mathrm{M}}{\mathrm{Vd}}$} & \multicolumn{5}{|c|}{ Deflection @ Point of Maximum Moment } \\
\hline & & \multicolumn{3}{|c|}{ Deflection (in.) } & \multicolumn{2}{|c|}{$\begin{array}{c}\text { Calc. - Meas. } \\
\text { ratio }\end{array}$} \\
\hline & & \multirow[b]{2}{*}{ meas. } & \multicolumn{2}{|c|}{ Calculated } & \multirow[b]{2}{*}{$\mathrm{V}$} & \multirow[b]{2}{*}{ NV } \\
\hline & & & V & NV & & \\
\hline 1 & 2.04 & $\overline{0.116}$ & $\overline{0.146}$ & $\overline{0.128}$ & 1.26 & 1.10 \\
\hline 2 & 3.78 & 0.137 & 0.152 & 0.133 & 1.11 & 0.97 \\
\hline 3 & 26.30 & 0.211 & 0.235 & 0.211 & 1.11 & 1.00 \\
\hline $5 a$ & 3.78 & 0.111 & 0.15 & 0.135 & 1.36 & 1.22 \\
\hline $5 b$ & 3.78 & 0.128 & 0.157 & 0.139 & 1.23 & 1.09 \\
\hline $6 a$ & 0.00 & 0.048 & 0.047 & 0.034 & 0.98 & 0.71 \\
\hline $6 \mathrm{~b}$ & 2.04 & 0.108 & 0.140 & 0.121 & 1.30 & 1.12 \\
\hline $7 \mathbf{a}$ & 2.04 & 0.147 & 0.188 & 0.169 & 1.28 & 1.15 \\
\hline $7 \mathrm{~b}$ & 3.78 & 0.199 & 0.231 & 0.209 & 1.16 & 1.05 \\
\hline $8 a$ & 3.89 & 0.062 & 0.115 & 0.099 & 1.85 & 1.60 \\
\hline $8 \mathrm{~b}$ & 2.90 & 0.064 & 0.134 & 0.121 & 2.09 & 1.89 \\
\hline $9 a$ & 2.04 & 0.057 & 0.119 & 0.103 & 2.09 & 1.81 \\
\hline $9 \mathrm{~b}$ & 1.75 & 0.100 & 0.105 & 0.085 & 1.05 & 0.85 \\
\hline ci & 6.00 & 0.329 & 0.401 & 0.375 & 1.22 & 1.14 \\
\hline$c 2$ & 6.04 & 0.274 & 0.317 & 0.292 & 1.16 & 1.07 \\
\hline c3 & 22.15 & 0.285 & 0.331 & 0.305 & 1.16 & 1.07 \\
\hline c4 4 & 2.01 & 0.091 & 0.123 & 0.104 & 1.35 & 1.14 \\
\hline$c 5$ & 3.97 & 0.186 & 0.247 & 0.224 & 1.33 & 1.20 \\
\hline c6 & 2.57 & 0.124 & 0.167 & 0.145 & 1.35 & 1.17 \\
\hline 50 & 3.94 & 0.153 & 0.175 & 0.155 & 1.14 & 1.01 \\
\hline $\mathrm{rl}$ & 2.66 & 0.100 & 0.093 & 0.077 & 0.93 & 0.77 \\
\hline 22 & 7.00 & 0.233 & 0.255 & 0.226 & 1.09 & 0.97 \\
\hline 53 & 16.83 & 0.272 & 0.217 & 0.188 & 0.80 & 0.69 \\
\hline & 3.00 & 0.108 & 0.118 & 0.097 & 1.09 & 0.90 \\
\hline \multirow[t]{4}{*}{$\mathrm{g} 2$} & 6.00 & 0.128 & 0.136 & 0.112 & 1.06 & 0.88 \\
\hline & & \multicolumn{3}{|c|}{ Mean } & 1.26 & 1.10 \\
\hline & & \multirow{2}{*}{\multicolumn{3}{|c|}{$\begin{array}{l}\text { Std. Dev. } \\
\text { Coef. of Var. }\end{array}$}} & 0.31 & 0.29 \\
\hline & & & & & 24.53 & 25.95 \\
\hline
\end{tabular}

\begin{tabular}{|c|c|c|c|c|}
\hline \multicolumn{5}{|c|}{ Deflection Across the Opening } \\
\hline \multicolumn{3}{|c|}{ Deflection (in.) } & \multicolumn{2}{|c|}{$\begin{array}{c}\text { Calc. - Meas. } \\
\text { ratio }\end{array}$} \\
\hline \multirow[b]{2}{*}{ meas. } & \multicolumn{2}{|c|}{ Calculated } & \multirow[b]{2}{*}{$\mathrm{V}$} & \multirow[b]{2}{*}{ NV } \\
\hline & $\mathrm{v}$ & NV & & \\
\hline$\overline{0.065}$ & 0.076 & $\overline{0.069}$ & 1.17 & 1.06 \\
\hline 0.060 & 0.068 & 0.060 & 1.13 & 1.00 \\
\hline 0.052 & 0.028 & 0.026 & 0.54 & 0.50 \\
\hline 0.052 & 0.062 & 0.055 & 1.19 & 1.06 \\
\hline 0.081 & 0.089 & 0.076 & 1.10 & 0.94 \\
\hline 0.047 & 0.055 & 0.048 & 1.17 & 1.02 \\
\hline 0.066 & 0.088 & 0.078 & 1.33 & 1.18 \\
\hline 0.061 & 0.093 & 0.084 & 1.52 & 1.38 \\
\hline 0.061 & 0.087 & 0.078 & 1.43 & 1.28 \\
\hline 0.033 & 0.048 & 0.042 & 1.45 & 1.27 \\
\hline 0.028 & 0.124 & 0.116 & 4.43 & 4.14 \\
\hline 0,055 & 0.115 & 0.106 & 2.09 & 1.93 \\
\hline 0.046 & 0.049 & 0.042 & 1.07 & 0.91 \\
\hline 0.051 & 0.077 & 0.069 & 1.51 & 1.35 \\
\hline 0.060 & 0.073 & 0.065 & 1.22 & 1.08 \\
\hline 0.028 & 0.040 & 0.037 & 1.43 & 1,32 \\
\hline 0.023 & 0.086 & 0.075 & 3.74 & 3.26 \\
\hline 0.059 & 0.088 & 0.079 & 1.49 & 1.34 \\
\hline 0.048 & 0.078 & 0.068 & 1.63 & 1.42 \\
\hline 0.031 & 0.053 & 0.053 & 1.71 & 1.71 \\
\hline 0.038 & 0,046 & 0.046 & 1.21 & 1.21 \\
\hline 0.047 & 0.051 & 0.051 & 1.09 & 1.09 \\
\hline \multirow[t]{4}{*}{0.017} & 0.019 & 0.019 & 1.12 & 1.12 \\
\hline & & 1.64 & 1.49 \\
\hline & \multirow{2}{*}{\multicolumn{2}{|c|}{ Std. Dev. }} & 0.91 & 0.83 \\
\hline & & & 55.27 & 55.99 \\
\hline
\end{tabular}

Table A8. Measured and calculated deflections for Model 1 using $I_{b b}$ at $60 \%$ of ultimate load

\begin{tabular}{|c|c|c|c|c|c|c|}
\hline \multirow[b]{4}{*}{ Test } & \multirow[b]{4}{*}{$\frac{M}{V d}$} & \multicolumn{5}{|c|}{ Deflection@Point of Maximum Moment } \\
\hline & & \multicolumn{3}{|c|}{ Deflection (in.) } & \multicolumn{2}{|c|}{$\begin{array}{c}\text { Calc. - Meas. } \\
\text { ratio }\end{array}$} \\
\hline & & \multirow[b]{2}{*}{ meas. } & \multicolumn{2}{|c|}{ Calculated } & \multirow[b]{2}{*}{ v } & \multirow[b]{2}{*}{ NV } \\
\hline & & & v & NV & & \\
\hline 1 & 2.04 & 0.256 & $\overline{0.292}$ & $\overline{0.256}$ & 1.14 & 1.00 \\
\hline 2 & 3.78 & 0.305 & 0.304 & 0.266 & 1.00 & 0.87 \\
\hline 3 & 26.30 & 0.447 & 0.470 & 0.422 & 1.05 & 0.94 \\
\hline $5 a$ & 3.78 & 0.244 & 0.302 & 0.270 & 1.24 & 1.11 \\
\hline $5 b$ & 3.78 & 0.303 & 0.314 & 0.278 & 1.04 & 0.92 \\
\hline $6 a$ & 0.00 & 0.107 & 0.094 & 0.068 & 0.88 & 0.64 \\
\hline $6 b$ & 2.04 & 0.246 & 0.280 & 0.242 & 1.14 & 0.98 \\
\hline $7 a$ & 2.04 & 0.321 & 0.376 & 0.338 & 1.17 & 1.05 \\
\hline $7 \mathrm{~b}$ & 3.78 & 0.409 & 0.462 & 0.418 & 1.13 & 1.02 \\
\hline $8 a$ & 3.89 & 0.159 & 0.230 & 0.198 & 1.45 & 1.25 \\
\hline $8 b$ & 2.90 & 0.146 & 0.268 & 0.242 & 1.84 & 1.66 \\
\hline $9 a$ & 2.04 & 0.152 & 0.238 & 0.206 & 1.57 & 1.36 \\
\hline $9 \mathrm{~b}$ & 1.75 & 0.223 & 0.210 & 0.170 & 0.94 & 0.76 \\
\hline $\mathrm{cl}$ & 6.00 & 0.836 & 0.802 & 0.750 & 0.96 & 0.90 \\
\hline $\mathrm{c} 2$ & 6.04 & 0.643 & 0.634 & 0.584 & 0.99 & 0.91 \\
\hline$c 3$ & 22.15 & 0.679 & 0.662 & 0.610 & 0.97 & 0.90 \\
\hline$c 4$ & 2.01 & 0.216 & 0.246 & 0.208 & 1.14 & 0.96 \\
\hline$c 5$ & 3.97 & 0.403 & 0.494 & 0.448 & 1.23 & 1.11 \\
\hline$c 6$ & 2.57 & 0.277 & 0.334 & 0.290 & 1.21 & 1.05 \\
\hline 10 & 3.94 & 0.272 & 0.350 & 0.310 & 1.29 & 1.14 \\
\hline $\mathrm{r} 1$ & 2.66 & 0.230 & 0.186 & 0.154 & 0.81 & 0.67 \\
\hline 12 & 7,00 & 0.453 & 0.510 & 0.452 & 1.13 & 1.00 \\
\hline$x^{2}$ & 16.83 & 0.585 & 0.434 & 0.376 & 0.74 & 0.64 \\
\hline gl & 3.00 & 0.216 & 0.236 & 0.194 & 1.09 & 0.90 \\
\hline \multirow[t]{4}{*}{$g^{2}$} & 6.00 & 0.255 & 0.272 & 0.224 & 1.07 & 0.88 \\
\hline & & & 1.13 & 0.98 \\
\hline & & \multirow{2}{*}{\multicolumn{3}{|c|}{$\begin{array}{l}\text { Stc. Dev. } \\
\text { Coef. of Yar. }\end{array}$}} & 0.23 & 0.22 \\
\hline & & & & & 20.27 & 21.98 \\
\hline
\end{tabular}

\begin{tabular}{|c|c|c|c|c|}
\hline \multicolumn{5}{|c|}{ Deflection Across the Opening } \\
\hline \multicolumn{3}{|c|}{ Deflection (in.) } & \multicolumn{2}{|c|}{$\begin{array}{c}\text { Calc. Meas. } \\
\text { ratio }\end{array}$} \\
\hline \multirow[b]{2}{*}{ meas. } & \multicolumn{2}{|c|}{ Calculated } & \multirow[b]{2}{*}{$\mathrm{v}$} & \multirow[b]{2}{*}{$\mathrm{NV}$} \\
\hline & $\mathrm{v}$ & NV & & \\
\hline 0.170 & 0.152 & $\overline{0.138}$ & 0.89 & 0.81 \\
\hline 0.161 & 0.136 & 0.120 & 0.84 & 0.75 \\
\hline 0.088 & 0.056 & 0.052 & 0.64 & 0.59 \\
\hline 0.127 & 0.124 & 0.110 & 0.98 & 0.87 \\
\hline 0.214 & 0.178 & 0.152 & 0.83 & 0.71 \\
\hline 0.149 & 0.110 & 0.096 & 0.74 & 0.64 \\
\hline 0.162 & 0.176 & 0.156 & 1.09 & 0.96 \\
\hline 0.150 & 0.186 & 0.168 & 1.24 & 1.12 \\
\hline 0.130 & 0.174 & 0.156 & 1.34 & 1.20 \\
\hline 0.090 & 0.096 & 0.084 & 1.07 & 0.93 \\
\hline 0.102 & 0.248 & 0.232 & 2.43 & 2.27 \\
\hline 0.174 & 0.230 & 0.212 & 1.32 & 1.22 \\
\hline 0.130 & 0.098 & 0.084 & 0.75 & 0.65 \\
\hline 0.034 & 0.154 & 0.138 & 4.53 & 4.06 \\
\hline 0.154 & 0.146 & 0.130 & 0.95 & 0.84 \\
\hline 0.073 & 0.080 & 0.074 & 1.10 & 1.01 \\
\hline 0.058 & 0.172 & 0.150 & 2.97 & 2.59 \\
\hline 0.139 & 0.176 & 0.158 & 1.27 & 1.14 \\
\hline 0.116 & 0.156 & 0.136 & 1.34 & 1.17 \\
\hline 0.062 & 0.106 & 0.106 & 1.71 & 1.71 \\
\hline 0.115 & 0.092 & 0.092 & 0.80 & 0.80 \\
\hline 0.096 & 0.102 & 0.102 & 1.06 & 1.06 \\
\hline \multirow[t]{4}{*}{0.033} & 0.038 & 0.038 & 1.15 & 1.15 \\
\hline & \multirow{2}{*}{\multicolumn{2}{|c|}{$\begin{array}{l}\text { Mean } \\
\text { Std. Dev. }\end{array}$}} & 1.24 & 1.13 \\
\hline & & & 0.58 & 0.53 \\
\hline & \multicolumn{2}{|c|}{ Coef. of Var. } & 46.55 & 46.76 \\
\hline
\end{tabular}


Table A9. Measured and calculated deflections for Model 2 using $\mathrm{I}_{\mathrm{b}}$ at $30 \%$ of ultimate load

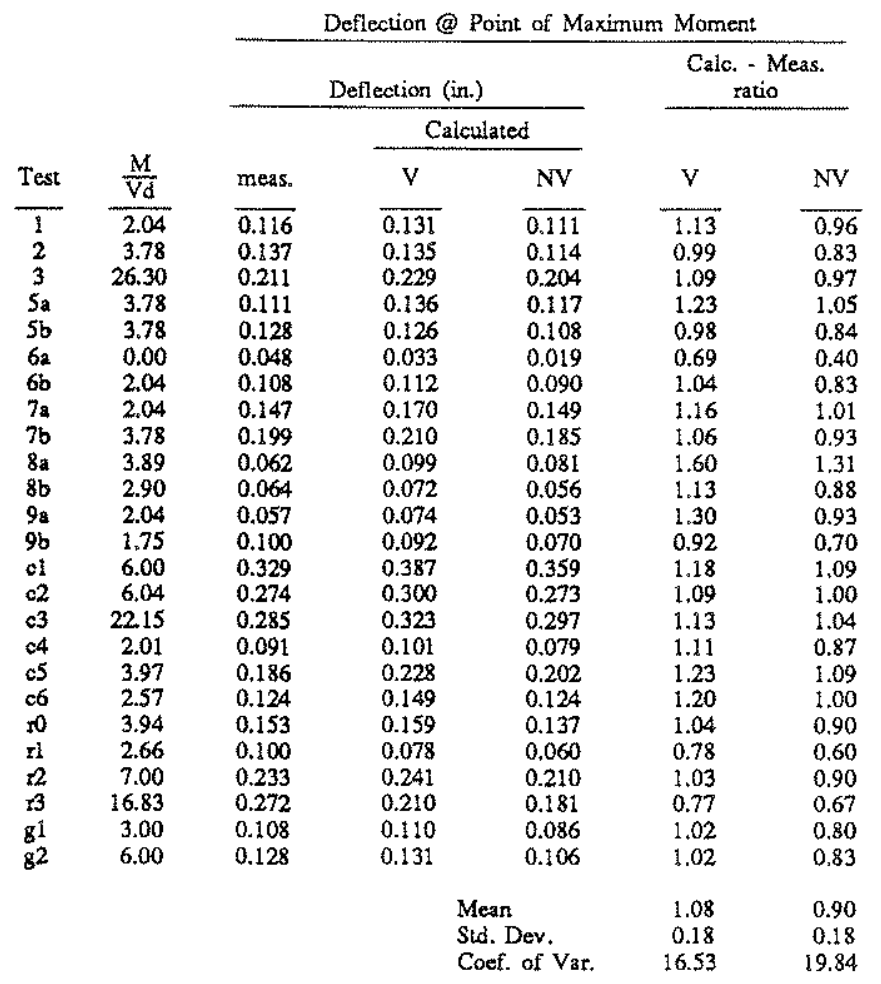

\begin{tabular}{|c|c|c|c|c|}
\hline \multicolumn{3}{|c|}{ Deflection (in.) } & \multicolumn{2}{|c|}{$\begin{array}{c}\text { Caic. - Meas. } \\
\text { ratio }\end{array}$} \\
\hline \multirow[b]{2}{*}{ meas. } & \multicolumn{2}{|c|}{ Calculated } & \multirow[b]{2}{*}{ V } & \multirow[b]{2}{*}{ NV } \\
\hline & $\mathrm{v}$ & NV & & \\
\hline$\overline{0.065}$ & $\overline{0.048}$ & $\overline{0.037}$ & $\overline{0.74}$ & 0.57 \\
\hline 0.060 & 0.037 & 0.025 & 0.62 & 0.42 \\
\hline 0.052 & 0.019 & 0.015 & 0.37 & 0.29 \\
\hline 0.052 & 0.036 & 0.025 & 0.69 & 0.48 \\
\hline 0.081 & 0.035 & 0.023 & 0.43 & 0.28 \\
\hline 0.047 & 0.024 & 0.013 & 0.51 & 0.28 \\
\hline 0.066 & 0.050 & 0.035 & 0.76 & 0.53 \\
\hline 0.061 & 0.058 & 0.045 & 0.95 & 0.74 \\
\hline 0.061 & 0.053 & 0.040 & 0.87 & 0.66 \\
\hline 0.033 & 0.025 & 0.016 & 0.76 & 0.48 \\
\hline 0.028 & 0.033 & 0.021 & 1.18 & 0.75 \\
\hline 0.055 & 0.035 & 0.019 & 0.64 & 0.35 \\
\hline 0.046 & 0.027 & 0.014 & 0.59 & 0.30 \\
\hline 0.051 & 0.053 & 0.041 & 1.04 & 0.80 \\
\hline 0.060 & 0.045 & 0.036 & 0.75 & 0.60 \\
\hline 0.028 & 0.029 & 0.025 & 1.04 & 0.89 \\
\hline 0.023 & 0.046 & 0.031 & 2.00 & 1.35 \\
\hline 0.059 & 0.054 & 0.041 & 0.92 & 0.69 \\
\hline 0.048 & 0.046 & 0.031 & 0.96 & 0.65 \\
\hline 0.031 & 0.034 & 0.024 & 1.10 & 0.77 \\
\hline 0.038 & 0.027 & 0.017 & 0.71 & 0.45 \\
\hline 0.047 & 0.030 & 0.018 & 0.64 & 0.38 \\
\hline \multirow[t]{4}{*}{0.017} & 0.008 & 0.002 & 0.47 & 0.12 \\
\hline & \multirow{3}{*}{\multicolumn{2}{|c|}{$\begin{array}{l}\text { Meas } \\
\text { Std. Dev. } \\
\text { Coef. of Var。 }\end{array}$}} & 0.83 & 0.65 \\
\hline & & & 0.34 & 0.30 \\
\hline & & & 41.02 & 45.46 \\
\hline
\end{tabular}

Table A10. Measured and calculated deflections for Model 2 using $I_{1 b}$ at $60 \%$ of ultimate load

\begin{tabular}{|c|c|c|c|c|c|c|}
\hline \multirow[b]{4}{*}{ Test } & \multirow[b]{4}{*}{$\frac{\mathrm{M}}{\mathrm{Vd}}$} & \multicolumn{5}{|c|}{ Deflection @ Point of Maximum Moment } \\
\hline & & \multicolumn{3}{|c|}{ Deflection (in.) } & \multicolumn{2}{|c|}{$\begin{array}{c}\text { Calc. = Meas. } \\
\text { ratio }\end{array}$} \\
\hline & & \multirow[b]{2}{*}{ meas. } & \multicolumn{2}{|c|}{ Caiculated } & \multirow[b]{2}{*}{$\mathrm{v}$} & \multirow[b]{2}{*}{ NV } \\
\hline & & & $\mathrm{v}$ & NV & & \\
\hline 1 & $\overline{2.04}$ & $\overline{0.256}$ & $\overline{0.262}$ & $\overline{0.222}$ & 1.02 & 0.87 \\
\hline 2 & 3.78 & 0.305 & 0.270 & 0.228 & 0.89 & 0.75 \\
\hline 3 & 26.30 & 0.447 & 0.458 & 0.408 & 1.02 & 0.91 \\
\hline $5 a$ & 3.78 & 0.244 & 0.272 & 0.234 & 1.11 & 0.96 \\
\hline $5 b$ & 3.78 & 0.303 & 0.252 & 0.216 & 0.83 & 0.71 \\
\hline $6 \mathrm{a}$ & 0.00 & 0.107 & 0.066 & 0.038 & 0.62 & 0.36 \\
\hline $6 \mathrm{~b}$ & 2.04 & 0.246 & 0.224 & 0.180 & 0.91 & 0.73 \\
\hline $7 a$ & 2.04 & 0.321 & 0.340 & 0.298 & 1.06 & 0.93 \\
\hline $7 b$ & 3.78 & 0.409 & 0.420 & 0.370 & 1.03 & 0.90 \\
\hline $8 a$ & 3.89 & 0.159 & 0.198 & 0.162 & 1.25 & 1.02 \\
\hline $8 \mathrm{~b}$ & 2.90 & 0.146 & 0.144 & 0.112 & 0.99 & 0.77 \\
\hline $9 a$ & 2.04 & 0.152 & 0.148 & 0.106 & 0.97 & 0.70 \\
\hline $9 \mathrm{~b}$ & 1.75 & 0.223 & 0.184 & 0.140 & 0.83 & 0.63 \\
\hline cl & 6.00 & 0.836 & 0.774 & 0.718 & 0.93 & 0.86 \\
\hline$c 2$ & 6.04 & 0.643 & 0.600 & 0.546 & 0.93 & 0.85 \\
\hline$c 3$ & 22.15 & 0.679 & 0.646 & 0.594 & 0.95 & 0.87 \\
\hline $\mathrm{c} 4$ & 2.01 & 0.216 & 0.202 & 0.158 & 0.94 & 0.73 \\
\hline c5 & 3.97 & 0.403 & 0.456 & 0.404 & 1.13 & 1.00 \\
\hline$c 6$ & 2.57 & 0.277 & 0.298 & 0.248 & 1.08 & 0.90 \\
\hline 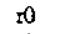 & 3.94 & 0.272 & 0.318 & 0.274 & 1.17 & 1.01 \\
\hline th & 2.66 & 0.230 & 0.156 & 0.120 & 0.68 & 0.52 \\
\hline 2 & 7.00 & 0.453 & 0.482 & 0.420 & 1.06 & 0.93 \\
\hline$x^{3}$ & 16.83 & 0.585 & 0.420 & 0.362 & 0.72 & 0.62 \\
\hline $\mathrm{g} !$ & 3.00 & 0.216 & 0.220 & 0.172 & 1.02 & 0.80 \\
\hline \multirow[t]{4}{*}{$\mathrm{g} 2$} & 6.00 & 0.255 & 0.262 & 0.212 & 1.03 & 0.83 \\
\hline & & \multicolumn{3}{|c|}{ Mean } & 0.97 & 0.81 \\
\hline & & \multirow{2}{*}{\multicolumn{3}{|c|}{$\begin{array}{l}\text { Std. Dev. } \\
\text { Coef. of Var. }\end{array}$}} & 0.15 & 0.16 \\
\hline & & & & & 15.13 & 19.35 \\
\hline
\end{tabular}

\begin{tabular}{|c|c|c|c|c|}
\hline \multicolumn{5}{|c|}{ Deflection Across the Opening } \\
\hline \multicolumn{3}{|c|}{ Deflection (in) } & \multicolumn{2}{|c|}{$\begin{array}{c}\text { Calc. Meas. } \\
\text { ratio }\end{array}$} \\
\hline \multirow[b]{2}{*}{ meas. } & \multicolumn{2}{|c|}{ Calculated } & \multirow[b]{2}{*}{$\mathrm{v}$} & \multirow[b]{2}{*}{ NV } \\
\hline & $\mathrm{v}$ & NV & & \\
\hline$\overline{0.170}$ & 0.096 & $\overline{0.074}$ & $\overline{0.56}$ & $\overline{0.44}$ \\
\hline $0.16 !$ & 0,074 & 0.050 & 0.46 & 0.31 \\
\hline 0.088 & 0.038 & 0.030 & 0.43 & 0.34 \\
\hline 0.127 & 0.072 & 0.050 & 0.57 & 0.39 \\
\hline 0.214 & 0.070 & 0.046 & 0.33 & 0.21 \\
\hline 0.149 & 0.048 & 0.026 & 0.32 & 0.17 \\
\hline 0.162 & 0.100 & 0.070 & 0.62 & 0.43 \\
\hline 0.150 & 0.116 & 0.090 & 0.77 & 0.60 \\
\hline 0.130 & 0.106 & 0.080 & 0.82 & 0.62 \\
\hline 0.090 & 0.050 & 0.032 & 0.56 & 0.36 \\
\hline 0.102 & 0.066 & 0.042 & 0.65 & 0.41 \\
\hline 0.174 & 0.070 & 0.038 & 0.40 & 0.22 \\
\hline 0.130 & 0.054 & 0.028 & 0.42 & 0.22 \\
\hline 0.034 & 0.106 & 0.082 & 3.12 & 2.41 \\
\hline 0.154 & 0.090 & 0.072 & 0.58 & 0.47 \\
\hline 0.073 & 0.058 & 0.050 & 0.79 & 0.68 \\
\hline 0.058 & 0.092 & 0.062 & 1.59 & 1.07 \\
\hline 0.139 & 0.108 & 0.082 & 0.78 & 0.59 \\
\hline 0.116 & 0.092 & 0.062 & 0.79 & 0.53 \\
\hline 0.062 & 0.068 & 0.048 & 1.10 & 0.77 \\
\hline 0.115 & 0.054 & 0.034 & 0.47 & 0.30 \\
\hline 0.096 & 0.060 & 0.036 & 0.63 & 0.38 \\
\hline \multirow[t]{3}{*}{0.033} & 0.016 & 0.004 & 0.48 & 0.12 \\
\hline & & 0.56 & 0.45 \\
\hline & \multicolumn{2}{|c|}{ Std. Dev. } & $\begin{array}{r}0.25 \\
44.16\end{array}$ & $\begin{array}{r}0.22 \\
49.12\end{array}$ \\
\hline
\end{tabular}


Table A11. Measured and calculated deflections for Model 3 using $I_{\mathrm{b}}$ at $30 \%$ of ultimate load

\begin{tabular}{|c|c|c|c|c|c|c|}
\hline \multirow[b]{4}{*}{ Test } & \multirow[b]{4}{*}{$\frac{\mathrm{M}}{\mathrm{Vd}}$} & \multicolumn{5}{|c|}{ Deflection@ Point of Maximum Moment } \\
\hline & & \multicolumn{3}{|c|}{ Deflection (in.) } & \multicolumn{2}{|c|}{$\begin{array}{l}\text { Calc. - Meas. } \\
\text { ratio }\end{array}$} \\
\hline & & \multirow[b]{2}{*}{ meas. } & \multicolumn{2}{|c|}{ Calculated } & \multirow[b]{2}{*}{$\mathrm{V}$} & \multirow[b]{2}{*}{ NV } \\
\hline & & & $\mathrm{V}$ & NV & & \\
\hline 1 & 2.04 & 0.116 & $\overline{0.134}$ & 0.115 & 1.16 & 0.99 \\
\hline 2 & 3.78 & 0.137 & 0.138 & 0.118 & 1.01 & 0.86 \\
\hline 3 & 26.30 & 0.211 & 0.230 & 0.205 & 1.09 & 0.97 \\
\hline $5 \mathbf{5}$ & 3.78 & 0.111 & 0.143 & 0.113 & 1.29 & 1.02 \\
\hline $5 b$ & 3.78 & 0.128 & 0.130 & 0.112 & 1.02 & 0.88 \\
\hline $6 \mathrm{a}$ & 0.00 & 0.048 & 0.036 & 0.023 & 0.75 & 0.48 \\
\hline $6 \mathrm{~b}$ & 2.04 & 0.108 & 0.117 & 0.097 & 1.08 & 0.90 \\
\hline $7 \mathrm{a}$ & 2.04 & 0.147 & 0.173 & 0.154 & 1.18 & 1.05 \\
\hline $7 \mathrm{~b}$ & 3.78 & 0.199 & 0.215 & 0.190 & 1.08 & 0.95 \\
\hline $8 \Omega$ & 3.89 & 0.062 & 0.102 & 0.085 & 1.65 & 1.37 \\
\hline 86 & 2.90 & 0.064 & 0.083 & 0.068 & 1.30 & 1.06 \\
\hline $9 \mathrm{a}$ & 2.04 & 0.057 & 0.082 & 0.065 & 1.44 & 1.14 \\
\hline $9 b$ & 1.75 & 0.100 & 0.094 & 0.073 & 0.94 & 0.73 \\
\hline \&1 & 6.00 & 0.329 & 0.390 & 0.362 & 1.19 & 1.10 \\
\hline$c 2$ & 6.04 & 0.274 & 0.301 & 0.277 & 1,10 & 1.01 \\
\hline c3 & 22.15 & 0.285 & 0.325 & 0.298 & 1.14 & 1.05 \\
\hline 04 & 2.01 & 0.091 & 0.106 & 0.085 & 1.16 & 0.93 \\
\hline c5 & 3.97 & 0.186 & 0.232 & 0.207 & 1.25 & 1.11 \\
\hline c6 & 2.57 & 0.124 & 0.153 & 0.128 & 1.23 & 1.03 \\
\hline 10 & 3.94 & 0.153 & 0.162 & 0.142 & 1.06 & 0.93 \\
\hline 11 & 2.66 & 0.100 & 0.080 & 0.064 & 0.80 & 0.64 \\
\hline 12 & 7.00 & 0.233 & 0.248 & 0.219 & 1.06 & 0.94 \\
\hline 53 & 16.83 & 0.272 & 0.211 & 0.183 & 0.78 & 0.67 \\
\hline gl & 3.00 & 0.108 & 0.111 & 0.089 & 1.03 & 0.82 \\
\hline \multirow[t]{4}{*}{$\mathrm{g} 2$} & 6.00 & 0.128 & 0.132 & 0.107 & 1.03 & 0.84 \\
\hline & & \multicolumn{3}{|c|}{ Mean } & 1.11 & 0.94 \\
\hline & & \multirow{2}{*}{\multicolumn{3}{|c|}{$\begin{array}{l}\text { Std. Dev. } \\
\text { Coef. of Var. }\end{array}$}} & 0.19 & 0.18 \\
\hline & & & & & 17.22 & 19.01 \\
\hline
\end{tabular}

\begin{tabular}{|c|c|c|c|c|}
\hline \multicolumn{5}{|c|}{ Deflection Across the Opering } \\
\hline \multicolumn{3}{|c|}{ Deflection (in.) } & \multicolumn{2}{|c|}{$\begin{array}{c}\text { Calc. - Meas. } \\
\text { ratio } \\
\end{array}$} \\
\hline \multirow[b]{2}{*}{ meas. } & \multicolumn{2}{|c|}{ Calculated } & \multirow[b]{2}{*}{$\mathrm{V}$} & \multirow[b]{2}{*}{ NV } \\
\hline & $\mathrm{V}$ & NV & & \\
\hline 0.065 & 0.055 & $\overline{0.045}$ & 0.85 & 0.69 \\
\hline 0.060 & 0.043 & 0.033 & 0.72 & 0.55 \\
\hline 0.052 & 0.017 & 0.014 & 0.33 & 0.27 \\
\hline 0.052 & 0.040 & 0.027 & 0.77 & 0.52 \\
\hline 0.081 & 0.044 & 0.032 & 0.54 & 0.40 \\
\hline 0.047 & 0.033 & 0.023 & 0.70 & 0.49 \\
\hline 0.066 & 0.059 & 0.046 & 0.89 & 0.70 \\
\hline 0.061 & 0.066 & 0.055 & 1.08 & 0.90 \\
\hline 0.061 & 0.060 & 0.049 & 0.98 & 0.80 \\
\hline 0.033 & 0.029 & 0.021 & 0.88 & 0.64 \\
\hline 0.028 & 0.049 & 0.039 & 1.75 & 1.39 \\
\hline 0.055 & 0.052 & 0.039 & 0.95 & 0.71 \\
\hline 0.046 & 0.031 & 0.020 & 0.67 & 0.43 \\
\hline 0.051 & 0.057 & 0.046 & 1.12 & 0.90 \\
\hline 0.060 & 0.048 & 0.039 & 0.80 & 0.65 \\
\hline 0.028 & 0,029 & 0.025 & 1.04 & 0.89 \\
\hline 0.023 & 0.056 & 0.043 & 2.43 & 1.87 \\
\hline 0.059 & 0.062 & 0.050 & 1.05 & 0.85 \\
\hline 0.048 & 0.052 & 0.040 & 1.08 & 0.83 \\
\hline 0.031 & 0.038 & 0.029 & 1.23 & 0.94 \\
\hline 0.038 & 0.032 & 0.023 & 0.84 & $0.6 i$ \\
\hline 0.047 & 0.034 & 0.024 & 0.72 & 0.51 \\
\hline \multirow[t]{4}{*}{0.017} & 0.008 & 0.003 & 0.47 & 0.18 \\
\hline & \multirow{3}{*}{\multicolumn{2}{|c|}{$\begin{array}{l}\text { Mean } \\
\text { Stod. Dev. } \\
\text { Coef. of Var. }\end{array}$}} & 1.00 & 0.76 \\
\hline & & & 0.44 & 0.35 \\
\hline & & & 43.71 & 46.20 \\
\hline
\end{tabular}

Table A12. Measured and calculated deflections for Model 3 using $I_{1 b}$ at $60 \%$ of ultimate load

\begin{tabular}{|c|c|c|c|c|c|c|}
\hline \multirow[b]{4}{*}{ Test } & \multirow[b]{4}{*}{$\frac{M}{V d}$} & \multicolumn{5}{|c|}{ Deflection @ Point of Mrximum Moment } \\
\hline & & \multicolumn{3}{|c|}{ Deflection (in.) } & \multicolumn{2}{|c|}{$\begin{array}{c}\text { Calc. - Meas. } \\
\text { ratio }\end{array}$} \\
\hline & & \multirow[b]{2}{*}{ meas. } & \multicolumn{2}{|c|}{ Calculated } & \multirow[b]{2}{*}{$\mathrm{V}$} & \multirow[b]{2}{*}{ NV } \\
\hline & & & v & $\mathrm{NV}$ & & \\
\hline 1 & $\overline{2.04}$ & $\overline{0.256}$ & $\overline{0.268}$ & $\overline{0.230}$ & $\overline{1.05}$ & $\overline{0.90}$ \\
\hline 2 & 3.78 & 0.305 & 0.276 & 0.236 & 0.90 & 0.77 \\
\hline 3 & 26.30 & 0.447 & 0.460 & 0.410 & 1.03 & 0.92 \\
\hline $5 \mathrm{a}$ & 3.78 & 0.244 & 0.286 & 0.226 & 1.17 & 0.93 \\
\hline $5 \mathrm{~b}$ & 3.78 & 0.303 & 0.260 & 0.224 & 0.86 & 0.74 \\
\hline $6 a$ & 0.00 & 0.107 & 0.072 & 0.046 & 0.67 & 0.43 \\
\hline $6 \mathrm{~b}$ & 2.04 & 0.246 & 0.234 & 0.194 & 0.95 & 0.79 \\
\hline $7 \mathbf{a}$ & 2.04 & 0.321 & 0.346 & 0.308 & 1.08 & 0.96 \\
\hline $7 \mathrm{~b}$ & 3.78 & 0.409 & 0.430 & 0.380 & 1.05 & 0.93 \\
\hline $8 a$ & 3.89 & 0.159 & 0.204 & 0.170 & 1.28 & 1.07 \\
\hline $8 b$ & 2.90 & 0.146 & 0.166 & 0.136 & 1.14 & 0.93 \\
\hline $9 \mathrm{a}$ & 2.04 & 0.152 & 0.164 & 0.130 & 1,08 & 0.86 \\
\hline $9 b$ & 1.75 & 0.223 & 0.188 & 0.146 & 0.84 & 0.65 \\
\hline $\mathrm{cl}$ & 6.00 & 0.836 & 0.780 & 0.724 & 0.93 & 0.87 \\
\hline $\mathrm{c} 2$ & 6.04 & 0.643 & 0,602 & 0.554 & 0.94 & 0.86 \\
\hline $\mathrm{c} 3$ & 22.15 & 0.679 & 0.650 & 0.596 & 0.96 & 0.88 \\
\hline $\mathrm{c} 4$ & 2.01 & 0.216 & 0.212 & 0.170 & 0.98 & 0.79 \\
\hline$c 5$ & 3.97 & 0.403 & 0.464 & 0.414 & 1.15 & 1.03 \\
\hline c6 & 2.57 & 0.277 & 0.306 & 0.256 & 1.10 & 0.92 \\
\hline 10 & 3.94 & 0.272 & 0.324 & 0.284 & 1.19 & 1.04 \\
\hline $\mathrm{n}$ & 2.66 & 0.230 & 0.160 & 0.128 & 0.70 & 0.56 \\
\hline 2 & 7.00 & 0.453 & 0.496 & 0.438 & 1.09 & 0.97 \\
\hline 53 & 16.83 & 0.585 & 0.422 & 0.366 & 0.72 & 0.63 \\
\hline 81 & 3.00 & 0.216 & 0.222 & 0.178 & 1.03 & 0.82 \\
\hline \multirow[t]{4}{*}{82} & 6.00 & 0.255 & 0.264 & 0.214 & 1.04 & 0.84 \\
\hline & & \multirow{3}{*}{\multicolumn{3}{|c|}{$\begin{array}{l}\text { Mean } \\
\text { Std. Dev. } \\
\text { Coef. of Var. }\end{array}$}} & 1.00 & 0.84 \\
\hline & & & & & 0.15 & 0.15 \\
\hline & & & & & 15.16 & 17.62 \\
\hline
\end{tabular}

\begin{tabular}{|c|c|c|c|c|}
\hline \multicolumn{3}{|c|}{ Deflection (in.) } & \multicolumn{2}{|c|}{$\begin{array}{c}\text { Calc. - Meas. } \\
\text { ratio }\end{array}$} \\
\hline \multirow[b]{2}{*}{ meas. } & \multicolumn{2}{|c|}{ Calculated } & \multirow[b]{2}{*}{ V } & \multirow[b]{2}{*}{ NV } \\
\hline & V & NV & & \\
\hline 0.170 & 0.110 & $\overline{0.090}$ & 0.65 & 0.53 \\
\hline 0.161 & 0.086 & 0.066 & 0.53 & 0.41 \\
\hline 0.088 & 0.034 & 0.028 & 0.39 & 0.32 \\
\hline 0.127 & 0.080 & 0.054 & 0.63 & 0.43 \\
\hline 0.214 & 0.088 & 0.064 & 0.41 & 0.30 \\
\hline 0.149 & 0.066 & 0.046 & 0.44 & 0.31 \\
\hline 0.162 & 0.118 & 0.092 & 0.73 & 0.57 \\
\hline 0.150 & 0.132 & 0.110 & 0.88 & 0.73 \\
\hline 0.130 & 0.120 & 0.098 & 0.92 & 0.75 \\
\hline 0.090 & 0.058 & 0.042 & 0.64 & 0.47 \\
\hline 0.102 & 0.098 & 0.078 & 0.96 & 0.76 \\
\hline 0.174 & 0.104 & 0.078 & 0.60 & 0.45 \\
\hline 0.130 & 0.062 & 0.040 & 0.48 & 0.31 \\
\hline 0.034 & 0.114 & 0.092 & 3.35 & 2.71 \\
\hline 0.154 & 0.096 & 0.078 & 0.62 & 0.51 \\
\hline 0.073 & 0.058 & 0.050 & 0.79 & 0.68 \\
\hline 0.058 & 0.112 & 0.086 & 133 & 1.48 \\
\hline 0.139 & 0.124 & 0.100 & 0.89 & 0.72 \\
\hline 0.116 & 0.104 & 0.080 & 0.90 & 0.69 \\
\hline 0.062 & 0.076 & 0.058 & 1.23 & 0.94 \\
\hline 0.115 & 0.064 & 0.046 & 0.56 & 0.40 \\
\hline 0.096 & 0.068 & 0.048 & 0.71 & 0.50 \\
\hline \multirow[t]{4}{*}{0.033} & 0.016 & 0.006 & 0.48 & 0.18 \\
\hline & \multirow{3}{*}{\multicolumn{2}{|c|}{$\begin{array}{l}\text { Mean } \\
\text { Std. Dev. } \\
\text { Coef. of Var. }\end{array}$}} & 0.77 & 0.59 \\
\hline & & & 0.35 & 0.28 \\
\hline & & & 45.06 & 47.11 \\
\hline
\end{tabular}


Table B1. Case study for deflections across the opening for the W $24 \times 55$ section including shear deformations

\begin{tabular}{|c|c|c|c|c|c|c|c|c|c|}
\hline \multirow[b]{2}{*}{$\frac{h_{o}}{d}$} & \multirow[b]{2}{*}{$\frac{a_{0}}{h_{0}}$} & \multirow[b]{2}{*}{$\frac{\mathrm{L}_{o}}{\mathrm{~L}_{\mathrm{y}}}$} & \multirow{2}{*}{$\frac{\begin{array}{c}\text { total } \\
\text { deflection }\end{array}}{\Delta_{y}}$} & \multicolumn{2}{|c|}{$\begin{array}{l}\text { deflection due to } \\
\text { rotation, } \theta\end{array}$} & \multicolumn{2}{|c|}{$\begin{array}{l}\text { deflection due to } \\
\text { shear load, P }\end{array}$} & \multicolumn{2}{|c|}{$\begin{array}{l}\text { deflection due to } \\
\text { moment, } \mathrm{M}\end{array}$} \\
\hline & & & & $\Delta_{y}^{(\theta)}$ & $\frac{\Delta_{y}^{(\theta)}}{\Delta_{y}}$ & $\Delta_{f}^{(p)}$ & $\frac{\Delta_{y}^{(p)}}{\Delta_{y}}$ & $\Delta_{y}^{(M)}$ & $\frac{\Delta_{y}^{(M)}}{\Delta_{y}}$ \\
\hline 0.3 & 1 & $\begin{array}{l}1 / 16 \\
1 / 8 \\
1 / 4 \\
3 / 8\end{array}$ & $\begin{array}{l}-0.048330 \\
-0.044870 \\
-0.033360 \\
-0.017560\end{array}$ & $\begin{array}{l}-0.045530 \\
-0.042810 \\
-0.032640 \\
-0.018000\end{array}$ & $\begin{array}{l}0.942 \\
0.954 \\
0.978 \\
1.025\end{array}$ & $\begin{array}{l}-0.003160 \\
-0.002700 \\
-0.001780 \\
-0.000860\end{array}$ & $\begin{array}{l}0.065 \\
0.060 \\
0.053 \\
0.049\end{array}$ & $\begin{array}{l}0.000359 \\
0.000634 \\
0.001055 \\
0.001303\end{array}$ & $\begin{array}{l}-0.007 \\
-0.014 \\
-0.032 \\
-0.074\end{array}$ \\
\hline & 2 & $\begin{array}{l}1 / 16 \\
1 / 8 \\
1 / 4 \\
3 / 8\end{array}$ & $\begin{array}{l}-0.097710 \\
-0.090450 \\
-0.066820 \\
-0.034680\end{array}$ & $\begin{array}{l}-0.091470 \\
-0.086460 \\
-0.066800 \\
-0.037940\end{array}$ & $\begin{array}{l}0.936 \\
0.956 \\
1.000 \\
1.094\end{array}$ & $\begin{array}{l}-0.007840 \\
-0.006680 \\
-0.004360 \\
-0.002040\end{array}$ & $\begin{array}{l}0.080 \\
0.074 \\
0.065 \\
0.059\end{array}$ & $\begin{array}{l}0.001594 \\
0.002683 \\
0.004338 \\
0.005298\end{array}$ & $\begin{array}{l}-0.016 \\
-0.030 \\
-0.065 \\
-0.153\end{array}$ \\
\hline & 3 & $\begin{array}{l}1 / 16 \\
1 / 8 \\
1 / 4 \\
3 / 8\end{array}$ & $\begin{array}{l}-0.149210 \\
-0.137610 \\
-0.100870 \\
-0.051490\end{array}$ & $\begin{array}{l}-0.137730 \\
-0.130880 \\
-0.102450 \\
-0.059790\end{array}$ & $\begin{array}{l}0.923 \\
0.951 \\
1.016 \\
1.161\end{array}$ & $\begin{array}{r}-0.015420 \\
-0.013100 \\
-0.008450 \\
-0.003800\end{array}$ & $\begin{array}{l}0.103 \\
0.095 \\
0.084 \\
0.074\end{array}$ & $\begin{array}{l}0.003940 \\
0.006364 \\
0.010028 \\
0.012112\end{array}$ & $\begin{array}{l}-0.026 \\
-0.046 \\
-0.099 \\
-0.235\end{array}$ \\
\hline 0.5 & 1 & $\begin{array}{c}1 / 16 \\
1 / 8 \\
1 / 4 \\
3 / 8\end{array}$ & $\begin{array}{l}-0.084310 \\
-0.077800 \\
-0.057210 \\
-0.029540\end{array}$ & $\begin{array}{l}-0.076120 \\
-0.071820 \\
-0.055250 \\
-0.031080\end{array}$ & $\begin{array}{l}0.903 \\
0.923 \\
0.966 \\
1.052\end{array}$ & $\begin{array}{r}-0.009360 \\
-0.007980 \\
-0.005230 \\
-0.002480\end{array}$ & $\begin{array}{l}0.111 \\
0.103 \\
0.091 \\
0.084\end{array}$ & $\begin{array}{l}0.001174 \\
0.002006 \\
0.003273 \\
0.004012\end{array}$ & $\begin{array}{l}-0.014 \\
-0.026 \\
-0.057 \\
-0.136\end{array}$ \\
\hline & 2 & $\begin{array}{c}1 / 16 \\
1 / 8 \\
1 / 4 \\
3 / 8\end{array}$ & $\begin{array}{r}-0.180090 \\
-0.164510 \\
-0.118500 \\
-0.058710\end{array}$ & $\begin{array}{l}-0.153210 \\
-0.145850 \\
-0.114650 \\
-0.067500\end{array}$ & $\begin{array}{l}0.851 \\
0.887 \\
0.967 \\
1.150\end{array}$ & $\begin{array}{r}-0.032420 \\
-0.027510 \\
-0.017680 \\
-0.007850\end{array}$ & $\begin{array}{l}0.180 \\
0.167 \\
0.149 \\
0.134\end{array}$ & $\begin{array}{l}0.005545 \\
0.008846 \\
0.013825 \\
0.016637\end{array}$ & $\begin{array}{l}-0.031 \\
-0.054 \\
-0.117 \\
-0.283\end{array}$ \\
\hline & 3 & $\begin{array}{l}1 / 16 \\
1 / 8 \\
1 / 4 \\
3 / 8\end{array}$ & $\begin{array}{l}-0.296590 \\
-0.267690 \\
-0.188050 \\
-0.088330\end{array}$ & $\begin{array}{l}-0.230870 \\
-0.221740 \\
-0.177950 \\
-0.109150\end{array}$ & $\begin{array}{l}0.778 \\
0.828 \\
0.946 \\
1.236\end{array}$ & $\begin{array}{r}-0.079960 \\
-0.067460 \\
-0.042450 \\
-0.017450\end{array}$ & $\begin{array}{l}0.270 \\
0.252 \\
0.226 \\
0.198\end{array}$ & $\begin{array}{l}0.014242 \\
0.021513 \\
0.032356 \\
0.038265\end{array}$ & $\begin{array}{l}-0.048 \\
-0.080 \\
-0.172 \\
-0.433\end{array}$ \\
\hline 0.7 & 1 & $\begin{array}{l}1 / 16 \\
1 / 8 \\
1 / 4 \\
3 / 8\end{array}$ & $\begin{array}{l}-0.141170 \\
-0.128040 \\
-0.091380 \\
-0.045110\end{array}$ & $\begin{array}{l}-0.106860 \\
-0.101180 \\
-0.078520 \\
-0.045010\end{array}$ & $\begin{array}{l}0.757 \\
0.790 \\
0.859 \\
0.998\end{array}$ & $\begin{array}{l}-0.037220 \\
-0.031680 \\
-0.020600 \\
-0.009520\end{array}$ & $\begin{array}{l}0.264 \\
0.247 \\
0.225 \\
0.211\end{array}$ & $\begin{array}{l}0.002911 \\
0.004829 \\
0.007740 \\
0.009417\end{array}$ & $\begin{array}{l}-0.021 \\
-0.038 \\
-0.085 \\
-0.209\end{array}$ \\
\hline & 2 & $\begin{array}{l}1 / 16 \\
1 / 8 \\
1 / 4 \\
3 / 8\end{array}$ & $\begin{array}{r}-0.376670 \\
-0.332990 \\
-0.225740 \\
-0.100420\end{array}$ & $\begin{array}{l}-0.215310 \\
-0.206430 \\
-0.164990 \\
-0.100410\end{array}$ & $\begin{array}{l}0.572 \\
0.620 \\
0.731 \\
1.000\end{array}$ & $\begin{array}{l}-0.175640 \\
-0.148350 \\
-0.093770 \\
-0.039190\end{array}$ & $\begin{array}{l}0.466 \\
0.446 \\
0.415 \\
0.390\end{array}$ & $\begin{array}{l}0.014281 \\
0.021790 \\
0.033013 \\
0.039176\end{array}$ & $\begin{array}{l}-0.038 \\
-0.065 \\
-0.146 \\
-0.390\end{array}$ \\
\hline & 3 & $\begin{array}{c}1 / 16 \\
1 / 8 \\
1 / 4 \\
3 / 8\end{array}$ & $\begin{array}{l}-0.782410 \\
-0.676210 \\
-0.435280 \\
-0.168970\end{array}$ & $\begin{array}{l}-0.324200 \\
-0.314750 \\
-0.258700 \\
-0.165800\end{array}$ & $\begin{array}{l}0.414 \\
0.465 \\
0.594 \\
0.981\end{array}$ & $\begin{array}{r}-0.495630 \\
-0.415090 \\
-0.254010 \\
-0.092930\end{array}$ & $\begin{array}{l}0.633 \\
0.614 \\
0.584 \\
0.550\end{array}$ & $\begin{array}{l}0.037428 \\
0.053625 \\
0.077425 \\
0.089766\end{array}$ & $\begin{array}{l}-0.048 \\
-0.079 \\
-0.178 \\
-0.531\end{array}$ \\
\hline
\end{tabular}


Table B2. Case study for deflections across the opening for the $\mathrm{W} 18 \times 35$ section including shear deformations

\begin{tabular}{|c|c|c|c|c|c|c|c|c|c|}
\hline \multirow[b]{2}{*}{$\frac{h_{0}}{d}$} & \multirow[b]{2}{*}{$\frac{\mathrm{a}_{0}}{\mathrm{~h}_{0}}$} & \multirow[b]{2}{*}{$\frac{\mathrm{L}_{0}}{\mathrm{~L}_{8}}$} & \multirow{2}{*}{$\frac{\begin{array}{c}\text { total } \\
\text { deflection }\end{array}}{\Delta y}$} & \multicolumn{2}{|c|}{$\begin{array}{l}\text { deflection due to } \\
\text { rotation, } \theta\end{array}$} & \multicolumn{2}{|c|}{$\begin{array}{l}\text { deflection due to } \\
\text { shear load, P }\end{array}$} & \multicolumn{2}{|c|}{$\begin{array}{l}\text { deflection due to } \\
\text { moment, } \mathrm{M}\end{array}$} \\
\hline & & & & $\Delta_{y}^{(0)}$ & $\frac{\Delta_{y}^{(0)}}{\Delta_{y}}$ & $\Delta_{y}^{(P)}$ & $\frac{\Delta_{y}^{(P)}}{\Delta_{\gamma}}$ & $\Delta_{y}^{(M)}$ & $\frac{\Delta_{y}^{(M)}}{\Delta_{y}}$ \\
\hline 0.3 & 1 & $\begin{array}{c}1 / 16 \\
1 / 8 \\
1 / 4 \\
3 / 8\end{array}$ & $\begin{array}{l}-0.039200 \\
-0.036350 \\
-0.026970 \\
-0.014160\end{array}$ & $\begin{array}{l}-0.036380 \\
-0.034200 \\
-0.026070 \\
-0.014360\end{array}$ & $\begin{array}{l}0.928 \\
0.941 \\
0.967 \\
1.014\end{array}$ & $\begin{array}{l}-0.003110 \\
-0.002660 \\
-0.001750 \\
-0.000850\end{array}$ & $\begin{array}{l}0.079 \\
0.073 \\
0.065 \\
0.060\end{array}$ & $\begin{array}{l}0.000290 \\
0.000512 \\
0.000852 \\
0.001052\end{array}$ & $\begin{array}{l}-0.007 \\
-0.014 \\
-0.032 \\
-0.074\end{array}$ \\
\hline & 2 & $\begin{array}{l}1 / 16 \\
1 / 8 \\
1 / 4 \\
3 / 8\end{array}$ & $\begin{array}{l}-0.079320 \\
-0.073300 \\
-0.054010 \\
-0.027920\end{array}$ & $\begin{array}{r}-0.073080 \\
-0.069060 \\
-0.053330 \\
-0.030240\end{array}$ & $\begin{array}{l}0.921 \\
0.942 \\
0.987 \\
1.083\end{array}$ & $\begin{array}{l}-0.007520 \\
-0.006410 \\
-0.004190 \\
-0.001960\end{array}$ & $\begin{array}{l}0.095 \\
0.087 \\
0.078 \\
0.070\end{array}$ & $\begin{array}{l}0.001285 \\
0.002167 \\
0.003509 \\
0.004288\end{array}$ & $\begin{array}{l}-0.016 \\
-0.030 \\
-0.065 \\
-0.154\end{array}$ \\
\hline & 3 & $\begin{array}{l}1 / 16 \\
1 / 8 \\
1 / 4 \\
3 / 8\end{array}$ & $\begin{array}{l}-0.121236 \\
-0.111590 \\
-0.081500 \\
-0.041350\end{array}$ & $\begin{array}{l}-0.110042 \\
-0.104530 \\
-0.081740 \\
-0.047620\end{array}$ & $\begin{array}{l}0.908 \\
0.937 \\
1.003 \\
1.152\end{array}$ & $\begin{array}{l}-0.014374 \\
-0.012210 \\
-0.007890 \\
-0.003560\end{array}$ & $\begin{array}{l}0.119 \\
0.109 \\
0.097 \\
0.086\end{array}$ & $\begin{array}{l}0.003180 \\
0.005152 \\
0.008132 \\
0.009829\end{array}$ & $\begin{array}{l}-0.026 \\
-0.046 \\
-0.100 \\
-0.238\end{array}$ \\
\hline 0.5 & 1 & $\begin{array}{c}1 / 16 \\
1 / 8 \\
1 / 4 \\
3 / 8\end{array}$ & $\begin{array}{l}-0.068870 \\
-0.063430 \\
-0.046500 \\
-0.023930\end{array}$ & $\begin{array}{r}-0.060820 \\
-0.057370 \\
-0.044110 \\
-0.024780\end{array}$ & $\begin{array}{l}0.883 \\
0.904 \\
0.949 \\
1.035\end{array}$ & $\begin{array}{r}-0.008990 \\
-0.007670 \\
-0.005030 \\
-0.002380\end{array}$ & $\begin{array}{l}0.131 \\
0.121 \\
0.108 \\
0.100\end{array}$ & $\begin{array}{l}0.000943 \\
0.001613 \\
0.002636 \\
0.003232\end{array}$ & $\begin{array}{l}-0.014 \\
-0.025 \\
-0.057 \\
-0.135\end{array}$ \\
\hline & 2 & $\begin{array}{c}1 / 16 \\
1 / 8 \\
1 / 4 \\
3 / 8\end{array}$ & $\begin{array}{l}-0.147271 \\
-0.134220 \\
-0.096280 \\
-0.047390\end{array}$ & $\begin{array}{l}-0.122400 \\
-0.116470 \\
-0.091460 \\
-0.053740\end{array}$ & $\begin{array}{l}0.831 \\
0.868 \\
0.950 \\
1.134\end{array}$ & $\begin{array}{l}-0.029341 \\
-0.024900 \\
-0.016020 \\
-0.007140\end{array}$ & $\begin{array}{l}0.199 \\
0.186 \\
0.166 \\
0.151\end{array}$ & $\begin{array}{l}0.004470 \\
0.007152 \\
0.011199 \\
0.013489\end{array}$ & $\begin{array}{l}-0.030 \\
-0.053 \\
-0.116 \\
-0.285\end{array}$ \\
\hline & 3 & $\begin{array}{l}1 / 16 \\
1 / 8 \\
1 / 4 \\
3 / 8\end{array}$ & $\begin{array}{l}-0.242120 \\
-0.217980 \\
-0.152370 \\
-0.070850\end{array}$ & $\begin{array}{l}-0.184450 \\
-0.177040 \\
-0.141870 \\
-0.086780\end{array}$ & $\begin{array}{l}0.762 \\
0.812 \\
0.931 \\
1.225\end{array}$ & $\begin{array}{l}-0.069180 \\
-0.058380 \\
-0.036800 \\
-0.015220\end{array}$ & $\begin{array}{l}0.286 \\
0.268 \\
0.242 \\
0.215\end{array}$ & $\begin{array}{l}0.011506 \\
0.017442 \\
0.026301 \\
0.031143\end{array}$ & $\begin{array}{l}-0.048 \\
-0.080 \\
-0.173 \\
-0.440\end{array}$ \\
\hline 0.7 & 1 & $\begin{array}{l}1 / 16 \\
1 / 8 \\
1 / 4 \\
3 / 8\end{array}$ & $\begin{array}{l}-0.117670 \\
-0.106450 \\
-0.075700 \\
-0.037280\end{array}$ & $\begin{array}{r}-0.085380 \\
-0.080820 \\
-0.062670 \\
-0.035870\end{array}$ & $\begin{array}{l}0.726 \\
0.759 \\
0.828 \\
0.962\end{array}$ & $\begin{array}{r}-0.034590 \\
-0.029440 \\
-0.019160 \\
-0.008870\end{array}$ & $\begin{array}{l}0.294 \\
0.277 \\
0.253 \\
0.238\end{array}$ & $\begin{array}{l}0.002295 \\
0.003817 \\
0.006127 \\
0.007459\end{array}$ & $\begin{array}{l}-0.020 \\
-0.036 \\
-0.081 \\
-0.200\end{array}$ \\
\hline & 2 & $\begin{array}{l}1 / 16 \\
1 / 8 \\
1 / 4 \\
3 / 8\end{array}$ & $\begin{array}{l}-0.313640 \\
-0.276750 \\
-0.187120 \\
-0.083070\end{array}$ & $\begin{array}{l}-0.172020 \\
-0.164830 \\
-0.131550 \\
-0.079850\end{array}$ & $\begin{array}{l}0.548 \\
0.596 \\
0.703 \\
0.961\end{array}$ & $\begin{array}{l}-0.152890 \\
-0.129180 \\
-0.081770 \\
-0.034360\end{array}$ & $\begin{array}{l}0.487 \\
0.467 \\
0.437 \\
0.414\end{array}$ & $\begin{array}{l}0.011271 \\
0.017257 \\
0.026210 \\
0.031138\end{array}$ & $\begin{array}{l}-0.036 \\
-0.062 \\
-0.140 \\
-0.375\end{array}$ \\
\hline & 3 & $\begin{array}{l}1 / 16 \\
1 / 8 \\
1 / 4 \\
3 / 8\end{array}$ & $\begin{array}{l}-0.649393 \\
-0.560665 \\
-0.360465 \\
-0.140067\end{array}$ & $\begin{array}{r}-0.259047 \\
-0.251265 \\
-0.206116 \\
-0.131646\end{array}$ & $\begin{array}{l}0.399 \\
0.448 \\
0.572 \\
0.940\end{array}$ & $\begin{array}{r}-0.419863 \\
-0.351858 \\
-0.215848 \\
-0.079838\end{array}$ & $\begin{array}{l}0.647 \\
0.628 \\
0.599 \\
0.570\end{array}$ & $\begin{array}{l}0.029517 \\
0.042458 \\
0.061499 \\
0.071417\end{array}$ & $\begin{array}{l}-0.045 \\
-0.076 \\
-0.171 \\
-0.510\end{array}$ \\
\hline
\end{tabular}


Table B3. Case study for deflections across the opening for the $\mathrm{W} 14 \times 22$ section including shear deformations

\begin{tabular}{|c|c|c|c|c|c|c|c|c|c|}
\hline \multirow[b]{2}{*}{$\frac{h_{0}}{d}$} & \multirow[b]{2}{*}{$\frac{a_{0}}{h_{0}}$} & \multirow[b]{2}{*}{$\frac{\mathrm{L}_{\mathrm{o}}}{\mathrm{L}_{\mathrm{s}}}$} & \multirow{2}{*}{$\frac{\begin{array}{c}\text { total } \\
\text { deflection }\end{array}}{\Delta_{y}}$} & \multicolumn{2}{|c|}{$\begin{array}{l}\text { deflection due to } \\
\text { rotation, } \theta\end{array}$} & \multicolumn{2}{|c|}{$\begin{array}{c}\text { deflection due to } \\
\text { shear load, P }\end{array}$} & \multicolumn{2}{|c|}{$\begin{array}{c}\text { deflection due to } \\
\text { moment, } \mathrm{M}\end{array}$} \\
\hline & & & & $\Delta_{y}^{(\theta)}$ & $\frac{\Delta_{y}^{(9)}}{\Delta_{y}}$ & $\Delta_{f}^{\left.()^{\prime}\right)}$ & $\frac{\Delta_{y}^{(p)}}{\Delta_{y}}$ & $\Delta_{g}^{(M)}$ & $\frac{\Delta_{y}^{(M)}}{\Delta_{y}}$ \\
\hline 0.3 & 1 & $\begin{array}{l}1 / 16 \\
1 / 8 \\
1 / 4 \\
3 / 8\end{array}$ & $\begin{array}{l}-0.024710 \\
-0.022830 \\
-0.016850 \\
-0.008800\end{array}$ & $\begin{array}{l}-0.022120 \\
-0.020800 \\
-0.015880 \\
-0.008780\end{array}$ & $\begin{array}{l}0.895 \\
0.911 \\
0.942 \\
0.998\end{array}$ & $\begin{array}{l}-0.002800 \\
-0.002390 \\
-0.001580 \\
-0.000760\end{array}$ & $\begin{array}{l}0.113 \\
0.105 \\
0.094 \\
0.087\end{array}$ & $\begin{array}{l}0.000206 \\
0.000362 \\
0.000601 \\
0.000742\end{array}$ & $\begin{array}{l}-0.008 \\
-0.016 \\
-0.036 \\
-0.084\end{array}$ \\
\hline & 2 & $\begin{array}{l}1 / 16 \\
1 / 8 \\
1 / 4 \\
3 / 8\end{array}$ & $\begin{array}{l}-0.050170 \\
-0.046160 \\
-0.033760 \\
-0.017260\end{array}$ & $\begin{array}{l}-0.044440 \\
-0.042040 \\
-0.032560 \\
-0.018570\end{array}$ & $\begin{array}{l}0.886 \\
0.911 \\
0.964 \\
1.076\end{array}$ & $\begin{array}{l}-0.006650 \\
-0.005660 \\
-0.003690 \\
-0.001720\end{array}$ & $\begin{array}{l}0.133 \\
0.123 \\
0.109 \\
0.099\end{array}$ & $\begin{array}{l}0.000925 \\
0.001545 \\
0.002487 \\
0.003032\end{array}$ & $\begin{array}{l}-0.018 \\
-0.033 \\
-0.074 \\
-0.176\end{array}$ \\
\hline & 3 & $\begin{array}{l}1 / 16 \\
1 / 8 \\
1 / 4 \\
3 / 8\end{array}$ & $\begin{array}{l}-0.077050 \\
-0.070540 \\
-0.051000 \\
-0.025430\end{array}$ & $\begin{array}{r}-0.066930 \\
-0.063680 \\
-0.050000 \\
-0.029380\end{array}$ & $\begin{array}{l}0.869 \\
0.903 \\
0.980 \\
1.155\end{array}$ & $\begin{array}{l}-0.012430 \\
-0.010550 \\
-0.006790 \\
-0.003020\end{array}$ & $\begin{array}{l}0.161 \\
0.150 \\
0.133 \\
0.119\end{array}$ & $\begin{array}{l}0.002309 \\
0.003696 \\
0.005788 \\
0.006972\end{array}$ & $\begin{array}{l}-0.030 \\
-0.052 \\
-0.113 \\
-0.274\end{array}$ \\
\hline 0.5 & 1 & $\begin{array}{l}1 / 16 \\
1 / 8 \\
1 / 4 \\
3 / 8\end{array}$ & $\begin{array}{l}-0.044280 \\
-0.040570 \\
-0.012790 \\
-0.015020\end{array}$ & $\begin{array}{r}-0.036980 \\
-0.034910 \\
-0.026910 \\
-0.015200\end{array}$ & $\begin{array}{l}0.835 \\
0.861 \\
2.105 \\
1.012\end{array}$ & $\begin{array}{l}-0.007970 \\
-0.006800 \\
-0.004450 \\
-0.002100\end{array}$ & $\begin{array}{l}0.180 \\
0.168 \\
0.348 \\
0.140\end{array}$ & $\begin{array}{l}0.000673 \\
0.001142 \\
0.018570 \\
0.002273\end{array}$ & $\begin{array}{l}-0.015 \\
-0.028 \\
-1.452 \\
-0.151\end{array}$ \\
\hline & 2 & $\begin{array}{l}1 / 16 \\
1 / 8 \\
1 / 4 \\
3 / 8\end{array}$ & $\begin{array}{l}-0.096140 \\
-0.086990 \\
-0.061570 \\
-0.029600\end{array}$ & $\begin{array}{l}-0.074450 \\
-0.070980 \\
-0.055990 \\
-0.033200\end{array}$ & $\begin{array}{l}0.774 \\
0.816 \\
0.909 \\
1.122\end{array}$ & $\begin{array}{l}-0.024930 \\
-0.021130 \\
-0.013540 \\
-0.005940\end{array}$ & $\begin{array}{l}0.259 \\
0.243 \\
0.220 \\
0.201\end{array}$ & $\begin{array}{l}0.003241 \\
0.005120 \\
0.007949 \\
0.009538\end{array}$ & $\begin{array}{l}-0.034 \\
-0.059 \\
-0.129 \\
-0.322\end{array}$ \\
\hline & 3 & $\begin{array}{l}1 / 16 \\
1 / 8 \\
1 / 4 \\
3 / 8\end{array}$ & $\begin{array}{l}.0 .160360 \\
-0.143090 \\
-0.098320 \\
-0.043840\end{array}$ & $\begin{array}{r}-0.112180 \\
-0.107990 \\
-0.087100 \\
-0.053930\end{array}$ & $\begin{array}{l}0.700 \\
0.755 \\
0.886 \\
1.230\end{array}$ & $\begin{array}{l}-0.056600 \\
-0.047680 \\
-0.029840 \\
-0.012000\end{array}$ & $\begin{array}{l}0.353 \\
0.333 \\
0.304 \\
0.274\end{array}$ & $\begin{array}{l}0.008432 \\
0.012586 \\
0.018624 \\
0.022096\end{array}$ & $\begin{array}{l}-0.053 \\
-0.088 \\
-0.189 \\
-0.504\end{array}$ \\
\hline 0.7 & 1 & $\begin{array}{l}1 / 16 \\
1 / 8 \\
1 / 4 \\
3 / 8\end{array}$ & $\begin{array}{l}-0.080450 \\
-0.072180 \\
-0.050650 \\
-0.024510\end{array}$ & $\begin{array}{l}-0.051920 \\
-0.049210 \\
-0.038290 \\
-0.022060\end{array}$ & $\begin{array}{l}0.645 \\
0.682 \\
0.756 \\
0.900\end{array}$ & $\begin{array}{l}-0.030160 \\
-0.025650 \\
-0.016640 \\
-0.007630\end{array}$ & $\begin{array}{l}0.375 \\
0.355 \\
0.329 \\
0.311\end{array}$ & $\begin{array}{l}0.001629 \\
0.002682 \\
0.004277 \\
0.005192\end{array}$ & $\begin{array}{l}-0.020 \\
-0.037 \\
-0.084 \\
-0.212\end{array}$ \\
\hline & 2 & $\begin{array}{l}1 / 16 \\
1 / 8 \\
1 / 4 \\
3 / 8\end{array}$ & $\begin{array}{l}-0.224210 \\
-0.195990 \\
-0.130060 \\
-0.055600\end{array}$ & $\begin{array}{l}-0.104630 \\
-0.100520 \\
-0.080720 \\
-0.049570\end{array}$ & $\begin{array}{l}0.467 \\
0.513 \\
0.621 \\
0.892\end{array}$ & $\begin{array}{l}-0.127700 \\
-0.107710 \\
-0.067740 \\
-0.027770\end{array}$ & $\begin{array}{l}0.570 \\
0.550 \\
0.521 \\
0.499\end{array}$ & $\begin{array}{l}0.008118 \\
0.012244 \\
0.018395 \\
0.021742\end{array}$ & $\begin{array}{l}-0.036 \\
-0.062 \\
-0.141 \\
-0.391\end{array}$ \\
\hline & 3 & $\begin{array}{l}1 / 16 \\
1 / 8 \\
1 / 4 \\
3 / 8\end{array}$ & $\begin{array}{l}-0.478720 \\
-0.409400 \\
-0.257310 \\
-0.093430\end{array}$ & $\begin{array}{l}-0.157470 \\
-0.153350 \\
-0.126900 \\
-0.082300\end{array}$ & $\begin{array}{l}0.329 \\
0.375 \\
0.493 \\
0.881\end{array}$ & $\begin{array}{r}-0.342700 \\
-0.286370 \\
-0.173710 \\
-0.061060\end{array}$ & $\begin{array}{l}0.716 \\
0.699 \\
0.675 \\
0.654\end{array}$ & $\begin{array}{l}0.021442 \\
0.030317 \\
0.043297 \\
0.049921\end{array}$ & $\begin{array}{l}-0.045 \\
-0.074 \\
-0.168 \\
-0.534\end{array}$ \\
\hline
\end{tabular}


Table B4. Case study for deflections across the opening for the W $24 \times 55$ section neglecting shear deformations

\begin{tabular}{|c|c|c|c|c|c|c|c|c|c|}
\hline \multirow[b]{2}{*}{$\frac{h_{0}}{d}$} & \multirow[b]{2}{*}{$\frac{a_{0}}{h_{0}}$} & \multirow[b]{2}{*}{$\frac{\mathrm{L}_{\mathrm{o}}}{\mathrm{L}_{\mathrm{z}}}$} & \multirow{2}{*}{$\frac{\begin{array}{c}\text { total } \\
\text { deflection }\end{array}}{\Delta_{y, b}}$} & \multicolumn{2}{|c|}{$\begin{array}{l}\text { deflection due to } \\
\text { rotation, } \theta\end{array}$} & \multicolumn{2}{|c|}{$\begin{array}{l}\text { deflection due to } \\
\text { shear load, } \mathrm{P}\end{array}$} & \multicolumn{2}{|c|}{$\begin{array}{l}\text { deflection due to } \\
\text { moment, } \mathrm{M}\end{array}$} \\
\hline & & & & $\Delta_{y}^{(\theta)}$ & $\frac{\Delta_{y}^{(0)}}{\Delta_{y, b}}$ & $\Delta_{y, b}^{(P)}$ & $\frac{\Delta_{y, b}^{(P)}}{\Delta_{y, b}}$ & $\Delta_{y, b}^{(M)}$ & $\frac{\Delta_{y, b}^{(M)}}{\Delta_{y, b}}$ \\
\hline 0.3 & 1 & $\begin{array}{l}1 / 16 \\
1 / 8 \\
1 / 4 \\
3 / 8\end{array}$ & $\begin{array}{l}-0.045410 \\
-0.042360 \\
-0.031680 \\
-0.016700\end{array}$ & $\begin{array}{l}-0.045530 \\
-0.042810 \\
-0.032640 \\
-0.018000\end{array}$ & $\begin{array}{l}1.003 \\
1.011 \\
1.030 \\
1.078\end{array}$ & $\begin{array}{l}-0.000250 \\
-0.000220 \\
-0.000140 \\
-0.000069\end{array}$ & $\begin{array}{l}0.006 \\
0.005 \\
0.004 \\
0.004\end{array}$ & $\begin{array}{l}0.000377 \\
0.000665 \\
0.001105 \\
0.001365\end{array}$ & $\begin{array}{l}-0.008 \\
-0.016 \\
-0.035 \\
-0.082\end{array}$ \\
\hline & 2 & $\begin{array}{l}1 / 16 \\
1 / 8 \\
1 / 4 \\
3 / 8\end{array}$ & $\begin{array}{l}-0.091800 \\
-0.085360 \\
-0.063400 \\
-0.032950\end{array}$ & $\begin{array}{r}-0.091470 \\
-0.086460 \\
-0.066800 \\
-0.037940\end{array}$ & $\begin{array}{l}0.996 \\
1.013 \\
1.054 \\
1.151\end{array}$ & $\begin{array}{l}-0.001990 \\
-0.001690 \\
-0.001100 \\
-0.000520\end{array}$ & $\begin{array}{l}0.022 \\
0.020 \\
0.017 \\
0.016\end{array}$ & $\begin{array}{l}0.001655 \\
0.002785 \\
0.004504 \\
0.005502\end{array}$ & $\begin{array}{l}-0.018 \\
-0.033 \\
-0.071 \\
-0.167\end{array}$ \\
\hline & 3 & $\begin{array}{c}1 / 16 \\
1 / 8 \\
1 / 4 \\
3 / 8\end{array}$ & $\begin{array}{l}-0.140260 \\
-0.129930 \\
-0.095740 \\
-0.048960\end{array}$ & $\begin{array}{l}-0.137730 \\
-0.130880 \\
-0.102450 \\
-0.059790\end{array}$ & $\begin{array}{l}0.982 \\
1.007 \\
1.070 \\
1.221\end{array}$ & $\begin{array}{r}-0.006580 \\
-0.005590 \\
-0.003610 \\
-0.001620\end{array}$ & $\begin{array}{l}0.047 \\
0.043 \\
0.038 \\
0.033\end{array}$ & $\begin{array}{l}0.004052 \\
0.006546 \\
0.010315 \\
0.012459\end{array}$ & $\begin{array}{l}-0.029 \\
-0.050 \\
-0.108 \\
-0.254\end{array}$ \\
\hline 0.5 & 1 & $\begin{array}{c}1 / 16 \\
1 / 8 \\
1 / 4 \\
3 / 8\end{array}$ & $\begin{array}{l}-0.077150 \\
-0.071640 \\
-0.053070 \\
-0.027450\end{array}$ & $\begin{array}{l}-0.076120 \\
-0.071820 \\
-0.055250 \\
-0.031080\end{array}$ & $\begin{array}{l}0.987 \\
1.002 \\
1.041 \\
1.132\end{array}$ & $\begin{array}{l}-0.002270 \\
-0.001940 \\
-0.001270 \\
-0.000600\end{array}$ & $\begin{array}{l}0.029 \\
0.027 \\
0.024 \\
0.022\end{array}$ & $\begin{array}{l}0.001237 \\
0.002114 \\
0.003449 \\
0.004228\end{array}$ & $\begin{array}{l}-0.016 \\
-0.030 \\
-0.065 \\
-0.154\end{array}$ \\
\hline & 2 & $\begin{array}{l}1 / 16 \\
1 / 8 \\
1 / 4 \\
3 / 8\end{array}$ & $\begin{array}{l}-0.165150 \\
-0.151720 \\
-0.110050 \\
-0.054670\end{array}$ & $\begin{array}{l}-0.153210 \\
-0.145850 \\
-0.114650 \\
-0.067500\end{array}$ & $\begin{array}{l}0.928 \\
0.961 \\
1.042 \\
1.235\end{array}$ & $\begin{array}{l}-0.017640 \\
-0.014970 \\
-0.009620 \\
-0.004270\end{array}$ & $\begin{array}{l}0.107 \\
0.099 \\
0.087 \\
0.078\end{array}$ & $\begin{array}{l}0.005700 \\
0.009094 \\
0.014212 \\
0.017103\end{array}$ & $\begin{array}{l}-0.035 \\
-0.060 \\
-0.129 \\
-0.313\end{array}$ \\
\hline & 3 & $\begin{array}{l}1 / 16 \\
1 / 8 \\
1 / 4 \\
3 / 8\end{array}$ & $\begin{array}{r}-0.274123 \\
-0.248590 \\
-0.175730 \\
-0.082880\end{array}$ & $\begin{array}{l}-0.230867 \\
-0.221740 \\
-0.177950 \\
-0.109150\end{array}$ & $\begin{array}{l}0.842 \\
0.892 \\
1.013 \\
1.317\end{array}$ & $\begin{array}{l}-0.057720 \\
-0.048690 \\
-0.030650 \\
-0.012600\end{array}$ & $\begin{array}{l}0.211 \\
0.196 \\
0.174 \\
0.152\end{array}$ & $\begin{array}{l}0.014464 \\
0.021848 \\
0.032859 \\
0.038860\end{array}$ & $\begin{array}{l}-0.053 \\
-0.088 \\
-0.187 \\
-0.469\end{array}$ \\
\hline 0.7 & 1 & $\begin{array}{l}1 / 16 \\
1 / 8 \\
1 / 4 \\
3 / 8\end{array}$ & $\begin{array}{l}-0.121500 \\
-0.111200 \\
-0.080260 \\
-0.039750\end{array}$ & $\begin{array}{l}-0.106860 \\
-0.101180 \\
-0.078520 \\
-0.045010\end{array}$ & $\begin{array}{l}0.880 \\
0.910 \\
0.978 \\
1.132\end{array}$ & $\begin{array}{l}-0.017660 \\
-0.015030 \\
-0.009770 \\
-0.004520\end{array}$ & $\begin{array}{l}0.145 \\
0.135 \\
0.122 \\
0.114\end{array}$ & $\begin{array}{l}0.003021 \\
0.005011 \\
0.008032 \\
0.009773\end{array}$ & $\begin{array}{l}-0.025 \\
-0.045 \\
-0.100 \\
-0.246\end{array}$ \\
\hline & 2 & $\begin{array}{l}1 / 16 \\
1 / 8 \\
1 / 4 \\
3 / 8\end{array}$ & $\begin{array}{l}-0.336190 \\
-0.298680 \\
-0.203820 \\
-0.090940\end{array}$ & $\begin{array}{l}-0.215310 \\
-0.206430 \\
-0.164990 \\
-0.100410\end{array}$ & $\begin{array}{l}0.640 \\
0.691 \\
0.809 \\
1.104\end{array}$ & $\begin{array}{l}-0.135340 \\
-0.114310 \\
-0.072250 \\
-0.030200\end{array}$ & $\begin{array}{l}0.403 \\
0.383 \\
0.355 \\
0.332\end{array}$ & $\begin{array}{l}0.014458 \\
0.022060 \\
0.033421 \\
0.039661\end{array}$ & $\begin{array}{l}-0.043 \\
-0.074 \\
-0.164 \\
-0.436\end{array}$ \\
\hline & 3 & $\begin{array}{l}1 / 16 \\
1 / 8 \\
1 / 4 \\
3 / 8\end{array}$ & $\begin{array}{l}-0.723310 \\
-0.626590 \\
-0.404660 \\
-0.157410\end{array}$ & $\begin{array}{l}-0.324200 \\
-0.314750 \\
-0.258700 \\
-0.165800\end{array}$ & $\begin{array}{l}0.448 \\
0.502 \\
0.639 \\
1.053\end{array}$ & $\begin{array}{l}-0.436760 \\
-0.365780 \\
-0.223840 \\
-0.081890\end{array}$ & $\begin{array}{l}0.604 \\
0.584 \\
0.553 \\
0.520\end{array}$ & $\begin{array}{l}0.037646 \\
0.053937 \\
0.077876 \\
0.090289\end{array}$ & $\begin{array}{l}-0.052 \\
-0.086 \\
-0.192 \\
-0.574\end{array}$ \\
\hline
\end{tabular}


Table B5. Case study for deflections across the opening for the $\mathrm{W} 18 \times 35$ section neglecting shear deformations

\begin{tabular}{|c|c|c|c|c|c|c|c|c|c|}
\hline \multirow[b]{2}{*}{$\frac{\mathrm{h}_{\mathrm{o}}}{\mathrm{d}}$} & \multirow[b]{2}{*}{$\frac{\mathrm{a}_{0}}{\mathrm{~h}_{0}}$} & \multirow[b]{2}{*}{$\frac{L_{0}}{L_{s}}$} & \multirow{2}{*}{$\frac{\begin{array}{c}\text { total } \\
\text { deflection }\end{array}}{\Delta_{y, b}}$} & \multicolumn{2}{|c|}{$\begin{array}{l}\text { deflection due to } \\
\text { rotation, } \theta\end{array}$} & \multicolumn{2}{|c|}{$\begin{array}{l}\text { deflection due to } \\
\text { shear load, P }\end{array}$} & \multicolumn{2}{|c|}{$\begin{array}{c}\text { deflection due to } \\
\text { moment, } M\end{array}$} \\
\hline & & & & $\Delta_{y}^{(\theta)}$ & $\frac{\Delta_{y}^{(\theta)}}{\Delta_{y, b}}$ & $\Delta_{y, b}^{(P)}$ & $\frac{\Delta_{y, b}^{(P)}}{\Delta_{y, b}}$ & $\Delta_{y, b}^{(M)}$ & $\frac{\Delta_{y, b}^{(M)}}{\Delta_{y, b}}$ \\
\hline 0.3 & 1 & $\begin{array}{l}1 / 16 \\
1 / 8 \\
1 / 4 \\
3 / 8\end{array}$ & $\begin{array}{l}-0.036280 \\
-0.033830 \\
-0.025280 \\
-0.013300\end{array}$ & $\begin{array}{l}-0.036380 \\
-0.034200 \\
-0.026070 \\
-0.014360\end{array}$ & $\begin{array}{l}1.003 \\
1.011 \\
1.031 \\
1.080\end{array}$ & $\begin{array}{l}-0.000210 \\
-0.000180 \\
-0.000120 \\
-0.000056\end{array}$ & $\begin{array}{l}0.006 \\
0.005 \\
0.005 \\
0.004\end{array}$ & $\begin{array}{l}0.000309 \\
0.000545 \\
0.000908 \\
0.001121\end{array}$ & $\begin{array}{l}-0.009 \\
-0.016 \\
-0.036 \\
-0.084\end{array}$ \\
\hline & 2 & $\begin{array}{l}1 / 16 \\
1 / 8 \\
1 / 4 \\
3 / 8\end{array}$ & $\begin{array}{l}-0.073350 \\
-0.068160 \\
-0.050530 \\
-0.026150\end{array}$ & $\begin{array}{r}-0.073080 \\
-0.069060 \\
-0.053330 \\
-0.030240\end{array}$ & $\begin{array}{l}0.996 \\
1.013 \\
1.055 \\
1.157\end{array}$ & $\begin{array}{l}-0.001620 \\
-0.001380 \\
-0.000900 \\
-0.000420\end{array}$ & $\begin{array}{l}0.022 \\
0.020 \\
0.018 \\
0.016\end{array}$ & $\begin{array}{l}0.001354 \\
0.002283 \\
0.003697 \\
0.004517\end{array}$ & $\begin{array}{l}-0.018 \\
-0.034 \\
-0.073 \\
-0.173\end{array}$ \\
\hline & 3 & $\begin{array}{l}1 / 16 \\
1 / 8 \\
1 / 4 \\
3 / 8\end{array}$ & $\begin{array}{l}-0.062130 \\
-0.103730 \\
-0.076220 \\
-0.038720\end{array}$ & $\begin{array}{l}-0.069160 \\
-0.104530 \\
-0.081740 \\
-0.047620\end{array}$ & $\begin{array}{l}1.113 \\
1.008 \\
1.072 \\
1.230\end{array}$ & $\begin{array}{l}-0.002300 \\
-0.004560 \\
-0.002950 \\
-0.001330\end{array}$ & $\begin{array}{l}0.037 \\
0.044 \\
0.039 \\
0.034\end{array}$ & $\begin{array}{l}0.009331 \\
0.005362 \\
0.008464 \\
0.010231\end{array}$ & $\begin{array}{l}-0.150 \\
-0.052 \\
-0.111 \\
-0.264\end{array}$ \\
\hline 0.5 & 1 & $\begin{array}{l}1 / 16 \\
1 / 8 \\
1 / 4 \\
3 / 8\end{array}$ & $\begin{array}{l}-0.061610 \\
-0.057180 \\
-0.042290 \\
-0.021800\end{array}$ & $\begin{array}{l}-0.060820 \\
-0.057370 \\
-0.044110 \\
-0.024780\end{array}$ & $\begin{array}{l}0.987 \\
1.003 \\
1.043 \\
1.137\end{array}$ & $\begin{array}{l}-0.001800 \\
-0.001530 \\
-0.001000 \\
-0.000480\end{array}$ & $\begin{array}{l}0.029 \\
0.027 \\
0.024 \\
0.022\end{array}$ & $\begin{array}{l}0.001010 \\
0.001728 \\
0.002823 \\
0.003462\end{array}$ & $\begin{array}{l}-0.016 \\
-0.030 \\
-0.067 \\
-0.159\end{array}$ \\
\hline & 2 & $\begin{array}{l}1 / 16 \\
1 / 8 \\
1 / 4 \\
3 / 8\end{array}$ & $\begin{array}{l}-0.131730 \\
-0.120900 \\
-0.087460 \\
-0.043140\end{array}$ & $\begin{array}{r}-0.122400 \\
-0.116470 \\
-0.091460 \\
-0.053740\end{array}$ & $\begin{array}{l}0.929 \\
0.963 \\
1.046 \\
1.246\end{array}$ & $\begin{array}{l}-0.013960 \\
-0.011850 \\
-0.007620 \\
-0.003400\end{array}$ & $\begin{array}{l}0.106 \\
0.098 \\
0.087 \\
0.079\end{array}$ & $\begin{array}{l}0.004640 \\
0.007424 \\
0.011625 \\
0.014002\end{array}$ & $\begin{array}{l}-0.035 \\
-0.061 \\
-0.133 \\
-0.325\end{array}$ \\
\hline & 3 & $\begin{array}{l}1 / 16 \\
1 / 8 \\
1 / 4 \\
3 / 8\end{array}$ & $\begin{array}{r}-0.218420 \\
-0.197820 \\
-0.139330 \\
-0.065030\end{array}$ & $\begin{array}{l}-0.184450 \\
-0.177040 \\
-0.141870 \\
-0.086780\end{array}$ & $\begin{array}{l}0.844 \\
0.895 \\
1.018 \\
1.334\end{array}$ & $\begin{array}{r}-0.045720 \\
-0.038590 \\
-0.024320 \\
-0.010060\end{array}$ & $\begin{array}{l}0.209 \\
0.195 \\
0.175 \\
0.155\end{array}$ & $\begin{array}{l}0.011753 \\
0.017816 \\
0.026864 \\
0.031809\end{array}$ & $\begin{array}{l}-0.054 \\
-0.090 \\
-0.193 \\
-0.489\end{array}$ \\
\hline 0.7 & 1 & $\begin{array}{l}1 / 16 \\
1 / 8 \\
1 / 4 \\
3 / 8\end{array}$ & $\begin{array}{l}-0.097430 \\
-0.089140 \\
-0.064280 \\
-0.031790\end{array}$ & $\begin{array}{r}-0.085380 \\
-0.080820 \\
-0.062670 \\
-0.035870\end{array}$ & $\begin{array}{l}0.876 \\
0.907 \\
0.975 \\
1.128\end{array}$ & $\begin{array}{l}-0.014450 \\
-0.012300 \\
-0.008000 \\
-0.003710\end{array}$ & $\begin{array}{l}0.148 \\
0.138 \\
0.125 \\
0.117\end{array}$ & $\begin{array}{l}0.002396 \\
0.003984 \\
0.006395 \\
0.007786\end{array}$ & $\begin{array}{l}-0.025 \\
-0.045 \\
-0.099 \\
-0.245\end{array}$ \\
\hline & 2 & $\begin{array}{l}1 / 16 \\
1 / 8 \\
1 / 4 \\
3 / 8\end{array}$ & $\begin{array}{l}-0.271450 \\
-0.240990 \\
-0.164260 \\
-0.072910\end{array}$ & $\begin{array}{l}-0.172020 \\
-0.164830 \\
-0.131550 \\
-0.079580\end{array}$ & $\begin{array}{l}0.634 \\
0.684 \\
0.801 \\
1.092\end{array}$ & $\begin{array}{l}-0.110870 \\
-0.093680 \\
-0.059300 \\
-0.024910\end{array}$ & $\begin{array}{l}0.408 \\
0.389 \\
0.361 \\
0.342\end{array}$ & $\begin{array}{l}0.011435 \\
0.017507 \\
0.026590 \\
0.031590\end{array}$ & $\begin{array}{l}-0.042 \\
-0.073 \\
-0.162 \\
-0.433\end{array}$ \\
\hline & 3 & $\begin{array}{l}1 / 16 \\
1 / 8 \\
1 / 4 \\
3 / 8\end{array}$ & $\begin{array}{l}-0.587529 \\
-0.508699 \\
-0.328344 \\
-0.127853\end{array}$ & $\begin{array}{r}-0.259047 \\
-0.251265 \\
-0.206116 \\
-0.131646\end{array}$ & $\begin{array}{l}0.441 \\
0.494 \\
0.628 \\
1.030\end{array}$ & $\begin{array}{r}-0.358201 \\
-0.300183 \\
-0.184148 \\
-0.068113\end{array}$ & $\begin{array}{l}0.610 \\
0.590 \\
0.561 \\
0.533\end{array}$ & $\begin{array}{l}0.029719 \\
0.042749 \\
0.061921 \\
0.071906\end{array}$ & $\begin{array}{l}-0.051 \\
-0.084 \\
-0.189 \\
-0.562\end{array}$ \\
\hline
\end{tabular}


Table B6. Case study for deflections across the opening for the W $14 \times 22$ section neglecting shear deformations

\begin{tabular}{|c|c|c|c|c|c|c|c|c|c|}
\hline \multirow[b]{2}{*}{$\frac{h_{0}}{d}$} & \multirow[b]{2}{*}{$\frac{a_{0}}{h_{0}}$} & \multirow[b]{2}{*}{$\frac{\mathrm{L}_{0}}{\mathrm{~L}_{\mathrm{s}}}$} & \multirow{2}{*}{$\frac{\begin{array}{c}\text { total } \\
\text { deflection }\end{array}}{\Delta_{\mathrm{y}, \mathrm{b}}}$} & \multicolumn{2}{|c|}{$\begin{array}{l}\text { deflection due to } \\
\text { rotation, } \theta\end{array}$} & \multicolumn{2}{|c|}{$\begin{array}{l}\text { deflection due to } \\
\text { shear load, P }\end{array}$} & \multicolumn{2}{|c|}{$\begin{array}{l}\text { deflection due to } \\
\text { moment, } \mathrm{M}\end{array}$} \\
\hline & & & & $\Delta_{y}^{(\theta)}$ & $\frac{\Delta_{y}^{(0)}}{\Delta_{y, b}}$ & $\Delta_{,, b}^{(P)}$ & $\frac{\Delta_{y, b}^{(\mathcal{P})}}{\Delta_{y, b}}$ & $\Delta_{y, b}^{(M)}$ & $\frac{\left.\Delta_{y, b}^{M}\right)}{\Delta_{y, b}}$ \\
\hline 0.3 & 1 & $\begin{array}{c}1 / 16 \\
1 / 8 \\
1 / 4 \\
3 / 8\end{array}$ & $\begin{array}{l}-0.022050 \\
-0.020540 \\
-0.015320 \\
-0.008020\end{array}$ & $\begin{array}{l}-0.022120 \\
-0.020800 \\
-0.015880 \\
-0.008780\end{array}$ & $\begin{array}{l}1.003 \\
1.012 \\
1.037 \\
1.095\end{array}$ & $\begin{array}{l}-0.000160 \\
-0.000140 \\
-0.000089 \\
-0.000043\end{array}$ & $\begin{array}{l}0.007 \\
0.007 \\
0.006 \\
0.005\end{array}$ & $\begin{array}{l}0.000223 \\
0.000392 \\
0.000651 \\
0.000803\end{array}$ & $\begin{array}{l}-0.010 \\
-0.019 \\
-0.042 \\
-0.100\end{array}$ \\
\hline & 2 & $\begin{array}{l}1 / 16 \\
1 / 8 \\
1 / 4 \\
3 / 8\end{array}$ & $\begin{array}{l}-0.044700 \\
-0.041450 \\
-0.030590 \\
-0.015660\end{array}$ & $\begin{array}{l}-0.044440 \\
-0.042040 \\
-0.032560 \\
-0.018570\end{array}$ & $\begin{array}{l}0.994 \\
1.014 \\
1.064 \\
1.186\end{array}$ & $\begin{array}{r}-0.001250 \\
-0.001060 \\
-0.000690 \\
-0.000320\end{array}$ & $\begin{array}{l}0.028 \\
0.026 \\
0.023 \\
0.021\end{array}$ & $\begin{array}{l}0.000987 \\
0.001650 \\
0.002656 \\
0.003238\end{array}$ & $\begin{array}{l}-0.022 \\
-0.040 \\
-0.087 \\
-0.207\end{array}$ \\
\hline & 3 & $\begin{array}{l}1 / 16 \\
1 / 8 \\
1 / 4 \\
3 / 8\end{array}$ & $\begin{array}{l}-0.068620 \\
-0.063300 \\
-0.046170 \\
-0.023040\end{array}$ & $\begin{array}{l}-0.066930 \\
-0.063680 \\
-0.050000 \\
-0.029380\end{array}$ & $\begin{array}{l}0.975 \\
1.006 \\
1.083 \\
1.275\end{array}$ & $\begin{array}{l}-0.004130 \\
-0.003500 \\
-0.002250 \\
-0.001000\end{array}$ & $\begin{array}{l}0.060 \\
0.055 \\
0.049 \\
0.044\end{array}$ & $\begin{array}{l}0.002430 \\
0.003889 \\
0.006091 \\
0.007337\end{array}$ & $\begin{array}{l}-0.035 \\
-0.061 \\
-0.132 \\
-0.318\end{array}$ \\
\hline 0.5 & 1 & $\begin{array}{l}1 / 16 \\
1 / 8 \\
1 / 4 \\
3 / 8\end{array}$ & $\begin{array}{l}-0.037620 \\
-0.034850 \\
-0.025660 \\
-0.013090\end{array}$ & $\begin{array}{l}-0.036980 \\
-0.034910 \\
-0.026910 \\
-0.015200\end{array}$ & $\begin{array}{l}0.983 \\
1.002 \\
1.049 \\
1.161\end{array}$ & $\begin{array}{r}-0.001370 \\
-0.001170 \\
-0.000770 \\
-0.000360\end{array}$ & $\begin{array}{l}0.036 \\
0.034 \\
0.030 \\
0.028\end{array}$ & $\begin{array}{l}0.000729 \\
0.001238 \\
0.002012 \\
0.002463\end{array}$ & $\begin{array}{l}-0.019 \\
-0.036 \\
-0.078 \\
-0.188\end{array}$ \\
\hline & 2 & $\begin{array}{l}1 / 16 \\
1 / 8 \\
1 / 4 \\
3 / 8\end{array}$ & $\begin{array}{l}-0.081690 \\
-0.074630 \\
-0.053450 \\
-0.025760\end{array}$ & $\begin{array}{l}-0.074450 \\
-0.070980 \\
-0.055990 \\
-0.033200\end{array}$ & $\begin{array}{l}0.911 \\
0.951 \\
1.048 \\
1.289\end{array}$ & $\begin{array}{l}-0.010620 \\
-0.009000 \\
-0.005770 \\
-0.002530\end{array}$ & $\begin{array}{l}0.130 \\
0.121 \\
0.108 \\
0.098\end{array}$ & $\begin{array}{l}0.003388 \\
0.005352 \\
0.008309 \\
0.009970\end{array}$ & $\begin{array}{l}-0.041 \\
-0.072 \\
-0.155 \\
-0.387\end{array}$ \\
\hline & 3 & $\begin{array}{l}1 / 16 \\
1 / 8 \\
1 / 4 \\
3 / 8\end{array}$ & $\begin{array}{l}-0.138200 \\
-0.124280 \\
-0.086130 \\
-0.038620\end{array}$ & $\begin{array}{l}-0.112180 \\
-0.107990 \\
-0.087100 \\
-0.053930\end{array}$ & $\begin{array}{l}0.812 \\
0.869 \\
1.011 \\
1.397\end{array}$ & $\begin{array}{l}-0.034660 \\
-0.029200 \\
-0.018280 \\
-0.007350\end{array}$ & $\begin{array}{l}0.251 \\
0.235 \\
0.212 \\
0.190\end{array}$ & $\begin{array}{l}0.008649 \\
0.012910 \\
0.019245 \\
0.022664\end{array}$ & $\begin{array}{l}-0.063 \\
-0.104 \\
-0.223 \\
-0.587\end{array}$ \\
\hline 0.7 & 1 & $\begin{array}{l}1 / 16 \\
1 / 8 \\
1 / 4 \\
3 / 8\end{array}$ & $\begin{array}{l}-0.061880 \\
-0.056330 \\
-0.040250 \\
-0.019580\end{array}$ & $\begin{array}{l}-0.051920 \\
-0.049210 \\
-0.038290 \\
-0.022060\end{array}$ & $\begin{array}{l}0.839 \\
0.874 \\
0.951 \\
1.127\end{array}$ & $\begin{array}{l}-0.011660 \\
-0.009920 \\
-0.006440 \\
-0.002950\end{array}$ & $\begin{array}{l}0.188 \\
0.176 \\
0.160 \\
0.151\end{array}$ & $\begin{array}{l}0.001706 \\
0.002808 \\
0.004478 \\
0.005437\end{array}$ & $\begin{array}{l}-0.028 \\
-0.050 \\
-0.111 \\
-0.278\end{array}$ \\
\hline & 2 & $\begin{array}{c}1 / 16 \\
1 / 8 \\
1 / 4 \\
3 / 8\end{array}$ & $\begin{array}{r}-0.185440 \\
-0.163200 \\
-0.109280 \\
-0.046850\end{array}$ & $\begin{array}{l}-0.104630 \\
-0.100520 \\
-0.080720 \\
-0.049570\end{array}$ & $\begin{array}{l}0.564 \\
0.616 \\
0.739 \\
1.058\end{array}$ & $\begin{array}{l}-0.089060 \\
-0.075120 \\
-0.047240 \\
-0.019370\end{array}$ & $\begin{array}{l}0.480 \\
0.460 \\
0.432 \\
0.413\end{array}$ & $\begin{array}{l}0.008246 \\
0.012436 \\
0.018683 \\
0.022083\end{array}$ & $\begin{array}{l}-0.044 \\
-0.076 \\
-0.171 \\
-0.471\end{array}$ \\
\hline & 3 & $\begin{array}{l}1 / 16 \\
1 / 8 \\
1 / 4 \\
3 / 8\end{array}$ & $\begin{array}{l}-0.422070 \\
-0.361970 \\
-0.228360 \\
-0.083000\end{array}$ & $\begin{array}{l}-0.157470 \\
-0.153350 \\
-0.126900 \\
-0.08230\end{array}$ & $\begin{array}{l}0.373 \\
0.424 \\
0.556 \\
0.992\end{array}$ & $\begin{array}{l}-0.286200 \\
-0.239160 \\
-0.145080 \\
-0.050990\end{array}$ & $\begin{array}{l}0.678 \\
0.661 \\
0.635 \\
0.614\end{array}$ & $\begin{array}{l}0.021601 \\
0.030541 \\
0.043618 \\
0.050291\end{array}$ & $\begin{array}{l}-0.051 \\
-0.084 \\
-0.191 \\
-0.606\end{array}$ \\
\hline
\end{tabular}




\section{APPENDIX C}

\section{NOMENCLATURE}

A

$A_{b}$

$\mathrm{A}_{\mathrm{s}}$

$A_{t}$

$\mathrm{A}_{\mathrm{y}}$

$A_{y, b}$

$A_{y, t}$

E

$\mathrm{F}_{\mathrm{y}}$

G

I

$\mathrm{I}_{\mathrm{b}}$

$\mathrm{I}_{\text {eff }}$

$\mathrm{I}_{\text {eq }}$

$I_{g}$

$I_{1 b}$

$I_{s}$

$I_{\mathrm{s}}$

$\mathrm{I}_{\mathrm{t} 1}$

$I_{12}$

$\mathrm{I}_{\mathrm{tr}}$

$I_{\text {wo }}$

$[\mathrm{K}]_{\mathrm{e}}$

$[\mathrm{K}]_{\mathrm{g}}$

$[\mathrm{K}]_{\mathrm{wo}}$

L

$\mathrm{L}_{\mathrm{o}}$

Cross-sectional area, in?

Cross-sectional area for the bottom tee, in.

Cross-sectional area of steel, in?

Cross-sectional area for the top tee, in.

Effective shear area, in.

Effective shear area for the bottom tee, in.

Effective shear area for the top tee, in?

Modulus of elasticity of steel $(29,000 \mathrm{ksi}$.

Yield stress of steel, ksi.

Shear modulus of elasticity of steel $(11,150 \mathrm{ksi}$.

Moment of inertia, in.

Moment of inertia for the bottom tee, in.

Effective moment of inertia of composite sections, in.

Equivalent moment of inertia for the top tee, in.

Gross moment of inertia of the composite beam, in.

Lower bound moment of inertia for composite sections, in.

Moment of inertia of steel section, in.

Moment of inertia for the top tee, in.

Moment of inertia for the top tee at the low moment end of an opening, in.

Moment of inertia for the top tee at the high moment end, in.

Moment of inertia of transformed composite section, in.

Moment of inertia of the section at a web opening, in.

Local element stiffness matrix

Global element stiffness matrix

Global stiffness matrix for the web opening element

Length of an element

Location of opening center line 


\begin{tabular}{|c|c|}
\hline $\mathrm{L}_{\mathrm{s}}$ & Span length \\
\hline$P$ & Shear force \\
\hline$Q_{n}$ & Nominal strength of one stud shear connector, kips. \\
\hline$V_{h}$ & $\begin{array}{l}\text { Total horizontal shear to be resisted by connectors under full composite } \\
\text { action, kips. }\end{array}$ \\
\hline $\mathrm{V}_{\mathrm{h}}^{\prime}$ & $\begin{array}{l}\text { Total horizontal shear provided by the connectors in providing partial } \\
\text { composite action, kips. }\end{array}$ \\
\hline $\mathrm{Y}_{\mathrm{ENA}}$ & Distance from bottom of beam to elastic neutral axis, in. \\
\hline$Y_{2}$ & $\begin{array}{l}\text { Distance from concrete flange force to beam top flange in a composite } \\
\text { beam, in. }\end{array}$ \\
\hline$a_{0}$ & Opening length \\
\hline$e_{x 1}$ & Local $x$ eccentricity at node 1 at an opening \\
\hline$e_{x 2}$ & Local $x$ eccentricity at node 2 at an opening \\
\hline$e_{y 1}$ & Local y eccentricity at node 1 at an opening \\
\hline$e_{\mathrm{y} 2}$ & Local y eccentricity at node 2 at an opening \\
\hline$f_{c}^{\prime}$ & Concrete compressive strength, psi \\
\hline$h_{0}$ & Height of opening \\
\hline$l_{b}$ & Length of rigid link for the bottom tee \\
\hline$l_{t}$ & Length of rigid link for the top tee \\
\hline$\{u\}_{1}$ & Element local displacements \\
\hline$\{u\}_{g}$ & Global displacements \\
\hline w & Uniform load \\
\hline \multirow{2}{*}{$\beta$} & I \\
\hline & {$\left[\left(\mathrm{L}^{2} / 12\right)+\eta\right]$} \\
\hline \multirow{2}{*}{$\beta_{b}$} & $I_{b}$ \\
\hline & {$\left[\left(\mathrm{a}_{\alpha}^{2} / 12\right)+\eta_{\mathrm{b}}\right]$} \\
\hline \multirow{2}{*}{$\beta_{\text {eq }}$} & $8 \mathrm{I}_{\mathrm{eq}}$ \\
\hline & {$\left[\left(\mathrm{a}^{2} / 12\right)+\eta_{\mathrm{eq}}\right]$} \\
\hline$\Delta$ & Deflection \\
\hline$\Delta_{\mathrm{b}}$ & Maximum deflection due to bending \\
\hline
\end{tabular}


$\Delta_{\mathrm{m}} \quad$ Maximum deflection for a beam with a web opening

$\Delta_{\mathrm{m}, \mathrm{b}} \quad$ Maximum bending deflection for a beam with a web opening

$\Delta_{s} \quad$ Maximum deflection due to shear deformations

$\Delta_{\mathrm{y}} \quad$ Vertical deflection across a web opening

$\Delta_{\mathrm{y}}^{(\mathrm{M})} \quad$ Deflection across a web opening due to moment $\mathrm{M}$

$\Delta_{\mathrm{y}, \mathrm{b}}^{(\mathrm{M})} \quad$ Bending deflection across a web opening due to moment $\mathrm{M}$

$\Delta_{y, s}^{(M)} \quad$ Shear deflection across a web opening due to moment $M$

$\Delta_{y}^{(P)} \quad$ Deflection across a web opening due to shear force $P$

$\Delta_{\mathrm{y}, \mathrm{b}}^{(\mathrm{P})}$

$\Delta_{\mathrm{y}, \mathrm{s}}^{(\mathrm{P})}$

Bending deflection across a web opening due to shear force $\mathrm{P}$

Shear deflection across a web opening due to shear force $P$

$\Delta_{y}^{(\theta)}$

Deflection across a web opening due to rigid body rotation at the low moment end

$\frac{E I}{A_{y} G}$

$\eta_{\mathrm{b}}$

$\frac{E_{b}}{A_{y b} G}$

$\eta_{\text {eq }}$

$\frac{8 \mathrm{EI}_{\mathrm{eq}}}{\mathrm{A}_{\mathrm{yt}} \mathrm{G}}$

$\lambda$

$\frac{\beta_{\mathrm{eq}}}{\beta_{\mathrm{eq}}+\beta_{\mathrm{b}}}$

Rotation at low moment end of web opening 